\title{
A Nimród fehérje- és géncsalád szerepe a mikroorganizmusok felismerésében és bekebelezésében
}

PhD értekezés

Szerző:

Zsámboki János

Témavezetö:

Dr. Kurucz Éva

Biológia doktori iskola

MTA Szegedi Biológiai Kutatóközpont

Genetikai Intézet

SZTE TTIK

2013

Szeged 


\section{Tartalomjegyzék}

Rövidítések jegyzéke

3. old

1. Bevezetés

4. old

1.1 A Drosophila melanogaster immunvédekezése

4. old

1.2 A NimC1 fehérje doménszerkezete és a nimród géncsalád

10. old

2. Célkitüzések

15. old

3. Anyagok és módszerek

16. old

3.1 Anyagok

16. old

3.2 Módszerek

19. old

4. Eredmények

30. old

4.1 A P1 molekula azonosítása

30. old

4.2 A NimC1 fehérjét kódoló nimC1 gén azonosítása

31. old

4.3 A nimród géncsalád tagjainak transzkripciója

33. old

4.4 A NimC1 szerepe a fagocitózisban

37. old

4.5 A natív, hemocitákból izolált NimC1 fehérje baktériumkötése

38. old

4.6 A NimC1 fehérje ligandjának vizsgálata

42. old

4.7 A rekombináns Nimród fehérjék baktériumkötése

44. old

5. Az eredmények megbeszélése

48. old

6. Köszönetnyilvánítás

53. old

7. Hivatkozott közlemények

54. old

8. Magyar nyelvü összefoglaló

60. old

9. Summary

63. old 


\section{Rövidítések jegyzéke}

APS: ammónium perszulfát

BSA: marha szérumból származó albumin fehérje

DAPI: 4,6-diamidin-2-fenilindol

DEPC: dietil-pirokarbonát

DMSO: dimetil-szulfoxid

EDTA: 2-[2-(Bisz(karboximetil)amino)etil-(carboximetil)amino]ecetsav

FACS: áramlási citometria (Fluorecence Activated Cell Sorting)

FITC: fluoreszcein izotiocianát

GFP: zöld fluoreszcens fehérje (Green Fluorescent Protein)

HEPES: 4-(2-hidroxietil)-1-piperazinetánszulfonsav

IPTG: izopropil-béta-D-thiogalaktopiranozid

KRPMI: 5\% marha szérummal kiegészített RPMI-1640 szövettenyésztő táptalaj (Roswell Park

Memorial Institute)

LB: Luria Bertani/Lysogenic Broth táptalaj

LDL: alacsony sürüségü lipoprotein (Low Density Lipoprotein)

LPS: lipopoliszaccharid

LTA: lipoteikolsav

MFI: a fluoreszcencia-intenzitások számtani közepe (Mean Fluorescence Intensity)

NP-40: Nonidet P-40 oktil fenoxipolietoxietanol

PG: peptidoglikán

PGRP: peptidoglican recognition protein

PRR: Mintázatfelismerő receptor (Pattern Recognition Receptor)

PTU: 1-fenil-2-tiourea

PVDF: poli-1,1 difluoretilén

RMFI: relatív fluoreszcencia intenzitás (a minta MFI és a kontroll MFI értékek hányadosa)

SDS: sodium dodecil sulphate

TEMED: tetrametiléndiamin

TRIS: 2-Amino-2-hidroximetil-propán-1,3-diol

X-Gal: 5-bromo-4-kloro-3-indolil- $\beta$-D-galaktopiranozid 


\section{Bevezetés}

\subsection{A Drosophila melanogaster immunvédekezése}

Az eukarióta szervezetekre állandó veszélyt jelentenek a környezetükben nagy mennyiségben élő mikroorganizmusok, ezért homeosztázisuk fenntartásához hatékony védekező rendszer szükséges. A többsejtü szervezetek első védelmi vonalát a veleszületett immunitás képezi, amely a csíravonalban kódolt elemeivel azonnali immunválasszal képes fellépni a mikróbák ellen. A Drosophila melanogaster, az ecetmuslica a veleszületett immunitás egyik széles körben használt modellszervezete, immunrendszerének effektor folyamatai a bekebelezés, az antimikróbiális peptidek termelése és a melanizált tok képzése (Lemaitre és Hoffmann, 2007).

Az ecetmuslica nyílt keringési rendszerrel rendelkezik, a hemolimfájában keringő vérsejtek, a hemociták az immunválasz effektor sejtjei. A hemocitákat három morfológiailag eltérő csoportba sorolhatjuk, a keringő vérsejtek kilencvenöt százalékát a kisméretü (8-10 $\mu \mathrm{m})$, kerek plazmatociták teszik ki. A plazmatociták a mikróbák és apoptotikus sejtek bekebelezésével, valamint antimikróbiális peptidek és extracelluláris mátrix fehérjék termelésével járulnak hozzá a szervezet homeosztázisának fenntartásához. A kristálysejtek a plazmatocitáknál nagyobb méretű (10-12 $\mu \mathrm{m})$ kerek sejtek, a keringő vérsejtek öt százalékát teszik ki, a citoplazmájukban a vérnyirok-alvadáshoz és a tokképzéshez szükséges melanin bioszintézisét végző profenoloxidáz enzim kristályait tartalmazzák. A hemociták harmadik típusába a nagyméretü (15-40 $\mu \mathrm{m})$, lapos lamellociták tartoznak, amelyek a parazitoid darázsfertőzést követően jelennek meg a keringésben és a parazita petéjének a felületére tapadva a pete körül kialakuló melanizált tok képzésében játszanak szerepet (Evans és mtsai., 2003; Williams, 2007).

A mikróbák elleni immunvédekezés fontos effektor folyamata a bekebelezés vagy fagocitózis, amely az eukariótákra általánosan jellemző ősi, az evolúció során konzervált mechanizmus. A bekebelezés az eukarióta egysejtüekben a táplálkozáshoz szükséges, a többsejtüekben az egyedfejlödés során a szövetek átrendeződésében valamint az immunvédekezésben játszik szerepet. A többsejtűekben a fagocita sejtek az apoptózissal elpusztuló saját sejteket és a szervezet homeosztázisát felborító mikróbákat kebelezik be. A fagocitózis első lépése a bekebelezendő részecske felismerése, melyet a csíravonalban kódolt receptorfehérjék végeznek. Mivel ezek a fagocitózis receptorok a mikroorganizmusokra közösen jellemző molekuláris mintázatot ismernek fel, mintázatfelismerő receptoroknak nevezzük őket. A 
mintázatfelismerő receptorok a mikróbák nagyobb rendszertani csoportjain megtalálható ligandjai lehetnek a lipopoliszaccharid, a peptidoglikán, vagy a lipoteikolsav, azaz egyetlen, csíravonalban kódolt receptorfehérje számos különböző mikróba felismerésére is képes.

A fagocitózis első lépése a bekebelezni kívánt mikróba felismerése és megkötése. A Drosophila melanogasterben számos különböző típusú fagocitózis receptort írtak le eddig (Stuart és Ezekowitz, 2005; Stuart és Ezekowitz, 2008): a scavenger-receptorokat (Stuart és mtsai., 2005), a teljes átalakulással fejlödő rovarokban széles körben elterjedt, egyetlen csíravonalban kódolt génről alternatív splicinggal nagy számú különböző receptorfehérjét kódoló messenger RNS-t átírni képes DSCAM fehérjéket (Watson és mtsai., 2005), az NPC2 domént tartalmazó receptorokat (Shi és mtsai., 2012), a PGRP-LC fehérjét (Werner és mtsai., 2000), a Tep fehérjéket (Boun Aun és mtsai., 2011), valamint az epidermal growth factor (EGF) doméneket tartalmazó receptorfehérjéket, az Eatert, a Drapert és a NimC4-et (Kocks és mtsai., 2005; Manaka és mtsai., 2004). Az ismert fagocitózis receptorok müködéséről szerzett ismereteink azonban sok szempontból hiányosak: számos génről csupán annyi adattal rendelkezünk, hogy Schneider-2 sejtvonalban végzett RNS inhibíció hatására csökken a sejtek fagocitáló képessége és sokszor a fehérjék biokémiai vizsgálatáról sincs adatunk. Számos fehérjecsaládnak csak egyetlen reprezentatív tagjáról rendelkezünk adatokkal és a hozzájuk hasonló fehérjék működése is gyakran ismeretlen.

A mintázatfelismerő receptorok egyik típusa a scavenger-receptorokhoz hasonló szerkezetü fehérjék. Az emlős scavenger receptorok közös tulajdonsága, hogy képesek acetilált vagy oxidált LDL ligandot kötni, de a fehérjecsalád számos tagja baktériumok vagy apoptotikus sejtek felismerésében játszik szerepet, ezek felületén általában több különböző, jellemezően polianionos ligandhoz kapcsolódnak (Peiser és mtsai., 2002). Az ecetmuslica genom több scavenger receptort is kódol, ám ezek funkcióiról keveset tudunk. A Drosophila Scavenger Receptor-CI (dSR-CI) módosított LDL-hez kötődik, valamint Gram-pozitív és Gram-negatív baktériumok fagocitálásában játszik szerepet. A dSR-CI fehérjét CHO sejtvonalban kifejeztetve, a hővel elölt E. coli és $S$. aureus baktériumok a sejtek felszínén aggregálódnak. Ez a baktériumkötés lipoteikolsavval gátolható, lipopoliszachariddal azonban nem. A dSR-CI transzkript mennyiségnek RNS inhibícióval történő csökkentése során a Schneider-2 sejtvonal sejtjeinek baktérium fagocitáló képessége ötödével csökken (Rämet és mtsai., 2001). A dSR-CI molekula D. melanogaster genomban kódolt további három doménszerkezeti homológjának (dSR-CII, dSR-CIII, dSR-CIV) funkcióját még nem ismerjük (Rämet és mtsai., 2001, Pearson és mtsa., 1995). 
$\mathrm{Az}$ emlősök B típusú scavenger receptoraihoz hasonló fehérjék is megtalálhatóak az ecetmuslicában. A D. melanogaster genomjában tizennégy, az emberi CD36 molekulához hasonló fehérjét kódoló gént azonosítottak (Herboso és mtsai., 2011). Ezek közül a Croquemort és a Peste fehérjék az emlős makrofágok scavenger receptorainak feladatát látják el az ecetmuslica hemocitáin. További négy CD36-hoz hasonló fehérjét kódoló gén, az emp, ninaD, santa-maria, SNMP szerepe ismert, ám ezek nem rendelkeznek immunfunkcióval (Voolstra és mtsai. 2006, Pak és mtsai., 2012, Jin és mtsai., 2008).

A Croquemort receptor ligandjai apoptotikus sejteken megnyilvánuló molekulák (Franc és mtsai., 1996, Franc és mtsai., 1999). A croquemort gén RNS inhibíciós csendesítése következtében csökken a sejtek $S$. aureus fagocitáló képessége, ám E. coli fagocitáló képességük nem változik. Ezen eredmények hatására vizsgálták meg az emberi CD36 receptort és fedezték fel, hogy az szerepet játszik az apoptotikus sejtek bekebelezésében. A HEK293 emberi sejtvonalban a CD36 fehérje kifejeztetése megnöveli a sejtek $E$. coli és $S$. aureus fagocitáló képességét, a CD36 fehérje hiánya viszont csökkenti az egér makrofágok $S$. aureus fagocitáló képességét (Stuart és mtsai., 2005).

A Peste receptor molekula a baktériumok bekebelezésében játszik szerepet. Megfigyelték, hogy a peste RNS mennyiségét csökkentő kettősszálú RNS konstrukttal kezelt Schneider-2 sejtek kisebb hatékonysággal kebelezik be a Mycobacterium fortutium baktériumokat, viszont a Peste fehérje nem játszik szerepet sem az E. coli, sem a S. aureus fagocitálásában. Az emberi HEK293 sejtvonalban kifejeztetett Peste fehérje megnöveli a sejtek $M$. fortutitum, valamint kis mértékben $E$. coli és $S$. aureus felvevő képességét (Philips és mtsai., 2005).

A Dscam molekulát eredetileg az idegrendszer fejlődésében szerepet játszó fehérjeként azonosították. A D. melanogaster Dscam fehérjét kódoló génről alternatív splicinggal elméletileg tizenkilencezer különböző fehérjét kódoló messenger RNS molekula képződhet. Erről a rendkívül változékonysággal rendelkező fehérjéről az is kiderült, hogy a baktériumok fagocitálásában szintén szerepet játszik. A Dscam fehérje a zsírtestben és a keringő hemocitákban is kifejeződik. A sejtmembránhoz kötött Dscam molekula mellett egy rövidebb méretü, a hemolimfában keringő Dscam izoformát is azonosítottak. A Dscam funkcióvesztéses mutánsok hemocitái kevesebb E. coli baktériumot fagocitálnak, mint a vad típusú hemociták. Áramlási citometriával azt is kimutatták, hogy az egyes Dscam izoformák különböző affinitással kötődnek E. coli baktériumokhoz (Watson és mtsai., 2005). 
A D. melanogaster genom több peptidoglikánt felismerö fehérjét (PGRP) kódoló gént tartalmaz, az általuk kódolt PGRP fehérjék közös jellemzője a róluk elnevezett PGRP domén (Werner és mtsai., 2000). A PGRP receptorok közül az PGRP-SA, PGRP-SD, PGRP-LE elsősorban a humorális immunválaszban játszik szerepet, a fagocitózis folyamatában a molekulacsalád egyetlen tagja, a PGRP-LC vesz részt. A PGRP-LC transzmembrán fehérje kifejeződésének RNS inhibíciós gátlása csökkenti a Schneider-2 sejtek E. coli fagocitáló képességét, míg a $S$. aureus bekebelezésére nincs hatással. PGRP-LC hiányában jelentősen csökken a Schneider-2 sejtek által immunindukció következtében termelődő antimikróbiális peptidek mennyisége. Immunindukció hatására a $P G R P-L C$ null mutáns ecetmuslica egyedekben jelentősen csökkent a Diptericin messenger RNS mennyisége és ez a mutáns muslicatörzs a vad típusúnál érzékenyebb az E. coli fertőzésre is (Rämet és mtsai., 2002).

A D. melanogaster genom öt olyan gént tartalmaz, amely az állatvilágban erősen konzervált a2Macroglobulin fehérjecsaládba tartozó Tep (thioester-contining protein) fehérjét kódol. A tep géncsalád tagjai harmadik stádiumú lárvákban immunindukció nélkül a lymph glandben (tepl, tep4), a plazmatocitákban (tep1, tep2, tep3, tep4, tep6), fejeződnek ki, ám E. coli és Micrococcus luteus baktériumok keverékével végzett immunindukció hatására a tep1, tep2 és tep4 gének a zsírtestben is kifejeződnek, míg a tep6 gén kifejeződése nem változik. Az Mcr/TepVI (macroglobulin complement related) mennyiségét RNS inhibícióval csökkentve Schneider-2 sejtekben csökken a sejtek C. albicans fagocitáló képessége, ám ezek a sejtek a kezeletlen Schneider-2 sejtekhez hasonlóan kebelezik be az E. coli baktériumokat és a gumigyöngyöket (Boun Aoun és mtsai., 2011). A különböző Tep fehérjék különböző mikróbák fagocitálásához szükségesek, a TepII fehérje RNS inhibíciós csendesítése hatására csökken a sejtek E. coli fagocitáló képessége, ám a $C$. albicans és $S$. aureus bekebelezése nem változik, míg a TepIII RNS inhibíciós csendesítése kizárólag a $S$. aureus fagocitózisát gátolja. Schneider-2 sejtek felülúszójával vad típusú $C$. albicans törzset kezelve, az Mcr fehérje Western blot elemzéssel kimutatható a $C$. albicans sejteken (Strochein-Stevenson és mtsai., 2006). Az E. coli, E. cloacae, S. pyogenes, S. aureus, Enterococcus facealis, Listeria monocytogenes és M. marinum baktériumfertőzést követően a tep1, tep2, tep3 és tep4 funkcióvesztéses mutánsok életképessége meglepő módon megegyezik a vad típussal illetve a tep1, tep2, tep4, tep6 funkcióvesztéses mutánsok a vad típusúhoz hasonló mértékben élték túl a Beauvoriana bassiana gombafertőzést. Ezek a megfigyelések arra utalnak, hogy a Tep fehérjék müködése redundáns, a mutáns fehérjék funkcióit a többi Tep fehérje képes helyettesíteni, az egyes tep gének funkcióvesztéses mutánsainak nincs mérhető fenotípusa (Boun Aoun és mtsai., 2011). 
A közelmúltban azonosítottak egy új típusú, ML (MD-2 related lipid recognition) domént tartalmazó fehérjecsaládot, amelyekből a D. melanogaster genomja nyolcat kódol, ezeket NPC2szerü fehérjéknek nevezik. Prokarióta expressziós rendszerben, E. coli baktériumban kifejeztetett rekombináns NPC2a, NPC2e és NPC2h fehérjék kötődnek lipopoliszaccharidhoz, Lipid A-hoz, peptidoglikánhoz és lipoteikolsavhoz (Shi és mtsai., 2012).

Az ecetmuslicában három epidermal growth factor (EGF) doméneket tartalmazó fagocitózis receptor ismerünk, a Draper-t, az Eater-t és a NimC4/Six microns under-t (Simu) (Ulvila és mtsai., 2011).

A Draper fehérjét elsőként apoptotikus sejtek receptoraként írták le. A draper messenger RNS mennyiségét az 1(2)mbn sejtvonalban RNS inhibíció módszerrel csökkentve, a sejtek apoptotikus sejt fagocitáló képessége csökkent, ám a gumigyöngy és a zymosan (élesztő sejtfal polimer) bekebelezése nem változott. D. melanogaster embriókban a draper messenger RNS-t in vivo RNS inhibícióval csendesítve, az embrionális makrofágok apoptotikus sejt fagocitáló képessége csökkent (Manaka és mtsai., 2004). Az apoptotikus sejtek felszínén a Draper receptor ligandja a Pretaporter fehérje, a pretaporter null mutánsokban a hemociták és a gliasejtek alacsonyabb hatékonysággal kebelezik be a az apoptotikus sejteket az idegrendszer területén (Kuraishi és mtsai., 2009). A draper messenger RNS mennyiségét RNS inhibícióval csökkentve, a hemociták E. coli és a S. epidermidis fagocitáló képessége is csökken (Cuttell és mtsai., 2008, Hashimoto és mtsai., 2009).

Az eater gén csendesítésének hatására a Schneider-2 sejtek E. coli és $S$. aureus fagocitáló képessége is csökken. Az eater null mutánsok hemocitái alacsonyabb hatékonysággal fagocitálják a S. marcescens és $S$. aureus baktériumokat, mint a vad típusú hemociták, ez a fenotípus menekíthető az Eater fehérje kifejeztetésével. Az Eater fehérje N-terminális 199 aminosavnyi szakaszát rekombináns fehérjeként kifejeztetve áramlási citometriával kimutatható az Eater fehérje $S$. marcescens baktériumsejtekhez való kötődése (Kocks és mtsai., 2005). Szintén áramlási citometriás mérésekkel látták be, hogy a rekombináns Eater fehérje kötődik hőinaktivált vagy etil-alkohollal inaktivált Gram-negatív E. coli, S. marcescens, Pseudomonas aeruginosa és Gram-pozitív Enterococcus faecalis, S. aureus baktériumokhoz, míg Micrococcus luteus baktériumokon és $C$. albicans gombákon nem mutattak ki Eater kötődést. A rekombináns Eater fehérje kötődik élő vagy formaldehiddel inaktivált E. faecalis és $S$. aureus baktériumokhoz, viszont nem kötődik élő vagy formaldehiddel inaktivált Gram-negatív E. coli, S. marcescens, P. aeruginosa baktériumokhoz (Chung és Kocks 2011a). A Cecropin A antimikróbiális peptiddel (Chung és Kocks 2011a) vagy lizozim enzimmel (Chung és Kocks 2011b) kezelt élő E. coli baktériumokat viszont köti az Eater 
molekula. Ennek a jelenségnek valószínüleg az a magyarázata, hogy az ép bakteriális membránon belül rejtve marad az Eater receptor ligandja és a membrán fellazítása szükséges ahhoz, hogy a ligand az Eater receptor számára hozzáférhetővé váljon (Nehme és mtsai., 2011).

A NimC4/Simu (Kurant és mtsai., 2008) fehérjéröl kimutatták, hogy a gliasejteken valamint az embrionális makrofágokon fejeződik ki és a központi idegrendszer érése során az apoptózissal elpusztuló sejtek fagocitózisában játszik szerepet. A NimC4 null mutánsa homozigóta életképes, fejlődési rendellenességgel nem rendelkezik, ám az embrionális idegrendszer fejlődése során ebben a mutánsban az apoptotikus sejtek eltakarítása késik (Kurant és mtsai., 2008).

\section{1. táblázat: A Drosophila melanogaster fagocitózis receptorok}

\begin{tabular}{|c|c|c|c|c|}
\hline Receptor & $\begin{array}{l}\text { Gram-negatív } \\
\text { baktérium }\end{array}$ & $\begin{array}{l}\text { Gram-pozitív } \\
\text { baktérium }\end{array}$ & gomba & apoptotikus sejt \\
\hline dSR-CI & + & + & NA & NA \\
\hline PGRP-LC & + & - & NA & NA \\
\hline MCR/TEP6 & - & NA & + & NA \\
\hline TEPII & + & - & - & NA \\
\hline TEPIII & - & + & - & NA \\
\hline Peste & + & + & NA & NA \\
\hline Croquemort & + & + & NA & + \\
\hline Dscam & + & NA & NA & NA \\
\hline $\mathrm{NPC} 2 \mathrm{a}, 2 \mathrm{e}, 2 \mathrm{~h}$ & $+?$ & $+?$ & NA & NA \\
\hline NimC4/Simu & NA & NA & NA & + \\
\hline Draper & + & + & NA & + \\
\hline Eater & + & + & NA & NA \\
\hline
\end{tabular}

\section{(NA=nincs adat)}

A Drosophila melanogasterben eddig azonosított fagocitózis receptorok jelentős mértékben redundáns funkciókkal rendelkeznek, például E. coli baktériumok fagocitálásában a PGRP-LC, TEPII, Peste, Croquemort, Dscam, Draper és Eater fehérje is szerepet játszik. A legtöbb adatunk a Schneider-2 sejteken végzett funkcióvesztéses vizsgálatokból származik, ezek azonban néhol ellentmondanak a funkciónyeréses vizsgálatokból származó adatoknak. A croquemort RNS inhibícióval történő csendesítése hatására például a Schneider-2 sejtek $S$. aureus fagocitáló képessége csökkent, ám E. coli fagocitáló képességük nem változott, míg a croquemort gént emberi sejtvonalban kifejeztetve, a sejtek $S$. aureus és $E$. coli fagocitáló képessége is emelkedett. Több fagocitózis receptor esetében csak arról rendelkezünk adatokkal, hogy a lehetséges ligandok egyik osztályának a bekebelezésében játszik szerepet, így például az Eater molekula kötődik Gram- 
negatív és Gram-pozitív baktériumokhoz is, de arról nincs adat, hogy a gombák vagy az apoptotikus sejtek fagocitózisában szerepet játszik -e (1. táblázat).

Az RNS inhibíciós vizsgálatok alapján arról is vannak ismereteink, hogy az egyes receptorok milyen arányban vesznek részt a fagocitózisban. Az eater, croquemort, Dscam, PGRP-LC és SR-CI gének egyidejü csendesítése körülbelül 90\%-kal csökkentette a Schneider-2 sejtek E. coli és $S$. aureus fagocitáló képességét (1. ábra), azonban az eater gén csendesítése önmagában 50\%-kal csökkentette a sejtek fagocitáló képességét, a többi receptor szerepe ehhez képest lényegesen szerényebb. A croquemort, Dscam, PGRP-LC és SR-CI gének együttes lecsendesítése kisebb mértékben csökkenti a sejtek fagocitáló képességét, mint önmagában az eater gén csendesítése (Ulvila és mtsai., 2011).

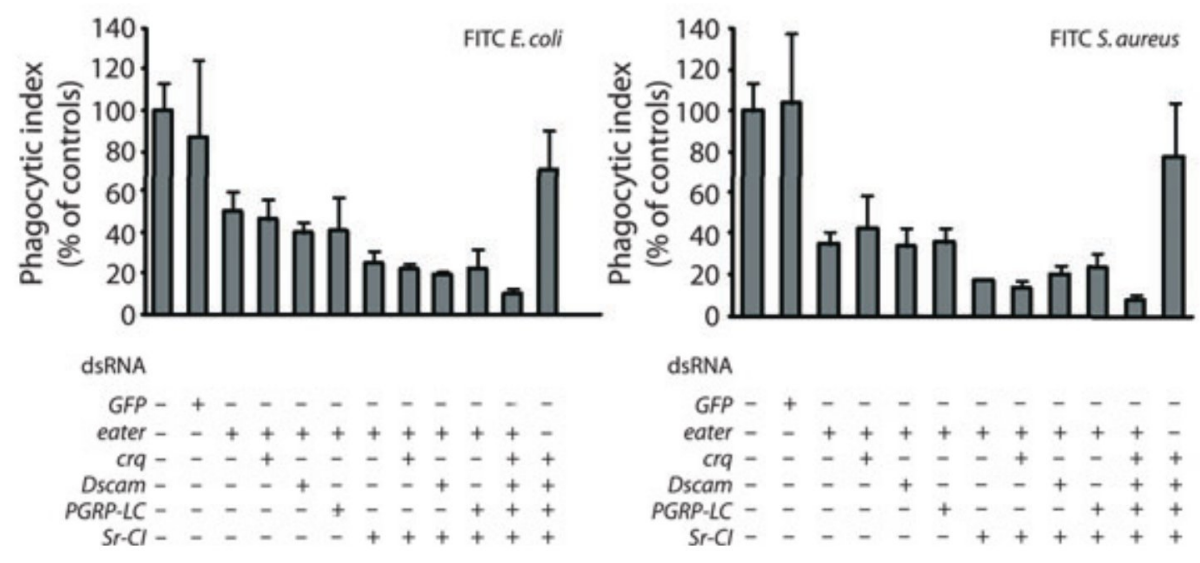

1. ábra: Az eddig ismert fagocitózis receptorok szerepe Schneider-2 sejtek fagocitózisában

Az eddig leirt fagocitózis receptoroknak a bekebelezés folyamatában betöltött szerepét Schneider2 sejtvonalban végzett RNS inhibicióval hasonlitották össze. Az eater gén RNS inhibiciós csendesitése csökkenti legnagyobb mértékben az E. coli és a S. aureus baktériumok fagocitózisát, míg a croquemort, Dscam, PGRP-LC, SR-CI szerepe lényegesen kisebb e két baktérium bekebelezésében (Ulvila és mtsai., 2011).

\subsection{A NimC1 fehérje doménszerkezete és a nimród géncsalád}

A D. melanogaster hemocitái molekuláris markerek segítségével is azonosíthatóak (Kurucz és mtsai., 2007a). Az első, kizárólag a plazmatocitákra jellemző transzmembrán fehérje az általunk azonosított NimC1 (Kurucz és mtsai., 2007b). A NimC1 fehérje a transzmembrán fehérjékre jellemző doménszerkezetet mutat: Rendelkezik szignál peptiddel, extracelluláris, transzmembrán és intracelluláris régiókkal. Az extracelluláris régió számos prediktált O- és N-glikozilációs hellyel rendelkezik, míg az intracelluláris régió számos prediktált szerin, treonin és tirozin foszforilációs 
helyet tartalmaz (Blom és mtsai., 1999). Az extracelluláris régió a számítógépes predikció szerint tíz EGF domént tartalmaz, ám a NimC1 fehérjében található EGF domének a többi ismert EGF doménhez képest konzerváltabbak, szigorúbb konszenzusszekvenciával írhatóak le, így ezt a domént elneveztük NIM doméneknek. A NIM domén, (konszenzusszekvenciája: CxPxCxxxCxNGxCxxPxxCxCxxGY) és az EMI domén feltételezhetően két EGF domén átrendeződésével jött létre (Callebaut és mtsai., 2003; Somogyi és mtsai., 2008).

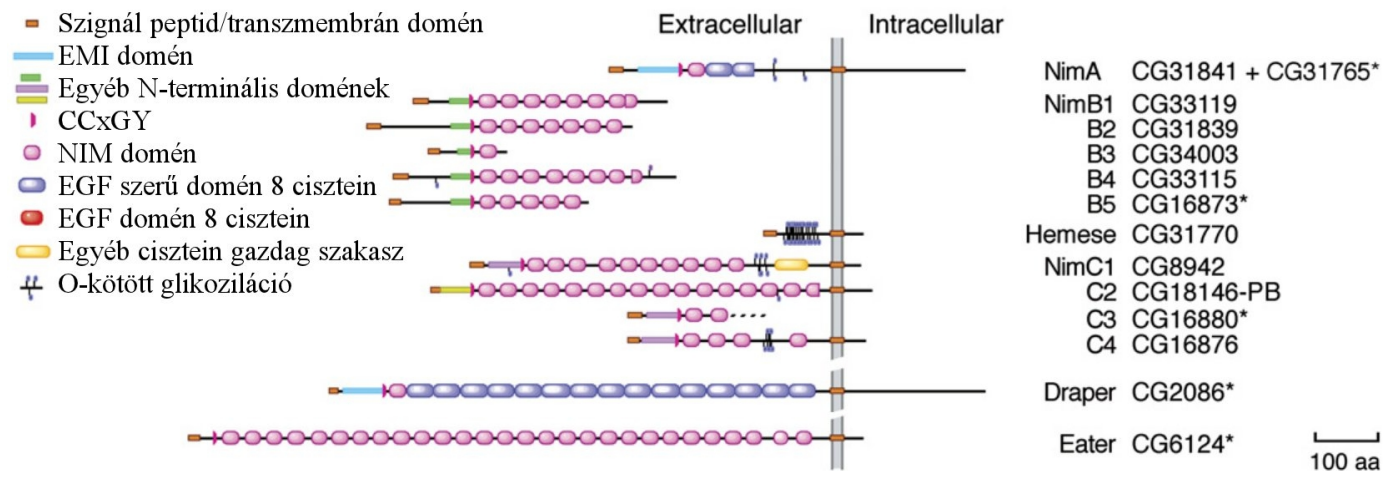

2. ábra: A Drosophila melanogaster genomban kódolt NIM domént tartalmazó fehérjék

A Nimród fehérjék mindegyike rendelkezik szignál peptiddel, legalább egy NIM doménnel és egy CCXGY szekvenciával. A NimC fehérjék 2-16 NIM doménjük mellett transzmembrán doménnel rendelkeznek, kivéve a NimC3 fehérjét, amely nem rendelkezik transzmembrán doménnel, ám a génklaszteren belüli elfoglalt helye és szekvenciájának a a NimC fehérjékhez mutatott hasonlósága alapján a NimC fehérjék közé soroljuk. A NimB fehérjék 1-9 NIM doménnel rendelkeznek, ám nem tartalmaznak transzmembrán domént, így valószinüsithetöen szekretáltak. A NimA típusú Draper és a NimC típusú Eater fehérjéket kódoló gének a klasztertöl távol találhatóak a genomban.

A Drosophila melanogaster genomja számos NIM domént tartalmazó receptormolekulát kódol (2. ábra). A nimC1 gén közvetlen genomi környezetében kilenc NIM domént hordozó fehérjét kódoló gén található, amelyek a munkacsoportunkban azonosított Nimród fehérje- és géncsaládot alkotják, melyek mindegyike tartalmaz egy rövid CCxGY motívumot, valamint egy szignál peptidet. A nimród géncsalád tagjai az általuk kódolt fehérjék doménszerkezeti jellegzetességei alapján három csoportra oszthatóak. A NimA fehérje a Draper fehérjéhez hasonlóan egyetlen NIM doménnel és több EGF doménnel rendelkezik, valamint transzmembrán domént is hordozó sejtfelszíni molekula. Az öt NimB típusú fehérje egy-nyolc NIM doménnel rendelkezik és nem tartalmaz transzmembrán domént, így ezek valószínüleg szekretált fehérjék. A négy NimC típusú fehérje kettő-tizenhat NIM domént tartalmaz, valamint közülük három transzmembrán doménnel is rendelkezik. A NimC3 fehérje nem rendelkezik transzmembrán doménnel, ám a génjének a klaszteren belül elfoglalt helye és a többi NimC fehérjéhez való hasonlósága alapján a NimC típusba soroltuk (2. ábra). 
A nimród géncsalád genomi környezetén kívül található további két NIM domént tartalmazó fehérjét kódoló gén, a draper és az eater. A Draper fehérje egyetlen NIM domént tartalmaz és tizenöt EGF domént, bár megtalálható benne a nimród géncsaládra jellemző szignál peptid, a CCxGY motívum és transzmembrán domén, így doménszerkezete alapján a NimA típusú fehérjék közé tartozik (2. ábra), de mivel a fehérjét kódoló gén nem a nimród génklaszter területén található a genomban, így nem soroljuk a Nimród fehérje- és géncsaládba.

Az Eater fehérje huszonhat NIM domént hordoz, emellett rendelkezik szignál peptiddel, CCxGY motívummal és transzmembrán doménnel, doménszerkezete a NimC fehérjékéhez hasonló (2. ábra), ám mivel az eater gén nem a nimród génklaszterben található, nem soroljuk a Nimród fehérje- és géncsaládba.

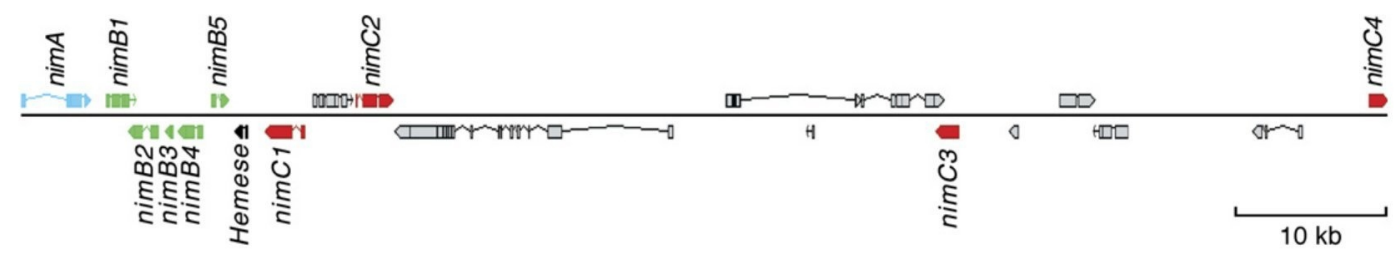

\section{3. ábra: A nimród géncsalád szerkezete}

A nimA (kék), nimB1-5 (zöld), nimC1-4 (piros) gének a Drosophila melanogaster második kromoszómáján helyezkednek el egy 88 kilobázispárnyi genomi szakaszon belül. Ugyanerre a genomi szakaszra térképezödik a korábban általunk azonositott Hemese transzmembrán fehérjét kódoló gén is (Kurucz és mtsai., 2003). Az egyes nimC gének között egyéb, NIM domént nem hordozó fehérjéket kódoló gének is megtalálhatóak (szürke).

A Nimród fehérje- és géncsalád minden jel szerint önálló egységet alkot: A Nimród fehérjéket kódoló gének egymás közvetlen genomi környezetében találhatóak a $D$. melanogaster második kromoszómáján (3. ábra). Ez a genomi régió tizenkét Drosophila faj genomjának összehasonlító elemzése alapján az egyik legnagyobb szintenikus régiót alkotja (Bhuktar és mtsai., 2008), egyes elemzések alapján a nimród gének kifejeződése azonos mértékben változik különböző stresszhatásokra és immunindukció hatására, ez azt valószínüsíti, hogy közös szabályozás alatt állhatnak. Számos ízeltlábú genomban megtalálható a nimród génklaszter (Somogyi és mtsai., 2010). Az Anopheles gambiae maláriaszúnyogban, Tribolium castaneum lisztbogárban és az Apis mellifera mézelö méhben is egymás közvetlen genomi környezetében találhatóak a NimA, NimB és NimC gének (4. ábra). 


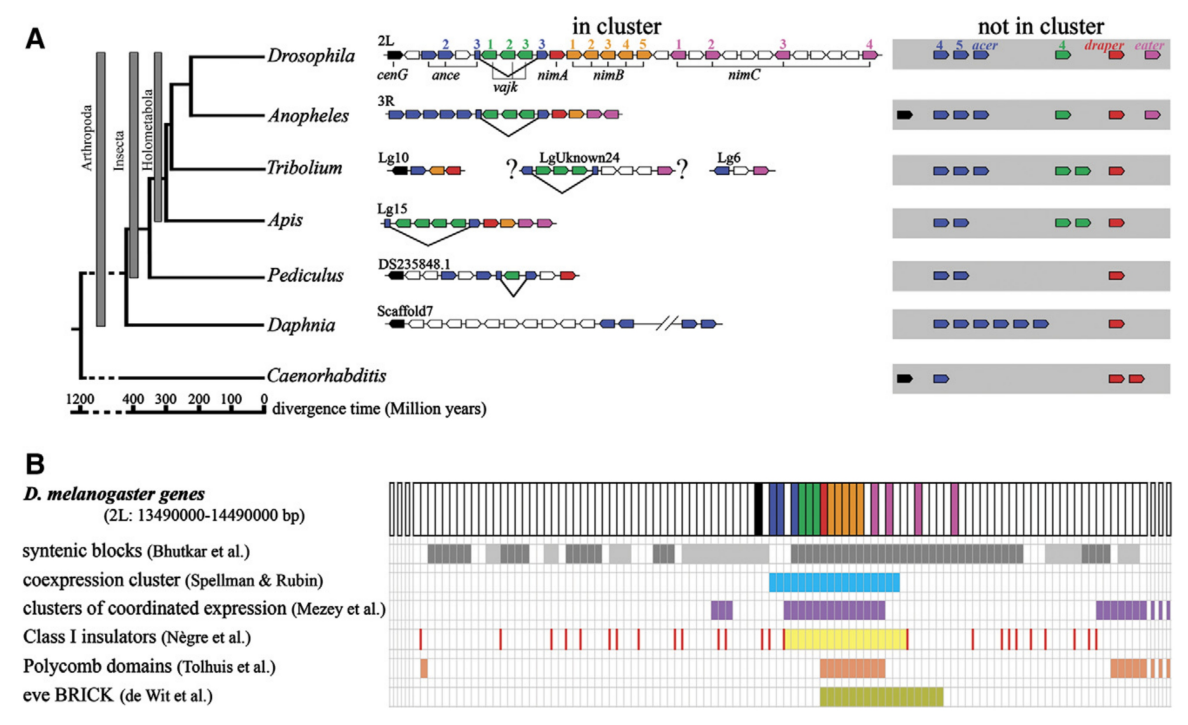

\section{4. ábra: A nimród géncsalád erösen konzervált a teljes átalakulással fejlödö rovarokban}

Bár a teljes átalakulással fejlödö rovarok genomjában a génklaszter tagjainak a száma különbözö, a nimród génklaszter felépitése azonos: ance gének, az egyik ance gén intronjában található vajk gének, majd a nimA, a nimB gének és végül a nimC gének alkotják. Bár a gének száma az ecetmuslicában (D. melanogaster), maláriaszúnyogban (A. gambiae) és a mézelö méhben (A. mellifera) különbözö, ezekben a fajokban az óriási evolúciós távolság ellenére a gének sorrendje erösen konzervált, ami arra utal, hogy valószínüleg szelekciós nyomás hat a klaszter felbomlása ellen (A). A nimród géncsalád szintenikus régiót alkot és arra vonatkozóan is rendelkezésünkre állnak adatok, hogy az itt található gének közös szabályozás alatt állnak (B) (Somogyi és mtsai., 2010).

A nimród génklaszter szerveződése az ecetmuslicáéhoz hasonló az Apis mellifera mézelő méhben és az Anopheles gambiae maláriaszúnyogban is. A mézelő méh és a maláriaszúnyog genomjában egyaránt egyetlen NimA, egyetlen NimB és két NimC típusú fehérjét kódoló gén alkotja a nimród klasztert. A klaszteren kívül található egy-egy Draper homológot kódoló gén, ám a nimród klaszteren kívül nem található NimC típusú fehérjét kódoló gén (5. ábra). 


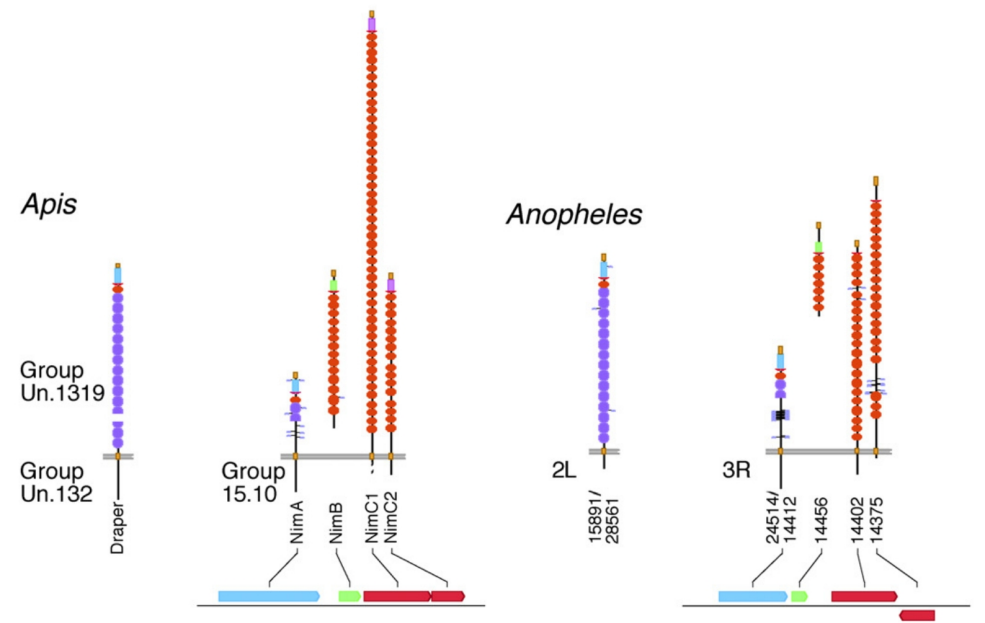

\section{5. ábra: A nimród génklaszter a mézelö méh és a maláriaszúnyog genomjában}

Az Apis mellifera mézelö méh és a Anopheles gambiae maláriaszúnyog nimród génklasztere egyaránt négy nimród gént tartalmaz, egyetlen NimA, egyetlen NimB valamint két NimC típusú fehérjét kódoló gén található egymás közvetlen genomi környezetében. Mindkét genomban egyetlen Draperhez hasonló molekulát kódoló gén található a klaszteren kívül.

A NimB és NimC típusú fehérjéknek nem ismertek gerinces homológjai, ezek a fehérjék valószínüleg a teljes átalakulással fejlödő rovarok közös ősében jelenhettek meg, ám több más gerinces fehérje is a NimA és a Draper fehérjékkel egyező doménszerkezetet mutat. Ilyen az egér Jedi/PEAR1 fehérje és ortológja, az emberi MEGF10 fehérje, melyek N-terminális végükön szignál peptiddel rendelkeznek, egy-egy EMI domént és egy-egy NIM domént tartalmaznak, valamint CCXGY motívummal rendelkeznek. Az egyetlen NIM doménjük mellett számos EGF domént is hordoznak. Ezek a fehérjék valószínüleg a fagocitózis folyamatában játszanak szerepet, hiszen az egér Jedi/PEAR-1 vagy az emberi MEGF10 fehérjét HEK 293 sejtvonalban kifejeztetve a sejtek a kontrollhoz képest több apoptotikus idegsejttörmeléket kötnek meg a felszínükön, a jedi gén RNS inhibícióval történő csendesítése csökkenti a fagocitózis hatékonyságát (Wu és mtsai., 2009), valamint az emberi MEGF10 fehérje HeLa sejtekben kifejeztetve megnöveli a sejtek apoptotikus sejt fagocitáló képességét. Az emberi MEGF10 fehérje a GULP fehérjével alkot heterodimert, ahogy a MEGF10 C. elaegans ortológja, a CED-1 a GULP ortológjával, a CED-6-tal képez komplexet. Az emberi MEGF10 fehérje képes menteni a C. elaegans CED-1 fehérje hiányát, így egyértelmüen annak ortológjaként jellemezhető (Hamon és mtsai., 2006). 


\section{Célkitüzések}

A P1 antigén tömegspektrometriai elemzésének eredményeként kapott peptid egy transzmembrán fehérjét kódoló gént azonosított, amelyet nimCl génnek neveztünk el. Funkcióvesztéses és funkciónyeréses vizsgálatokkal kívánjuk bizonyítani, hogy az ellenanyag által felismert P1 antigént valóban a nimC1 gén kódolja.

$\mathrm{Az}$ in silico módszerrel azonosított nimród génklasztert alkotó nimród gének szerepének vizsgálata során meg kívánjuk határozni a nimród gének transzkripciós aktivitását. Ezzel kizárhatjuk a további vizsgálatokból azokat az esetlegesen a génklaszterben található pszeudogéneket, amelyekről nem képződik messenger RNS.

Azonosítani kívánjuk a NimC1 fehérje funkcióját. Mivel a NimC1 doménszerkezete hasonló az Eater mintázatfelismerő receptoréhoz, ezért elképzelhető, hogy a NimC1 molekula mintázatfelismerő receptorként müködve a mikróbák felismerésében játszik szerepet. Baktériumkötési kísérletekkel kívánjuk megmérni, hogy a NimC1 képes-e a különböző baktérium törzsek sejtjeivel komplexet képezni.

A nimród génklasztert alkotó további nimród gének immunválaszban betöltött szerepének meghatározásához eukarióta rendszerben rekombináns Nimród fehérjéket állítunk elő és vizsgáljuk azok baktériumkötési kapacitását.

15. oldal 


\section{Anyagok és módszerek}

\subsection{Anyagok}

4X Mintapuffer: 2,6 ml desztillált vízhez adtunk $1 \mathrm{ml}$ 0,5 M TRIS-t ( $\mathrm{pH}=6,8) ; 2 \mathrm{ml}$ glicerint (87\%), 1,6 ml $10 \%$ SDS-t és 1 szemcse brómfenolkéket, majd az oldatot 8 ml-re egészítettük ki desztillált vízzel.

Alkalikus lízis I. oldat: 50 mM glükóz; 25 mM Tris-Cl (pH=8.0); 10 mM EDTA (pH=8.0).

Alkalikus lízis II. oldat: Minden esetben frissen készítettük. 0,2 M NaOH; 1\% (w/v) SDS.

Alkalikus lízis III. oldat: $60 \mathrm{ml} 5$ M Kálium-acetátot és 11,89 ml 96\%-os ecetsavat adtunk 28,14 ml desztillált vízhez.

Ampicillin felhasználása: $100 \mathrm{mg} / \mathrm{ml}$-es törzsoldatot készítettünk a por alakú ampicillinböl, a, 70\%-os etanolban oldva. Ebböl a törzsoldatból $1 \mu 1$-t használtunk a táptalaj minden egyes milliliteréhez.

DEPC kezelt $\mathbf{H}_{2} \mathrm{O}:$ 0,05\% dietil-pirokarbonáttal egy éjszakán át kezelt, majd autoklávozott desztillált víz.

Futtatópuffer: 0,25 M TRIS, 1,94 M Glicin, 1\% SDS.

Gentamicin felhasználása: $10 \mathrm{mg} / \mathrm{ml}$ törzsoldatot készítettünk a por alakú gentamicinből, desztillált vízben oldva, majd szüréssel csíramentesítettük. A törzsoldatból $140 \mu l$-t használtunk 200 ml LB táptalajhoz.

Hemocita lízispuffer: $50 \mathrm{mM}$ TRIS ( $\mathrm{pH}=7.0$ ), $150 \mathrm{mM} \mathrm{NaCl}, 0,5 \%$ Nonidet P-40, $0,2 \%$ nátrium deoxikolát, $1 \mathrm{mM}$ PMSF és Complete protease inhibitor cocktail (Roche).

IPTG felhasználása: $100 \mathrm{mM-os} \mathrm{törzsoldatot} \mathrm{készítettünk} \mathrm{a} \mathrm{por} \mathrm{alakú} \mathrm{IPTG-ből} \mathrm{(Fermentas).}$ Egy agarlemezre $40 \mu 1100$ mM-os IPTG oldatot szélesztettünk.

Kanamicin felhasználása: $75 \mathrm{mg} / \mathrm{ml}$ törzsoldatot készítettünk a por alakú kanamicinböl, desztillált vízben oldva, majd szüréssel csíramentesítettük. Ebböl a törzsoldatból $33 \mu 1-\mathrm{t}$ használtunk $50 \mathrm{ml} \mathrm{LB}$ táptalajhoz.

LB táptalaj: $10 \mathrm{~g}$ triptont, $5 \mathrm{~g}$ élesztökivonatot, $5 \mathrm{~g} \mathrm{NaCl-t}$ adtunk 1 liter desztillált vízhez, majd az oldat pH-ját 7,0-7,5-re állítottuk be $\mathrm{NaOH}$-val, és autoklávoztuk. Szilárd LB táptalajhoz literenként 20 g Bacto-agart adtunk.

Lipopoliszaccharid (LPS): A K12 E. coli törzsből származó lipopoliszaccharid (Invivogen \#tlrl-peklps). 
Loading puffer: $690 \mu$ 87\%-os glicerint és $120 \mu \mathrm{l}$ 0,5 M EDTA-t adtunk $189 \mu$ desztillált vízhez. Az oldathoz brómfenolkék törzsoldatot adtunk, amíg halvány kékeslila színü nem lett. Felhasználáskor $5 \mu$ puffert adtunk $25 \mu$ DNS oldathoz.

Peptidoglikán (PG): A K12 E. coli törzsböl származó peptidoglikán (Invivogen, \#tlrl-kipgn).

Sf9 lízispuffer: $150 \mathrm{mM} \mathrm{NaCl}, 40 \mathrm{mM}$ TRIS $\mathrm{pH}=7,5,10 \%$ glicerin, 0,1\% NP40, $5 \mathrm{mM}$ EDTA, 1 mM PMSF és PIC.

SOB táptalaj: $10 \mathrm{~g}$ triptont, 2,5 g élesztőkivonatot, 0,2922 g NaCl-t, 0,0932 g KCl-t, $500 \mathrm{ml}-$ re kiegészítettük desztillált vízzel, majd autoklávoztuk. Felhasználás előtt hozzáadtunk: 5 ml 1M-os sterilre szürt glükóz oldatot, $5 \mathrm{ml} 1 \mathrm{M}$-os sterilre szürt $\mathrm{MgCl}_{2}$ oldatot, $5 \mathrm{ml} 1 \mathrm{M}$-os sterilre szürt $\mathrm{MgSO}_{4}$ oldatot.

TB puffer: $10 \mathrm{mM}$ HEPES-t, $15 \mathrm{mM} \mathrm{CaCl}_{2}$-t, $250 \mathrm{mM} \mathrm{KCl-t} \mathrm{egészítettünk} \mathrm{ki} 500$ ml-re. A kész oldatot $\mathrm{pH}=6.7$-re állítottuk be $\mathrm{KOH}$-dal, majd autoklávoztuk. Felhasználás előtt minden 500 ml-éhez $11 \mathrm{ml}$ 2,5M-os sterilre szürt $\mathrm{MnCl}_{2}$ oldatot adtunk.

Tetraciklin felhasználása: $10 \mathrm{mg} / \mathrm{ml}$-es törzsoldatot készítettünk a por alakú tetraciklinböl, desztillált vízben oldva, majd szüréssel csíramentesítettük. Ebböl a törzsoldatból $150 \mu$ l-t használtunk $100 \mathrm{ml}$ LB táptalajhoz.

TNM-FH insect medium: (Sigma T1032) Felhasználás előtt minden literét kiegészítettük 0,1 g Streptomicinnel, 0,065 g Penicillinnel valamint 10\% marha szérummal és $5 \mathrm{mM}$ glutaminnal.

"Ultra pure" lipopoliszaccharid (LPS): A K12 E. coli törzsből származó lipopoliszaccharid (Invivogen, \# tlrl-peklps).

X-Gal felhasználása: $25 \mathrm{mg} / \mathrm{ml}$ koncentrációjú X-Gal (Fermentas) oldatot készítettünk dimetil formamidban feloldva a por alakú X-Galt. Ebböl az oldatból $40 \mu$ l-t szélesztettünk egy 10 cm átmérőjü agarlemezre.

\section{Drosophila melanogaster törzsek}

Oregon-R: Vad típusú törzs.

l(3)mbn-1 (lethal (3) malignant blood neoplasm): EMS indukált recesszív letális mutáció, a homozigóták a 3. lárvális stádiumban vagy a bábozódáskor pusztulnak el. Az l(3)mbn-1 gén egy tumor szuppresszor fehérjét kódol, a homozigóta mutáns egyedeknek a vad típusúnál százötvenszer több vérsejtje van (Gateff, 1977). A lárva hemocitái melanizált tumorokat fejlesztenek. A kísérletekhez 3. stádiumú lárvákat használtunk. A törzset TM6 balanszer kromoszómával tartottuk 
fenn, a homozigóták az ezen található Tubby $(\mathrm{Tb})$ marker alapján különböztethetök meg a heterozigóta lárváktól (Konrad és mtsai., 1994).

Hml-Gal4.4, UAS-2XEGFP; l(3)mbn-1: Hemocita túltermelő törzs, amelyben ellenanyagainkkal nem mutatható ki a NimC1 fehérje. A törzs egy, a transzgénektől független háttérmutációt tartalmaz a transzgéneket is hordozó második kromoszómáján. A spontán létrejött, vélhetőleg egy mozgékony genetikai elem helyváltoztatásakor keletkezett deléció a nimC1 gén második exonjának egy szakaszát érinti és leolvasási keret eltolódást okoz. A mutáns génről egy, a vad típusúnál rövidebb RNS molekula íródik át. A második kromoszómán hordozott hemolectin meghajtóelem a hemocitákban fejezi ki a GFP fehérjét, így azok zöld fluoreszcenciájuk alapján azonosíthatóak áramlási citometriás mérésekben (Goto és mtsai., 2003).

\section{Felhasznált sejtvonalak}

Schneider-2: A sejtvonalat Oregon-R, vad típusú Drosophila melanogaster törzsből származó embriók szöveteiből alapították. Sejtjei szilárd felülethez tapadnak és egyetlen sejt vastagságú réteget hoznak létre, ám könnyedén lemoshatóak, tripszinkezelés nélkül is. A sejtvonal sejtjeit embrionális makrofág jellegűként írták le, a sejtek nagy mennyiségben fagocitálnak mikróbákat, ezért a fagocitózis vizsgálatában elterjedt modellrendszer a Schneider 2 sejteken végzett in vitro fagocitózis vizsgálata. A sejtvonal lényeges tulajdonsága, hogy ellenanyagainkkal nem mutatható ki a NimC1 fehérje kifejeződése a sejtek felszínén.

Sf9: A sejtvonal Spodoptera frugiperda molylepke petefészkéből származik. A sejtek müanyag Petri-csészében szilárd felülethez tapadnak, ám tripszinkezelés nélkül is lemoshatóak, de rázatott kultúrában szuszpenzióként is fenntarthatóak. Az Sf9 sejtvonal érzékeny az Autographa californica multiple nuclear polyhedrosis vírus fertőzésére, ezért alkalmas a baculovírus alapú fehérjetermelésre.

\section{Baktériumtörzsek}

OmniMAX2 T1 törzs: Invitrogen C8540-03

$\mathrm{F}^{\prime} \quad\left\{\right.$ proAB $\left.+\quad l a c \mathrm{I}^{\mathrm{q}} \quad l a c \mathrm{Z} \Delta \mathrm{M} 15 \quad \operatorname{Tn} 10(\mathrm{TetR}) \quad \Delta(c c d \mathrm{AB})\right\} \quad m c r \mathrm{~A} \quad \Delta(m r r-h s d \mathrm{RMS}-m c r \mathrm{BC})$ $\varphi 80($ lacZ) $\Delta \mathrm{M} 15 \Delta$ (lacZYA-argF) U169 endA1 recA1 supE44 thi-1 gyrA96 relA1 tonA panD

DH10Bac: Invitrogen 10359-016

F- mer A $\Delta($ mrr -hsd RMS-mcr BC) $\Phi$ 80lac Z4 M15 $\triangle$ lacX74 rec Al end A1 ara D139 $\Delta$ (ara, leu )7697 gal U gal K $\lambda$-rps L nup G/bMON14272/pMON7124 
WaaC E. coli törzs: CGSC\#11805; JW3596-1 (Baba és mtsai., 2006)

LacY E. coli törzs: CGSC\#11893; JW0334-1 (Baba és mtsai., 2006)

Escherichia coli: SzMC 0582

Serratia marcescens: SzMC 0567

Xanthomonas campestris: SzMC 6181

Staphylococcus epidermidis: SzMC 14531

Bacillus subtilis: SzMC 0209

Bacillus cereus var. mycoides: SZMC 0042

Micrococcus luteus: SzMC 0264

\subsection{Módszerek}

Plazmid DNS izolálása alkalikus lízissel: Egy egyedi baktériumtelepet oltottunk le $2 \mathrm{ml}$ antibiotikummal kiegészített LB táptalajba. A baktériumokat $37{ }^{\circ} \mathrm{C}$-on rázatva egy éjszakán át növesztettük. 1,5 ml sejtszuszpenziót centrifugáltunk (13.000 rpm, 1 perc, $\left.4{ }^{\circ} \mathrm{C}\right)$, majd eltávolítottuk a felülúszót. A pellethez $100 \mu \mathrm{l}$ jéghideg I. oldatot adtunk, majd felszuszpendálásig vortexeltük. Hozzáadtunk $200 \mu \mathrm{l}$ frissen készített II. oldatot, majd óvatosan összekevertük. Hozzáadtunk $150 \mu 1$ jéghideg III. oldatot, majd óvatosan összekevertük. Öt percen át szobahőmérsékleten inkubáltuk, majd centrifugáltuk $\left(13.000 \mathrm{rpm}, 1\right.$ perc, $\left.4{ }^{\circ} \mathrm{C}\right)$. A felülúszót tiszta Eppendorf-csőbe helyeztük, majd $1 \mathrm{ml}$ etanolt (96\%) adtunk hozzá. Vortexeltük és negyven percen át $-20^{\circ} \mathrm{C}$-on inkubáltuk, majd centrifugáltuk $\left(13.000 \mathrm{rpm}, 20\right.$ perc, $\left.4{ }^{\circ} \mathrm{C}\right)$. Eltávolítottuk a felülúszót, majd a DNS pelletet $200 \mu \mathrm{l}$ etanollal mostuk $(70 \%)$, centrifugáltuk $\left(13.000 \mathrm{rpm}, 5\right.$ perc, $\left.4{ }^{\circ} \mathrm{C}\right)$, majd eltávolítottuk a felülúszót. Az üledéket szobahőmérsékleten szárítottuk. A DNS pelletet 30-70 $\mu 1$ TE pufferben oldottuk fel. 1 $\mu 10 \mathrm{mg} / \mathrm{ml}$ RNáz A oldatot adtunk hozzá.

DNS emésztése restrikciós endonukleáz enzimmel: $2 \mu$ alkalikus lízissel izolált plazmid DNS oldathoz hozzámértünk 2,5 $\mu \mathrm{l}$, az emésztésre használt enzimnek megfelelő $10 \mathrm{X}$ puffert (Fermentas), 20,3 $\mu$ l desztillált vizet, valamint $0,2 \mu$ l restrikciós endonukleázt (10 U/ $\mu 1$ Fermentas). Az oldatot egy órán át $37^{\circ} \mathrm{C}$-on inkubáltuk, majd agaróz gélelektroforézissel tettük láthatóvá az emésztés termékét.

DNS preparatív emésztése restrikciós endonukleáz enzimmel: $30 \mu \mathrm{l}$ alkalikus lízissel izolált plazmid DNS oldathoz hozzámértünk $10 \mu 1$ 10X puffert (Fermentas), $56 \mu$ desztillált vizet, valamint $4 \mu \mathrm{l}$ restrikciós endonukleázt $\left(10 \mathrm{U} / \mu \mathrm{l}\right.$ Fermentas). Az oldatot 2,5 órán át $37{ }^{\circ} \mathrm{C}$-on inkubáltuk. 
DNS ligálás: A ligáz reakciót $20 \mu$ végtérfogatban végeztük, a plazmid és az inszert DNS mennyiségét minden egyes reakció során egyedileg határoztuk meg, az oldatok DNS tartalma alapján, amelyet agaróz gélelektroforézissel határoztunk meg. Példaként $4 \mu$ plazmid DNS oldatot és $3 \mu \mathrm{l}$ inszert DNS oldatot használó reakciót írunk le: $4 \mu \mathrm{l}$ plazmid DNS oldat; $3 \mu \mathrm{l}$ inszert DNS oldat; $2 \mu$ ligáz puffer (10X Fermentas); $1 \mu \mathrm{l}$ T4 DNS ligáz enzim (1 U/ $\mu 1$, Fermentas); $10 \mu 1$ desztillált víz. A reakcióelegyet két órán keresztül $18{ }^{\circ} \mathrm{C}$-on inkubáltuk, majd egy aliquotnyi (100 $\mu 1)$ kompetens sejtet transzformáltunk vele.

Ragadós végekkel rendelkező inszertek ligálásakor egy kontrollreakciót is végeztünk, amelyben az inszertet kivéve minden szükséges összetevő megtalálható volt. Csak azoknak a ligátumoknak a telepeiböl dolgoztunk tovább, amelyek az inszert nélküli kontrollreakcióval transzformált kompetens sejteknél legalább kétszer több telepet eredményeztek.

Plazmid DNS izolálása oldatból: A plazmid DNS oldatból EZ-10 Spin Column PCR Purification Kit-tel (Bio Basic inc. BS353) izoláltuk a plazmid DNS-t, követve a gyártó által adott receptet. Az oszlopról $30 \mu \mathrm{l}$ Eluciós Pufferrel (10 mM TRIS-HCl pH=8,5) eluáltuk a plazmid DNSt.

Plazmid DNS izolálása gélből: A visszaizolálni tervezett DNS-t SybrSafe festékkel kiegészített agaróz gélen (1:10000 hígításban használtuk) választottuk el. Az agaróz gélben a SybrSafe festéket gerjesztő $470 \mathrm{~nm}$ hullámhosszú kék fénnyel tettük láthatóvá a DNS-t. Pengével kimetszettük a kívánt sávot, a kimetszett géldarabból EZ-10 Spin Column DNA Gel Extraction Kittel izoláltuk a DNS-t, követve a gyártó receptjét. Az oszlopról $30 \mu \mathrm{l}$ Eluciós Pufferrel (10 mM TRIS-HCl pH=8,5) eluáltuk a DNS-t.

Kompetens sejt transzformálása: Egy aliquotnyi $(100 \mu \mathrm{l})$ kompetens sejtet a $-80{ }^{\circ} \mathrm{C}$ hőmérsékletü hűtőből kiemelve azonnal jégbe helyeztünk, ami húsz perc alatt lassan felolvadt. Megfelelő mennyiségü plazmid DNS-t adtunk hozzá, alkalikus lízissel izolált cirkuláris plazmid DNS-ből 0,1-1 $\mu$ l-t, ligált plazmid DNS-ből a teljes $20 \mu$ l-nyi ligátumot, majd óvatosan felkevertük. Harminc percen át jégen inkubáltuk, majd 45 másodpercre $42{ }^{\circ} \mathrm{C}$ vízfürdőbe helyeztük. Három percen át jégen inkubáltuk, majd $900 \mu \mathrm{l}$ steril folyékony LB táptalajt adtunk hozzá. $37{ }^{\circ} \mathrm{C}$-on inkubáltuk negyvenöt percen át, majd a sejtszuszpenzióból $100 \mu$ l-t agarlemezre szélesztettünk. A maradék $900 \mu$ l-t centrifugáltuk (13.000 rpm, 1 per, szobahőmérséklet), eltávolítottuk a felülúszót, majd $200 \mu \mathrm{LB}$ táptalajban fölvéve a baktériumüledéket, egy agarlemezre szélesztettük. A két agarlemezt egy éjszakán át $37^{\circ} \mathrm{C}$-on inkubáltuk. 
DH10Bac kompetens sejt transzformálása: Egy aliquotnyi (100 $\mu$ l) kompetens sejtet húsz perc alatt lassan jégen kiolvasztottunk. Minden egyes aliquothoz $30 \mu 1$ alkalikus lízissel izolált DNS oldatot adtunk, majd harminc percen át jégen inkubáltuk, 45 másodpercre $42{ }^{\circ} \mathrm{C}$ vízfürdőbe helyeztük és két percen át jégen inkubáltuk. Hozzáadtunk $900 \mu 1$ steril LB táptalajt, majd négy órán át $37^{\circ} \mathrm{C}$-on rázattuk. A baktérium szuszpenziót kanamicinnel, tetraciklinnel, gentamicinnel, IPTGvel, X-Gal-lal kiegészített LB agarlemezre szélesztettük és 48 órán át $37{ }^{\circ} \mathrm{C}$-on inkubáltuk.

Kompetens sejtek készítése: Egy egyedi baktériumtelepből indultunk ki, ezt $5 \mathrm{ml}$, a megfelelő antibiotikummal kiegészített LB táptalajba oltottuk le. A kultúrát egy éjszakán át rázatva inkubáltuk $37{ }^{\circ} \mathrm{C}$-on. Másnap a kultúrát kettéosztottuk és 250-250 ml SOB táptalajhoz adtuk, majd $18{ }^{\circ} \mathrm{C}$-on 150 rpm-mel rázatva inkubáltuk a kultúrákat, amíg el nem érték a 0,6-0,8-as optikai denzitást, 600 nanométer hullámhosszúságú fényben mérve. A sejtszuszpenziókat steril centrifugacsövekbe töltöttük, majd tíz percen át jégen inkubáltuk. A kultúrákat centrifugáltuk (5000 rpm, 10 perc, $4 \mathrm{C}^{\circ}$ ), eltávolítottuk a felülúszót, majd a baktériumpelleteket $80 \mathrm{ml}$ jéghideg TB pufferben szuszpendáltuk fel. A szuszpenziót tíz percen át jégen inkubáltuk, majd centrifugáltuk (4000 rpm, 10 perc $4{ }^{\circ} \mathrm{C}$ ). Eltávolítottuk a felülúszót, majd a sejtpelleteket $20 \mathrm{ml}$ jéghideg TB pufferben szuszpendáltuk el. Lassan, folyamatos keverés mellett hozzáadtunk 7\%-nyi végkoncentrációban DMSO-t. A sejtszuszpenziókat tíz percen át jégen inkubáltuk, majd minden Eppendorf-csőbe $100 \mu \mathrm{l}$-t mértünk ki belölük, amelyeket azonnal folyékony nitrogénbe ejtve fagyasztottunk, majd- $80{ }^{\circ} \mathrm{C}$-on tároltunk.

Élő hemociták áramlási citometriás elemzése: Egy 96 lyukú lemez egy lyukába harmadik stádiumú lárvákból izolált $2 \times 10^{5}$ hemocitát helyeztünk, $20 \mu$ líz százaléknyi marha szérummal kiegészített Schneider táptalajban. Az elsődleges ellenanyagból $50 \quad \mu l-t$ mértünk egy mintához majd 45 percen át inkubáltuk jégen. A sejteket háromszor mostuk jéghideg Schneider táptalajban, hozzáadtuk a másodlagos ellenanyagot, 1:100 hígításban FITC jelölt anti-egér immunglobulint (Sigma) vagy 1:1000 hígításban Alexa Fluor 633 jelölt anti-egér immunglobulint (Invitrogen), majd 45 percen át jégen inkubáltuk. A sejteket háromszor mostuk jéghideg Schneider táptalajban, majd a fluoreszcencia intenzitásukat egy FACSCalibur áramlási citométerrel mértük meg.

Indirekt immunfluoreszcencia: Harmadik stádiumú lárvákat véreztettünk ki PTU-val kiegészített Drosophila Ringer oldatba. A hemocitákat 45 percen át inkubáltuk szobahőn, nedveskamrában, hogy a sejtek kitapadjanak a tárgylemezhez. A kitapadt sejteket 2\%-os paraformaldehid oldatban fixáltuk 12 percen át, majd háromszor mostuk PBS-ben. A mintát 0,1\% BSA-t tartalmazó PBS-ben telítettük, 15 percen át. Az elsődleges ellenanyaggal egy éjszakán át 
inkubáltuk a mintát nedveskamrában, majd háromszor mostuk PBS-ben. Másodlagos ellenanyagként 45 percen át inkubáltuk 0,1\% BSA-PBS oldatban 1:300 hígított fluoreszcensen jelölt anti-egér ellenanyagot, az oldatot kiegészítve 1:200 hígításban DAPI DNS festékkel. A tárgylemezeket háromszor mostuk PBS-ben, majd beágyazó médiummal fedtük.

In vivo fagocitózis: Egy 96 lyukú lemez egy lyukába harmadik stádiumú lárvákból hemocitákat izoláltunk tízszázaléknyi marha szérummal és PTU-val kiegészített Schneider táptalajba. Tíz percen át szobahőn inkubáltuk a sejteket, majd $2 \times 10^{6}$ hővel elölt, FITC-cel fluoreszcensen jelölt baktériumsejtet adtunk hozzá. Húszpercnyi szobahőn inkubálás után a be nem kebelezett baktériumok fluoreszcenciájának kioltására tripánkéket adtunk a sejtszuszpenzióhoz, 0,2\% végkoncentrációban, majd azonnal megmértük a sejtek fluoreszcencia intenzitását egy FACSCalibur áramlási citométerrel.

RNS inhibíciós konstrukt készítése: A nimCl gén RNS inhibíciós csendesítéséhez egy dsRNS konstruktot készítettünk (AB186054), amelyben a nimC1 gén 5' nem transzlálódó régiójának egy 403 bázispár hosszúságú szakaszát használtuk, amelyet mindkét orientációban egy pUAST vektorba klónoztuk, a wingless gén 1177 bázispár hosszúságú intronjával elválasztva. A konstruktot P-elem transzpozáz enzimet kódoló helper plazmid segítségével juttattuk a $\mathrm{w}^{1118}$ törzs genomjába. A kiválasztott szakasz, amelyből a kettősszálú RNS kialakul, nem tartalmaz tizenhat bázispárnál hosszabb egyezést egyetlen más $D$. melanogaster génnel sem.

A NimC1 fehérje kifejeztetése Schneider-2 sejtekben: Az LP05465 azonosítószámú nimC1 cDNS klónból indultunk ki, az EcoRI-XhoI emésztéssel kapott inszertet klónoztuk a pMT/V5-HISA vektorba. A vektor ellenőrzésekor azt tapasztaltuk, hogy a cDNS klón két bázispárnyi deléciót tartalmaz a genomi szekvenciához képest az 1564. bázispárnál, aminek hatására a cDNS-ről trunkált NimC1 fehérje íródik át. Hogy ezt a hibát kijavítsuk, a nimCl génben található BamHI hasítóhelytől downstream irányban 1,8 kilobázis méretű szakaszt amplifikáltunk polimeráz láncreakcióval genomi DNS templátról, majd ezt a fragmentet klónoztuk a pMT/V5-HIS vektorba. A Schneider-2 sejteket Effectene reagenssel (Quiagen) transzfektáltuk, majd a rekombináns NimC1 kifejeződését réz-szulfát hozzáadásával indukáltuk. A sejteket a réz-szulfát indukció után négy nappal használtuk fel a kísérleteinkhez.

RNS izolálás: A Gibco BRL TRIZOL reagensét használtuk RNS izolálásra, pontosan követve a gyártó cég által megadott használati utasítást. 5-10 x $10^{6}$ izolált hemocitához $1 \mathrm{ml}$ TRIZOL reagenst használtunk, majd többszöri pipettázással homogenizáltuk a sejteket. Harmadik stádiumú lárvából 22 egyedet használtunk $1 \mathrm{ml}$ TRIZOL reagenshez. Az egész lárvákat a TRIZOL reagensben 
homogenizáltuk, és egy külön tisztítási lépésben centrifugáltuk $\left(12.000 \mathrm{rpm}, 10\right.$ percig $\left.4{ }^{\circ} \mathrm{C}\right)$, majd a felülúszót használtuk. Öt perc szobahőmérsékleten történő inkubálás után $0,2 \mathrm{ml}$ kloroformot adtunk hozzá az eredeti TRIZOL reagens minden milliliteréhez. Rövid rázás, és 3 perces szobahőmérsékleten történő inkubálás után centrifugáltuk $\left(12.000 \mathrm{rpm}, 15\right.$ perc, $\left.4{ }^{\circ} \mathrm{C}\right)$. A vizes fázist Eppendorf-csőbe mérve, az eredeti TRIZOL minden mililiteréhez 0,5 ml izopropil alkoholt adtunk. Tíz perces szobahőmérsékleten történő inkubálás után centrifugáltuk (12.000 rpm, 10 perc, $4{ }^{\circ} \mathrm{C}$ ). A felülúszót eltávolítottuk az RNS csapadékról. A kapott csapadékot 75\%-os etil-alkohollal mostuk, majd centrifugáltuk (7500 rpm, 5 perc, 4 C) és levegőn szárítottuk, amíg gélállapotúvá nem vált. Az RNS-t DEPC-kezelt desztillált vízben oldottuk.

Reverz transzkripció: $5 \mu \mathrm{g}$ izolált teljes RNS-t tartalmazó oldatból indultunk ki. Az oldathoz $5 \mu \mathrm{l} \quad 0,1 \mathrm{mg} / \mathrm{ml}$ koncentrációjú random hexamer primer oldatot mértünk hozzá, majd $10 \mu 1$ végtérfogatra egészítettük ki DEPC-kezelt desztillált vízzel. A reakcióelegyet $70{ }^{\circ} \mathrm{C}$-on tíz percen át inkubáltuk, majd jégen hütöttük. Hozzámértünk $10 \mu \mathrm{l}$ X RT puffert (Fermentas), $4 \mu 10 \mathrm{mM}$ dNTP keveréket (Fermentas), 20 U RNáz inhibítort (Fermentas), 40 U M-MuLV reverz transzkriptáz enzimet (20 U/ $\mu 1$ Fermentas), majd $50 \mu$ l végtérfogatra egészítettük ki DEPC kezelt desztillált vízzel. A reakcióelegyet tíz percen át szobahőmérsékleten inkubáltuk, majd egy órán át $42{ }^{\circ} \mathrm{C}$-on, majd 5 percen át $70{ }^{\circ} \mathrm{C}$-on. A reakció termékét $12,5 \mu$ l-nyi aliquotokra osztottuk, majd -20 ${ }^{\circ} \mathrm{C}$-on tároltuk.

Polimeráz láncreakció (PCR): A polimeráz láncreakciókat a MJ Research által gyártott PTC-0200 DNA Engine-en végeztük, olajrétegzés nélkül, a csövek tetejét fütve. A láncreakció első lépéseként 3 percre $95^{\circ} \mathrm{C}$-ra melegítettük a reakcióelegyet. Maga a láncreakció 3 lépésböl állt: 95 ${ }^{\circ} \mathrm{C}$ on 30 másodpercig denaturáltuk a DNS-t (denaturálás), majd $58{ }^{\circ} \mathrm{C}$-on 45 másodpercig engedtük, hogy a primerek megtalálják a komplementer szekvenciákat (annealing), végül $72{ }^{\circ} \mathrm{C}$-on 1 perc 30 másodpercet hagytunk a lánchosszabbítási lépésre (elongáció). Az annealing fázis hőmérsékletét és az elongációs fázis időtartamát az egyes primerpárokhoz igazítottuk.

Egy $25 \mu$ l végtérfogatú reakcióhoz 14, $375 \mu$ d desztillált vizet, 2,5 $\mu 110 \mathrm{X}$ PCR puffert (Fermentas), $3 \mu \mathrm{l} 25 \mathrm{mM} \mathrm{MgCl}_{2} \mathrm{t}, 2,5 \mu \mathrm{l} 2 \mathrm{mM}$ dNTP keveréket (Fermentas), $1 \mu \mathrm{l}$ DNS templátot és 0,625 $\mu \mathrm{l}$ Taq polimeráz enzimet ( $1 \mathrm{U} / \mu \mathrm{l}$ Fermentas), valamint 0,5-0,5 $\mu \mathrm{l} 5 \mu \mathrm{mol} / 1$ koncentrációjú primert mértünk össze.

Hemocita lizátum készítése: A 3. stádiumú lárvák kutikuláját sztereomikroszkóp alatt megsértve, jéghideg $5 \%$ marha szérummal kiegészített Schneider-táptalajba csorgattuk 
hemolimfájukat. PTU-val előztük meg a vérsejtek melanizálódását, mivel a PTU a fenoloxidáz szubsztrátja, kompetitíven gátolja az enzim müködését és ez által a hemolimfa koagulálódását.

Egy mintát $5 \times 10^{6}$ hemocitából készítettünk, $400 \mu \mathrm{l}$ hemocita lízispuffer hozzáadásával. A sejteket háromszor szonikáltuk (1 perc), majd minden szonikálás után folyékony nitrogénben fagyasztottuk. A feltárás után a sejttörmeléket centrifugálással $\left(18.000\right.$ x g 10 perc $\left.4{ }^{\circ} \mathrm{C}\right)$ ülepítettük, kísérleteinkben a felülúszót használtuk fel.

FITC jelölt baktérium készítése: Tíz milliliternyi baktérium szuszpenzióból $\left(\mathrm{OD}_{600}=1,5\right)$ centrifugáltunk (4200 x g 20 perc $4{ }^{\circ} \mathrm{C}$ ), majd háromszor megmostuk PBS-ben és forrásban lévő vízben inaktiváltuk a sejteket (1 óra). A hővel elölt baktériumsejteket $10 \mathrm{ml} 0,25 \mathrm{M}$ karbonátbikarbonát pufferben ( $\mathrm{pH}$ 9.0) szuszpendáltuk fel, amelyben ez után cseppenként $100 \mu$ DMSO-ban oldott $0,5 \mathrm{mg}$ FITC-et oldottunk fel. A baktérium szuszpenziót egy éjszakán át forgattuk $\left(4^{\circ} \mathrm{C}\right)$, majd nyolcszor mostuk PBS-ben, hosszan vortexelve.

Baktériumkötési esszé: Egy Eppendorf-csőben centrifugáltuk $\left(11.200\right.$ x g, 4 perc, $\left.4{ }^{\circ} \mathrm{C}\right)$ le a FITC-E. colit (10 $\mu \mathrm{l})$ vagy a FITC-S. epidermidist ( $5 \mu \mathrm{l})$ és $400 \mu \mathrm{l}$ hemocita lizátummal egészítettük ki, majd egy éjszakán át $4{ }^{\circ} \mathrm{C}$-on forgattuk. A rekombináns fehérjéket termelő SF9 sejtek lizátumából $800 \mu \mathrm{l}$-t tettünk egy mintára. A baktériumsejteket centrifugálással ülepítettük (11200 x g 4 perc $4{ }^{\circ} \mathrm{C}$ ) és háromszor mostuk PBS-ben, minden mosási lépéskor harminc másodpercen át vortexelve. A baktériumpellethez $1 \mathrm{ml}$ elsődleges ellenanyagot adtunk, vagy P1a és P1b monoklonális egér ellenanyagok keverékét (Kurucz és mtsai., 2007a), vagy L1a és L1b egér monoklonális ellenanyagok keverékét (Kurucz és mtsai., 2007a, Honti és mtsai., 2009), vagy antiFLAG egér monoklonális ellenanyagot (1:1000 hígítottuk KRPMI-ben). Fél percnyi vortexelés után a mintát két órán át forgattuk $4{ }^{\circ} \mathrm{C}$-on, majd háromszor mostuk $5 \%$ szérummal kiegészített RPMI táptalajban. A baktériumpellethez másodlagos ellenanyagként $1 \mathrm{ml}$ Alexa Fluor 633 fluorokrómmal jelölt anti-egér IgG-t (Invitrogen) (1:600 hígítottuk KRPMI-ben) adtunk, majd 45 percen át forgattuk $4{ }^{\circ} \mathrm{C}$-on. Miután a baktériumpelletet háromszor mostuk 5\% szérummal kiegészített RPMI táptalajban és kétszer PBS-ben áramlási citometriával mértük a baktériumsejtek fluoreszcencia intenzitását. A baktériumsejteket az FL-1 csatornán mért FITC (zöld) fluoreszcenciájuk alapján különítettük el a törmeléktöl, és a kapuzott sejtpopuláció Alexa Fluor 633 (távoli vörös) fluoreszcencia intenzitását az FL-4 csatornán mértük egy FACSCalibur áramlási citométerrel.

Statisztikai elemzés: A vizsgált fehérjék baktériumkötését a távoli vörös tartományban mért fluoreszcencia intenzitások számtani közepével (MFI) jellemeztük. A NimC1 fehérjét felismerő ellenanyaggal festett minta MFI értékét elosztva a kontroll minta MFI értékével számítottuk ki a 
minta relatív MFI értékét (RMFI). Minden ábrán feltüntettük az RMFI értékek szórását is. Az áramlási citometriával mért MFI értékeken Student $t$-tesztet végeztünk, a baktériumkötést úgy határoztuk meg, mint ahol a minta MFI értékei szignifikánsan különböznek a kontroll MFI értékeitől, azaz a Student $t$-teszt eredményeként kapott p érték alacsonyabb 0,05-nél.

Kompetíciós baktériumkötési esszé: A kompetíciós baktériumkötési kísérletekben a hemocita lizátumhoz először a kompetitort adtuk hozzá, majd két órán át $4{ }^{\circ} \mathrm{C}$-on forgattuk, ez után végeztük el vele a baktériumkötési esszét.

Baktériumlizátum készítése: Egy minta $24 \mathrm{ml}$ E. coli szuszpenzióból $\left(\mathrm{OD}_{600}=1,3\right)$ ülepített sejtekből készült, amelyet $1 \mathrm{ml}$ lízisufferben szuszpendáltunk fel, harminc percen át jégen inkubáltunk, majd ötször szonikáltunk (1 perc) és nitrogénben fagyasztottunk, majd centrifugáltunk (18000 x g 10 perc $\left.4{ }^{\circ} \mathrm{C}\right)$.

Baktérium lizátum fehérjementesítése fenolkezeléssel: $250 \mu \mathrm{l}$. coli lizátumhoz $250 \mu \mathrm{l}$ fenolt adtunk, öt percen át vortexeltük, öt percen át szobahőmérsékleten, majd öt percen át jégen inkubáltuk. Lecentrifugáltuk (11200 x g 2 perc $\left.4{ }^{\circ} \mathrm{C}\right)$ és a $250 \mu$ l vizes fázist friss Eppendorf-csőbe helyeztük. A fenolt újabb $250 \mu \mathrm{l}$ friss lízispufferrel extraháltuk, majd a második vizes fázist összekevertük az elsővel. Az így kapott $500 \mu$ l vizes fázist $500 \mu 1$ fenollal kétszer extraháltuk. A kapott kétszer $500 \mu$ l vizes fázist összeöntöttük és $1 \mathrm{ml}$ fenollal kétszer extraháltuk. A kapott $2 \mathrm{ml}$ vizes fázishoz 9,1 $\mathrm{ml} \mathrm{96 \% -os} \mathrm{etanolt} \mathrm{és} 330 \mu$ nátrium-acetátot adtunk, majd két órán át -20 ${ }^{\circ} \mathrm{C}$-on inkubáltuk. Az oldatot centrifugáltuk (11200 x g 10 perc $\left.4{ }^{\circ} \mathrm{C}\right)$ és a felülúszót eltávolítottuk. Az üledéket $1 \mathrm{ml}-20{ }^{\circ} \mathrm{C}$-os $96 \%$ etanollal mostuk, majd $250 \mu$ lízispufferben oldottuk fel (Módosítva Hirschfeld és mtsai., 2000 alapján) .

Baktériumfehérjék emésztése Proteináz k enzimmel: $250 \mu \mathrm{l}$. coli lizátumhoz $1 \mathrm{mM}$ végkoncentrációban Proteináz $\mathrm{K}$ enzimet $\left(20 \mathrm{mg} / \mathrm{ml}\right.$, Fermentas) adtunk, majd három órán át $50{ }^{\circ} \mathrm{C}$ on inkubáltuk. A Proteináz $\mathrm{K}$ enzimet $4 \mathrm{mM}$ PMSF hozzáadásával gátoltuk, majd a mintát centrifugáltuk $\left(18000\right.$ x g 10 perc $\left.4{ }^{\circ} \mathrm{C}\right)$. A felülúszót használtuk a kompetíciós baktériumkötési esszében.

FLAG-taget kódoló plazmid készítése: A FLAG epitópot és az XbaI és NotI restrikciós endonukleázok hasítóhelyét kódoló génszegmentet két oligonukleotidként szintetizáltattuk meg mint 5'-CAATCTAGAGATTACAAAGACGACGACGACAAATAGTAAGCGGCCGCAAC-3' és a reverz komplement szekvenciája. A DNS szakasz 5' és 3' végét is kiegészítettük három-három véletlenszerüen kiválasztott bázissal, amelyek a restrikciós endonukleáz enzimek szubsztrátkötését segítik, ugyanis számos ilyen enzim alacsony hatékonysággal hasít 5' vagy 3' végi szubsztárot. 
Mindkét oligonukleotidból $1 \mathrm{nmol}$ végkoncentrációban adtunk $10 \mu \mathrm{l}$ desztillált vízhez és tíz percen át $95{ }^{\circ} \mathrm{C}$-on inkubáltuk, egy percen át $70^{\circ} \mathrm{C}$-on, 1 percen át $60^{\circ} \mathrm{C}$-on, egy percen át $50{ }^{\circ} \mathrm{C}$-on, két percen át $40{ }^{\circ} \mathrm{C}$-on inkubáltuk, hogy a két egyesszálú DNS szakasz kettősszálú DNS molekulákat hozzon létre. Az oldathoz 0,6 $\mu \mathrm{l}$ NotI (10 U/ $\mu \mathrm{l}$, Fermentas) és 0,6 $\mu \mathrm{l} \mathrm{XbaI} \mathrm{(10} \mathrm{U/ \mu l,} \mathrm{Fermentas)}$ enzimet, valamint $2 \mu \mathrm{l}$ BamHI puffert (10X, Fermentas) és $6,8 \mu \mathrm{l}$ desztillált vizet adtunk, majd 37 ${ }^{\circ} \mathrm{C}$-on inkubáltuk két órán keresztül. A restrikciós endonukleáz enzimeket húsz percen át $8037{ }^{\circ} \mathrm{C}$ on inkubálással inaktiváltuk, majd az inszertet egy NotI-XbaI emésztett pBKSII+ vektorba klónoztuk. A telepekből alkalikus lízis sel izoláltuk a DNS-t, amelyeket ApaI és SacI emésztéssel ellenőriztünk, a várt termékeket (102 bp inszert nélküli vektor, 132 bp a FLAG inszertet hordozó vektor) $2 \%$ agaróz gélen futtatva különítettük el egymástól. A kapott klónokat T3 és T7 primerek segítségével szekvenálással ellenőriztük, és egy helyes beépülést hordozó plazmidot kiválasztottunk, amelyet pB-FLAG-nek neveztünk el. Az inszert tervezésekor ügyeltünk arra, hogy a FLAG peptidet kódoló szakasz és a két STOP kodon a pBluescriptII plazmid klónozóhelyén található $\beta$-galaktozidáz $\alpha$-fragmensét kódoló géntől különböző leolvasási keretbe kerüljön. A $\beta$ galaktozidáz gén leolvasási keretében így nem találhatóak STOP kodonok, a plazmidról müködőképes $\beta$-galaktozidáz fehérje íródik át, a pB-FLAG alkalmas kék-fehér szelekcióra is.

A rekombináns fehérjéket kódoló baculovírus előállítása: A Nimród fehérjéket kódoló inszerteket polimeráz láncreakcióval állítottuk elő. A felhasznált primerek tartalmazzák a SalI és az XbaI restrikciós endonukleázok hasítóhelyét, valamint a forward primerek egy START (ATG) kodont is:

NimC1 forward: 5'-CAAGTCGACATGATTTGTAACCGATCGCAGG-3'

NimC1 reverse: 5'-CAATCTAGATACCTCGCTGGTTGATGTCTG-3'

NimA forward: 5'-CAAGTCGACATGATACCATTGGGATCAGGACAAAACAG-3'

NimA reverse: 5'-CAATCTAGAGGCCTCACCTCCAACGAATCC-3'

NimB1 forward: 5'-CAAGTCGACATGACGCTGGTGGCATTTCCTG-3'

NimB1 reverse: 5'-CATTCTAGATAGATATCCTTCGCGGCAGTGAC-3'

NimB2 forward: 5'-CAAGTCGACATGAAGACGGCTGGCATCAAGACAC-3'

NimB2 reverse:5'-CAATCTAGACAAACCGGAAGCGCACTCACAG-3'

Draper forward: 5'-GTTGTCGACATGTTGCCGGTAATCCTCATAGC-3'

Draper reverse: 5'-CAATCTAGAGTCGCACTGGCACTTCTGG-3'

Atilla forward: 5'-CAAGTCGACATGCACAGTGCATCGGCCATCAAG-3' 
Atilla reverse: 5'-CAATCTAGATGCACTGACCGCCACAAAG-3';

Templátként teljes RNS mintából reverz transzkripcióval előállított cDNS mintát használtunk a NimA inszert előállításához. A többi inszert előállításához a következő cDNS plazmidokat használtunk templátként: LP05465 (NimC1), GH07762 (NimB1), HL01444 (NimB2), RE50156 (Atilla), IP15264 (Draper). Mindegyik polimeráz láncreakció termékét SalI és XbaI restrikciós endonukleáz enzimekkel emésztettük, majd a pB-FLAG vektorba klónoztuk. Az inszertek szekvenciáját T3 és T7 primerekkel végzett szekvenálással ellenőriztük.

A FLAG taggel ellátott rekombináns fehérjéket baculovírus expressziós rendszerben fejeztettük ki (Bac-to-Bac, Invitrogen). Az inszerteket a pB-FLAG vektorból pFastBacDual vektorba klónoztuk SalI és NotI restrikciós endonukleázok felhasználásával. A pFastBacDual-atilla, pFastBacDual-nimA, pFastBacDual-nimB1, pFastBacDual-nimB2, pFastBacDual-nimC1 és pFastBacDual-draper plazmidokkal DH10Bac kompetens sejteket transzformáltunk, amelyek egy shuttle vektort, más néven bacmidot hordoznak, amely egy fertőzőképes baculovírus genomját tartalmazza. Az inszertek a pFastBacDual vektorokon Tn7 rekombinációs szignálszekvenciák között találhatóak, a shuttle vektor is tartalmaz Tn7 szignálszekvenciákat egy lacZ génben, a DNH10Bac baktériumsejtek pedig kifejezik a szükséges rekombináz enzimet, így a DH10Bac törzsben az inszert a pFastBacDual vektorról a shuttle vektorra rekombinál. A sikeresen rekombinálódott inszert müködésképtelenné teszi a bacmid lacZ génjét, így a sikeres rekombináció termékei kék-fehér szelekcióval azonosíthatóak. A kapott telepek közül a fehér színűekből hetet kiválasztottunk, amelyeket friss kanamicinnel, tetraciklinnel, gentamicinnel, IPTG-vel, X-Gal-lal kiegészített LB agarlemezre szélesztettük és 24 órán át $37^{\circ} \mathrm{C}$-on inkubáltuk. A kinőtt telepek közül kiválasztottuk a fehéreket, amelyekből $2 \mathrm{ml}$ kanamicinnel, tetraciklinnel és gentamicinnel kiegészített LB táptalajba oltottunk le egy-egy kacsnyit, majd ezeket a kultúrákat egy éjszakán át 37 ${ }^{\circ} \mathrm{C}$-on rázattuk. A baktériumszuszpenziókból alkalikus lízissel izoláltuk a plazmid DNS-t, majd az inszert beépülését az izolált bacmid DNS-en végzett polimeráz láncreakcióval ellenőriztük pUC/M13 forward (5'-CCCAGTCACGACGTTGTAAAACG-3') és reverse (5'AGCGGATAACAATTTCACACAGG-3') primerek segtségével. Az inszertet tartalmazó bacmidot hordozó klónokat $60 \mathrm{ml}$ kanamicinnel, tetraciklinnel és gentamicinnel kiegészített folyékony LB táptalajba oltottuk le, majd $\mathrm{OD}_{600}$ 1,5-ig növesztettük a baktériumkultúrákat. A bacmid DNS-t Qiagen Plasmid MIDI KIT segítségével izoláltuk, majd TE pufferben oldottuk fel. 
Fertőzőképes baculovírus előállítása: Az izolált vektor DNS-sel Spodoptera frugiperda lepke eredetü sejtvonalat (Sf9) transzfektáltunk. Az Sf9 sejtekben kifejeződnek a bacmidon kódolt gének, így ezek a transzfektált sejtek fertőzőképes baculovírus részecskéket hoznak létre, táptalajukat friss Sf9 sejtekre helyezve a felülúszóban található vírusrészecskék fertőzik a lepke sejtvonalat. Hatlyukú lemezen (Orange scientific) 60-70\%-os lefedettségig növesztettük az Sf9 lepke sejtvonal sejtjeit TNM-FH táptalajban. A sejteket háromszor megmostuk szérummentes TNM-FH táptalajban. 1,5 $\mu \mathrm{g}$ bacmid DNS-t $33 \mu$ végtérfogat szérummentes TNM-FH táptalajban feloldva összekevertük $33 \mu$ l végtérfogat szérummentes TNM-FH-ban feloldott $12 \mu$ l Cellfectin II reagenssel (Invitrogen), majd tizenöt percen át szobahőmérsékleten inkubáltuk. A DNS oldathoz $300 \mu$ szérummentes TNM-FH táptalajhoz kevertük, majd a megmosott Sf9 sejtekre helyeztük és 12 órán át himbálva inkubáltuk szobahőmérsékleten. A sejteket megmostuk szérummentes TNMFH táptalajban, majd friss táptalajt tettünk a lemezekre és 72 órán át $26{ }^{\circ} \mathrm{C}$-on inkubáltuk. A felülúszó tartalmazta a fertőzőképes baculovírus részecskéket, ez a P1 vírus.

Sf9 sejtek fertőzése és lízise: Az Sf9 sejteket $15 \mathrm{~cm}$ átmérőjű Petri-csészébe oltottuk, majd 50-70\%-os befedettségig növesztettük $25{ }^{\circ} \mathrm{C}$-on. A sejtkultúrát P4-es baculovírussal fertőztük, majd 72 órán át $25{ }^{\circ} \mathrm{C}$-on inkubáltuk. Egy Petri-csésze tartalmát $1800 \mu \mathrm{l}$ Sf9 lízispufferben szuszpendáltuk fel. A mintát háromszor szonikáltuk és fagyasztottuk folyékony nitrogénben, majd centrifugáltuk $\left(18000 \times \mathrm{g} 10\right.$ perc, $\left.4^{\circ} \mathrm{C}\right)$.

Western blot: Megfelelő méretű üveglapok közé öntöttük ki először a 10\%-os futtatógélt (4 $\mathrm{ml}$ akrilamid oldat; 4,5 ml 1M TRIS (pH=8,8); 1,3 ml desztillált víz; $120 \mu 1$ 10\% SDS ; $40 \mu 1$ 10\% APS; $8 \mu \mathrm{l}$ TEMED), amelynek tetejére butanolt rétegeztünk, majd negyven percen át szobahőmérsékleten inkubálva megvártuk, amíg az akrilamid térhálósodik. A butanol felitatása után elkészítettük az 5\%-os gyüjtőgélt (1,31 ml akrilamid; $1 \mathrm{ml} \mathrm{1M} \mathrm{TRIS} \mathrm{(pH=6,8);} \mathrm{6,8} \mathrm{ml} \mathrm{desztillált}$ víz; $80 \mu 1$ 10\% SDS; $40 \mu 1$ 10\% APS; $8 \mu$ TEMED), amelybe fésűt illesztettünk. Az akrilamid térhálósodása után a zsebekbe vittük fel a mintáinkat, majd futtatópufferben addig futtattuk a gélt, amíg a mintapufferben található brómfenolkék frontja egy-két milliméterre meg nem közelítette a gél alsó végét.

A gélben található fehérjéket egy éjszakán át blottoltuk át PVDF membránra, majd a membránt tejporban telítettük. Első ellenanyagként a FLAG epitópot felismerő monoklonális egér ellenanyagot használtuk, második ellenanyagként torma peroxidáz enzimmel konjugált egér immunglobulint felismerő poliklonális kecske ellenanyagot használtunk. A torma peroxidáz enzimet ECL Plus reagenssel mutattuk ki (GE Healthcare-Amersham). 
Primertervezés az RT-PCR reakciókhoz: A templátként szolgáló genomi DNS szakaszok a két primer kapcsolódási pontja között tartalmaznak legalább egy intront, mivel így az RT-PCR végtermékekben különbséget tehetünk a splicingon átesett messenger RNS reverz transzkripciójából származó cDNSről átírt rövidebb, illetve az esetleges genomi DNS szennyezésből származó hosszabb termék között. A kész primereket BLAST elemzésnek vetettük alá, összehasonlítottuk a primerek bázissorrendjeit az ismert Drosophila genom szekvenciákkal, annak érdekében hogy kiszürjük az esetlegesen egynél több helyre is hibridizálni képes, ezáltal fals pozitív eredményekhez vezető primereket. A primerek olvadáspontjait igyekeztünk viszonylag magasra, $50{ }^{\circ} \mathrm{C}$ fölé beállítani, mivel az annealing fázisban használt magas hőmérséklet csökkenti a helytelen primerpárosodással kialakuló komplexek stabilitását.

\section{2. táblázat: A használt primerek és szekvenciáik}

\begin{tabular}{|l|l|l|l|l|l|}
\hline & $\begin{array}{l}\text { Annealing } \\
\text { hőmérséklet }\end{array}$ & $\begin{array}{l}\text { cDNS } \\
\text { termék } \\
\text { mérete }\end{array}$ & $\begin{array}{l}\text { Genomi } \\
\text { DNS } \\
\text { termék } \\
\text { mérete }\end{array}$ & Forward primer (5'-3') & Reverse primer (5'-3') \\
& & & & \\
\hline RP49 & $58^{\circ} \mathrm{C}$ & $316 \mathrm{bp}$ & $378 \mathrm{bp}$ & GCATACAGGCCCAAGATCCGT & CAATCTCCTTGCGCTTCTTG \\
\hline Hemese & $56^{\circ} \mathrm{C}$ & $175 \mathrm{bp}$ & $354 \mathrm{bp}$ & TCAAGTGACCGTCGTTTTC & CCGTTTCACTTGGGGTTGAA \\
\hline eater & $56^{\circ} \mathrm{C}$ & $431 \mathrm{bp}$ & $888 \mathrm{bp}$ & CGGACTCGTATCGGCTCA & CCTGGGTGGTTGGATTCA \\
\hline nimA & $58^{\circ} \mathrm{C}$ & $572 \mathrm{bp}$ & $739 \mathrm{bp}$ & GCAACCGACCAGCAATGAAA & GGCGAAACCACCGAGTAGAG \\
\hline nimB1 & $56^{\circ} \mathrm{C}$ & $1028 \mathrm{bp}$ & $1324 \mathrm{bp}$ & GGCGACATAGAGAATACG & GTGTTGAGATGCTGACTGA \\
\hline nimB2 & $58^{\circ} \mathrm{C}$ & $657 \mathrm{bp}$ & $735 \mathrm{bp}$ & CTGCTCCGAATACCTGTGTCT & CCTTGATGCCGCTCTTGAT \\
\hline nimB4 & $58^{\circ} \mathrm{C}$ & $901 \mathrm{bp}$ & $1120 \mathrm{bp}$ & GGTGCTCCTGGTCCTGTT & GGTCGTCGTATTCTTATCGTATC \\
\hline nimB5 & $56^{\circ} \mathrm{C}$ & $778 \mathrm{bp}$ & $1050 \mathrm{bp}$ & GCGCATTCGTCTAAGTTT & GCACTGGTTGTTGTCCTT \\
\hline nimC1 & $56^{\circ} \mathrm{C} / 58^{\circ} \mathrm{C}$ & $769 \mathrm{bp}$ & $1365 \mathrm{bp}$ & TGGAGTGGTTGGCAGACAAA & ACTTGGGTACGCACTTCTTG \\
\hline nimC2 & $58^{\circ} \mathrm{C}$ & $1063 \mathrm{bp}$ & $1186 \mathrm{bp}$ & AATGCGAGCCCTTCTGTCCCA & ATCCCCCAATCCAATGCCCA \\
\hline nimC3 & $56^{\circ} \mathrm{C}$ & $573 \mathrm{bp}$ & $573 \mathrm{bp}$ & CTGCGGCTGCTGCGTTTAGTG & CCAGCTGCTCGCATCCTTGAATC \\
\hline nimC4 & $58^{\circ} \mathrm{C}$ & $515 \mathrm{bp}$ & $515 \mathrm{bp}$ & GGAGACCACCGAGGACAATAC & CCAACGCCAAGGGATGAAC \\
\hline
\end{tabular}

A használt programok: A dolgozat LibreOffice 3.5.7.2-vel készült, az ábrák szerkesztésére a Gimp 2.8 programot használtuk, a rekombináns fehérjéket a DOG 2.0 (Ren és mtsai., 2009) programmal ábrázoltuk. A DNS szekvenciákat a pDRAW 32 a Serial Cloner 2.6 és a LaserGene DNAStar programmal szerkesztettük. 


\section{Eredmények}

\subsection{A P1 molekula azonosítása}

Munkacsoportunkban a D. melanogaster hemocitáit felismerő monoklonális ellenanyagokat állítottunk elő (Kurucz és mtsai., 2007a). A P1a és P1b ellenanyagok western blot analízisben ugyanazon fehérjemolekula két különböző epitópját ismerik fel. A P1 antigén kizárólag a fagocitáló plazmatociták felületén mutatható ki a vad típusú Oregon-R és a hemocita túltermelő $l(3) m b n-1$ Drosophila törzsekben (Kurucz és mtsai., 2007a) (6. ábra).

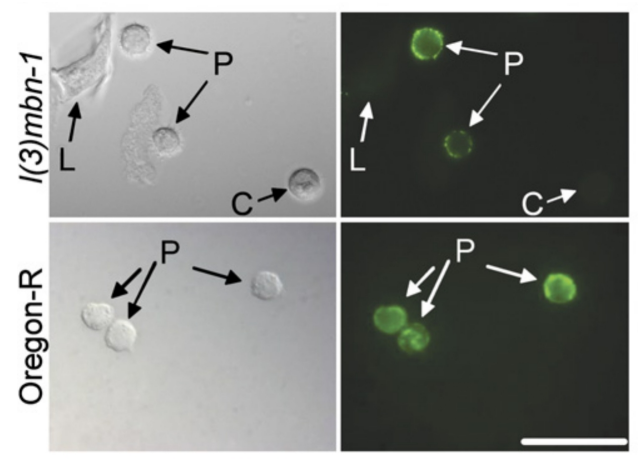

\section{6. ábra: AP1 antigén a plazmatociták sejtmembránjában fejezödik ki}

A Pl fehérjét a vad típusú Oregon-R és az l(3)mbn-1 hemocita túltermelö mutáns hemocitái is kifejezik. A Pl antigént kizárólag a fagocitózisra képes plazmatociták fejezik ki (P), a nem fagocitáló lamellociták (L) és a kristálysejtek (C) felületén nem mutatható ki. (Kurucz és mtsai., 2007b)

A rendelkezésünkre álló P1a és P1b ellenanyagok keverékével l(3)mbn-l hemociták extraktumából immunprecipitálással izoláltuk a 90-100 kDa molekulatömegü P1 antigént, amelyet Western blot elemzéssel azonosítottunk (7. ábra). Az ezüstfestett gélböl kivágott mintában MALDITOF elemzéssel az SZBK Tömegspektrometriai laboratóriuma egy olyan peptidet (VIPYQHR) azonosított, amely kizárólag a prediktált CG8942 gén termékében található meg, amelyet nimC1 vagy nimródCl génnek neveztünk el, a gén terméke a NimródC1 vagy NimC1 fehérje. (Kurucz és mtsai., 2007b) 


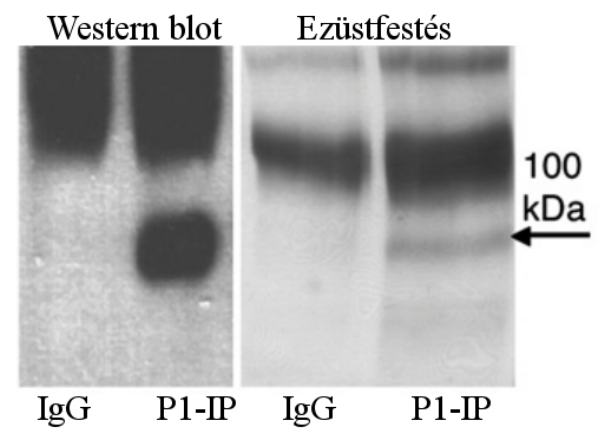

7. ábra: A P1 fehérje izolálása

Az l(3)mbn-1 hemociták lizátumából immunprecipitálással izoláltuk a P1 molekulát, majd az ezüstfestett gélböl kivágott mintában MALDI-TOF elemzést végeztünk. (Kurucz és mtsai., 2007b)

\subsection{A NimC1 fehérjét kódoló nimC1 gén azonosítása}

A P1 antigén tömegspektrometriai elemzésének eredményeként azonosítottunk egy peptidet, amely egyetlen prediktált $D$. melanogaster fehérjében található meg. Annak igazolására, hogy az azonosított peptidet tartalmazó fehérje valóban a nimCl gén terméke a nimCl génterméket rekombináns fehérjeként expresszáltattuk a NimC1 fehérjét ki nem fejező Drosophila Schneider-2 sejtvonalban. A nimCl gént polimeráz láncreakcióval amplifikáltuk, majd réz-szulfáttal indukálható promóter mögé klónoztuk a pMT/V5-HIS vektorba. A pMT/V5-HIS-nimC1 vektorral Schneider-2 sejtvonal sejtjeit transzfektáltuk. Az inszertet nem tartalmazó pMT/V5-HIS vektorral transzfektált Schneider-2 sejtek felszínén ellenanyagainkkal nem mutatható ki a NimC1 fehérje jelenléte, ám a pMT/V5-HIS-nimC1 vektorral transzfektált sejtek felszínén P1a és P1b ellenanyagaink felismerték a vektorba klónozott nimC1 génről kifejeződő NimC1 fehérjét (8. ábra).

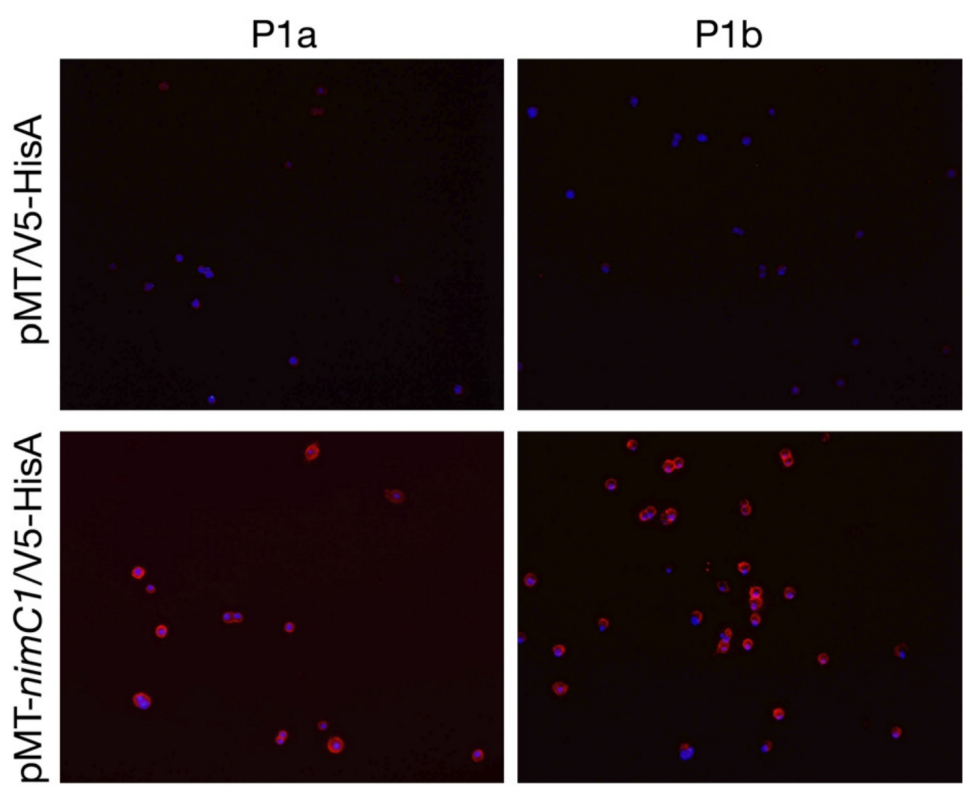

31. oldal 


\section{8. ábra: A rekombináns NimC1 fehérje kifejezödése Schneider-2 sejteken}

A pMT/V5-HIS-nimC1 plazmiddal transzfektált Schneider-2 sejtek felszinén mind a P1a, mind a P1b ellenanyaggal kimutatható a rekombináns NimC1 fehérje, míg az inszertet nem tartalmazó pMT/V5-HIS vektort tartalmazó Schneider-2 sejtek felszínén nem.

A nimC1 gén in vivo azonosításához nimC1 funkcióvesztéses mutánst kívántunk elöállítani, amelyhez az RNS inhibíció módszerét választottuk. Ehhez egy olyan légytörzset állítottunk elö, amely egy UAS promóterrel kifejeztethető konstruktot hordoz a genomjában. A konstrukt a nimC1 gén egy szakaszát tartalmazza fordítottan ismétlödve, így Gal4 forrással meghajtva a beépült transzgénről kettősszálú RNS molekula keletkezik, amely várhatóan RNS inhibícióval csökkenti a nimC1 géntermék mennyiségét. Az UAS-nimC1-IR konstruktot a hemocitákban kifejeződő Hemese-Gal4 konstrukttal (Zettervall és mtsai., 2004), mint Gal4 forrással kifejeztetve csökken a lárvákban szemikvantitatív reverz transzkripció kapcsolt polimeráz láncreakcióval kimutatható nimC1 RNS mennyisége a szülöi törzsekhez, mint kontrollokhoz viszonyítva (9. ábra).

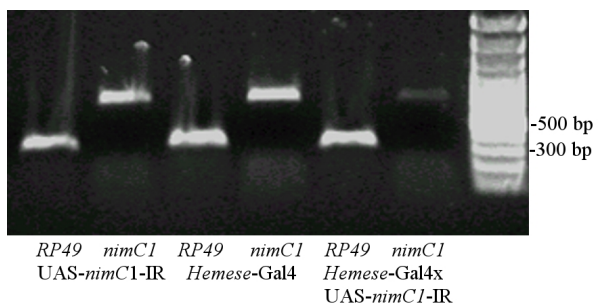

9. ábra: A nimC1 RNS relativ mennyiségének változása a nimC1 RNS inhibíció nyomán

Szemikvantitativ reverz transzkripció kapcsolt polimeráz láncreakciót végeztünk, a nimC1 géntermék mennyiségének megállapitásához. Ahhoz hogy a polimeráz láncreakcióban kapott jel a templáttal arányos mennyiségü legyen, a reakció ciklusszámát huszonötre csökkentettük és a templátot nyolcszorosára hígítottuk. Kontrollként egy minden sejtben kifejezödö, L32 riboszómális fehérjét kódoló rp49 háztartási génre specifikus primerpárt használtunk. Az UAS-nimC1-IR és a Hemese-Gal4 szülöi törzsekben az RP49 géntermék mennyisége megegyezik a Hemese-Gal4xUASnimC1-IR egyedekben mérttel, ám a nimC1 géntermékböl a Hemese-Gal4xUAS-nimC1-IR egyedekben kevesebb található.

Az RNS inhibíció nyomán csökken a hemociták felszínén a NimC1 fehérje mennyisége a szülöi törzsekhez, mint kontrollokhoz képest (10. ábra). E kísérletekkel beláttuk, hogy a P1a és P1b ellenanyagok által felismert P1 antigén a NimC1 fehérje és a NimC1 fehérjét a nimC1 gén kódolja. 


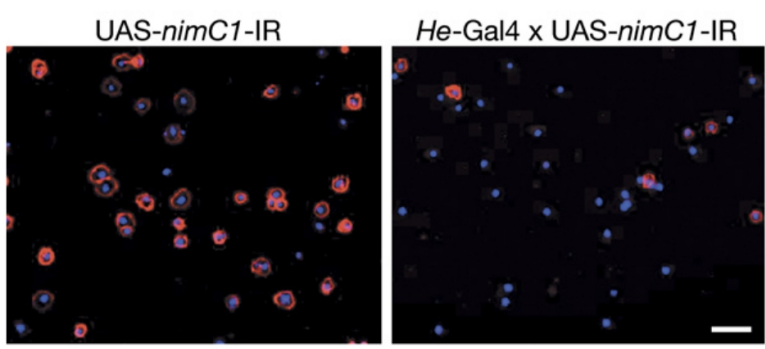

10. ábra: A NimC1 fehérje mennyisége csökken a hemociták felszínén nimC1 RNS inhibíció hatására

Harmadik stádiumú UAS-nimC1-IR és Hemese-Gal4xUAS-nimC1-IR lárvák hemocitáit izoláltuk, majd indirekt immunfluoreszcenciával tettük láthatóvá a sejt felszinén található NimC1 molekulát a Pla és P1b monoklonális ellenanyagaink keverékét, mint elsödleges ellenanyagot és fluoreszcens festékkel jelzett másodlagos ellenanyagot használva. A nimC1 RNS inhibíció csökkenti a NimC1 fehérje mennyiségét a hemociták felszinén.

\subsection{A nimród géncsalád tagjainak transzkripciója}

A nem transzlálódó pszeudogének kizárása érdekében az in silico azonosított nimród génklaszter tagjainak transzkripció szintű kifejeződését vizsgáltuk vad típusú Oregon-R törzs első, második és harmadik stádiumú lárváiban, valamint imágókban, illetve l(3)mbn-1 lárvák izolált hemocitáiban. Kontrollként a korábban általunk azonosított, a nimród géncsalád genomi régiójában található, hemocitákban általánosan kifejeződő hemese génre specifikus primerpárt és a minden sejtben kifejeződő L32 riboszómális fehérjét kódoló rp49 háztartási génre specifikus primerpárt használtuk.

A nimród géncsalád tagjainak kifejeződését reverz transzkripció kapcsolt polimeráz láncreakcióval (RT-PCR) vizsgáltuk. A fals pozitív eredmények kiszürésére minden egyes teljes RNS mintából három templátot készítettünk: Az első templát esetében az izolált teljes RNS-ből reverz transzkripcióval cDNS-t készítettünk, ezt neveztük cDNS templátnak. A második templát esetében az izolált teljes RNS-t DNázI enzimmel kezeltük, majd a DNázI enzim inaktiválása után reverz transzkriptáltuk, ezzel a kezeléssel az esetlegesen meglévő genomi DNS szennyezés mennyiségét csökkentettük. Ezt a mintát neveztük DNáz kezelt mintának. A harmadik templát a megfelelően hígított teljes RNS oldat, amelyet negatív kontrollként használtunk. Ezzel a kísérleti elrendezéssel vizsgálhatóak az intront nem tartalmazó nimC4 és nimC3 gének is, mivel a DNáz kezelés jelentősen csökkenti az izolált RNS esetleges DNS szennyezettségét. 

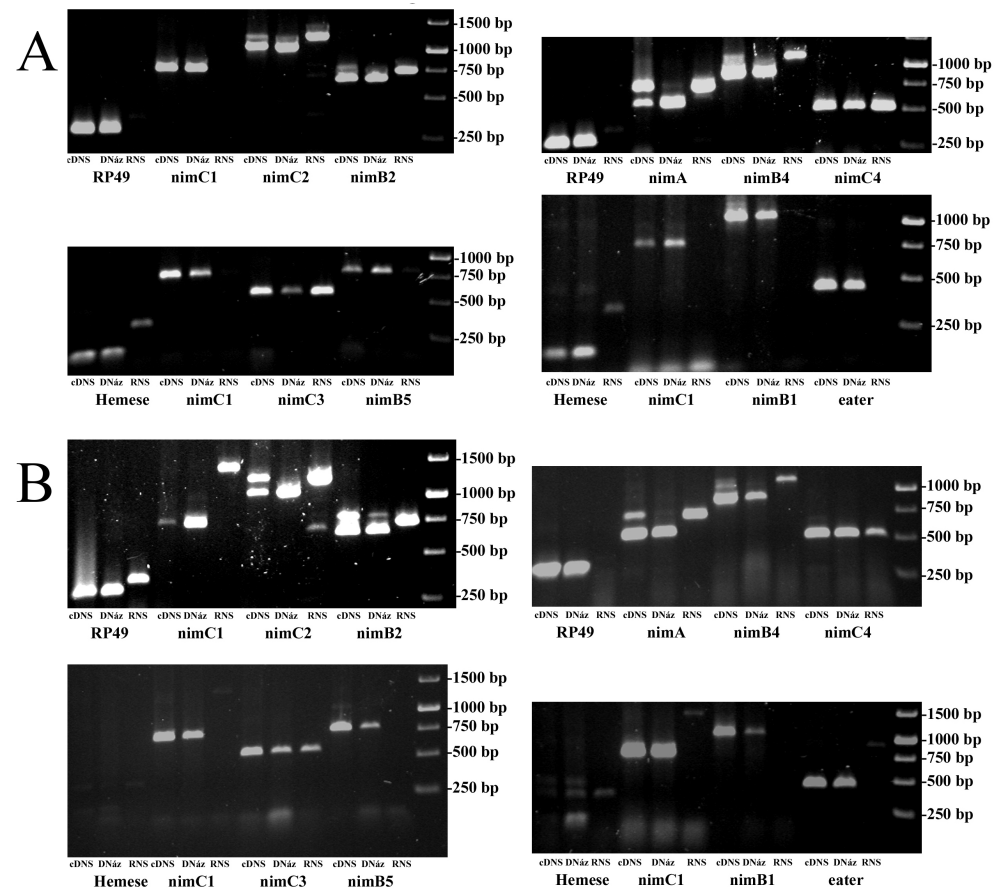

11. ábra: A nimród géncsalád tagjainak kifejezödése vad típusú Oregon-R harmadik stádiumú lárvákban és imágókban

A $\operatorname{nim} A, \operatorname{nim} B 1, \operatorname{nim} B 2, \operatorname{nim} B 4, \operatorname{nim} B 5, \operatorname{nim} C 1, \operatorname{nim} C 2, \operatorname{nim} C 3$, nimC4 és eater gének expressziója egyaránt kimutatható vad típusú Oregon-R harmadik stádiumú lárvákban (A) és imágókban (B), míg a kontrollként használt hemese gén kizárólag a lárvában fejezödik ki.

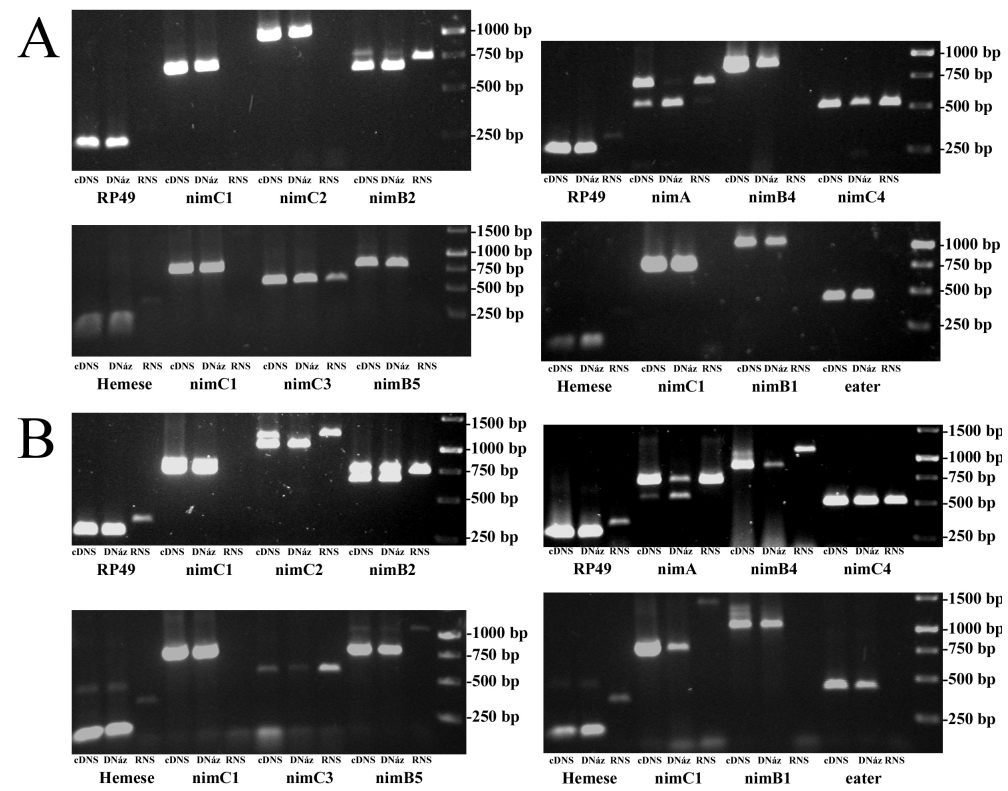

12. ábra: A nimród géncsalád tagjainak kifejezödése vad típusú Oregon-R és l(3)mbn-1 hemocita túltermelö mutáns törzsek harmadik stádiumú lárváiból izolált hemocitákban

A nimA, nimB1, nimB2, nimB4, nimB5, nimC1, nimC2, nimC3, nimC4 és eater gének expressziója egyaránt kimutatható vad típusú Oregon-R harmadik stádiumú lárvákból (A) valamint a hemocita túltermelö l(3)mbn-1 törzs lárváiból származó hemocitákban (B). 
3. táblázat: A nimród gének kifejeződése a vizsgált fejlődési stádiumokban

\begin{tabular}{|l|l|l|l|l|l|l|l|l|l|l|l|l|}
\hline & RP49 & Hem & nimC1 & nimC2 & nim C3 & nim C4 & nimB1 & nimB2 & nimB4 & nimB5 & eater & nim $A$ \\
\hline Oregon-R lárva & + & + & + & + & + & + & + & + & + & + & + & + \\
\hline Oregon-R imágó & + & - & + & + & + & + & + & + & + & + & + & + \\
\hline $\begin{array}{l}\text { Oregon-R } \\
\text { hemocita }\end{array}$ & + & + & + & + & + & + & + & + & + & + & + & - \\
\hline $\begin{array}{l}l(3) m b n-1 \\
\text { lárva }\end{array}$ & $3 .+$ & + & + & + & + & + & + & + & + & + & + & + \\
\hline $\begin{array}{l}l(3) m b n-1 \\
\text { hemocita }\end{array}$ & + & + & + & + & + & + & + & + & + & + & + & - \\
\hline
\end{tabular}

Az eredmények összefoglalása a harmadik táblázatban látható. A nimród géncsalád tagjai RNS szinten kifejeződnek a vad típusú Oregon-R harmadik stádiumú teljes lárvákban és imágókban (11. ábra), míg a kontrollként használt hemese gén a teljes lárvákban kifejeződik, ám nem nyilvánul meg imágókban (11. ábra). A Hemese gén transzkripciós aktivitása (12. ábra) egybevág a Hemese fehérje kifejeződési mintázatával, amely kizárólag a lárva hemocitáin mutatható ki, az imágó hemocitáin nem (Kurucz és mtsai., 2003). A vad típusú Oregon-R hemocitákból készített minták esetén a nimA primerpár a genomi DNS-ből származó, nagyobb méretű termék ezekben a mintákban nagyobb mennyiségben van jelen, mint a rövidebb, cDNS-ből származó termék. Ugyanezt a jelenséget tapasztaltuk $l(3) m b n-1$ mutáns lárvák izolált hemocitáinak vizsgálatakor is, ami a vad típusú, illetve l(3)mbn-1 mutáns teljes lárvák vizsgálatakor nem volt megfigyelhető (13. ábra).

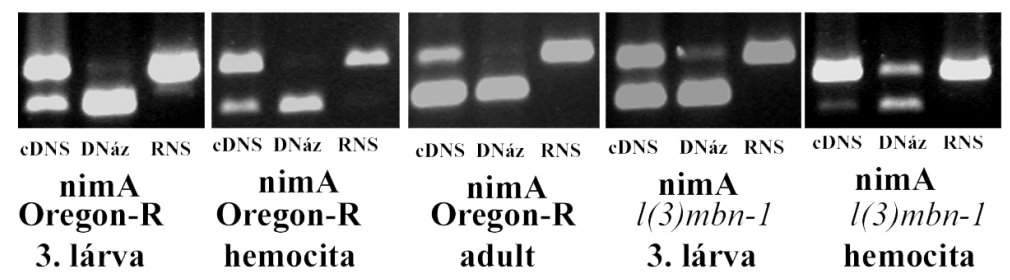

13. ábra: A NimA transzkript a genomi DNS szennyezésböl és a cDNS-böl kimutatható aránya

A teljes lárvákból és imágókból származó mintákban a NimA primerpár használatakor a genomi DNS szennyezésböl származó PCR termék mennyisége körülbelül azonos a cDNS-böl származó termék mennyiségével, míg a hemocitákból származó mintákban a genomi DNS szennyezésböl származó PCR termék nagyobb mennyiségben van jelen, mint a cDNS-böl származó termék.

A fenti a látszólagos ellentmondás feloldására szemikvantitatív RT-PCR-t végeztünk, csökkentve a ciklusszámot. Míg a kontrollként használt RP49 primerekkel már huszonöt ciklusnyi 
polimeráz láncreakció látható terméket eredményezett, a nimA primerek használatával huszonöt ciklus után nem kaptunk értékelhető mennyiségü terméket, így azokkal huszonhét, harminc és harmincöt ciklusnyi polimeráz láncreakciókat is végeztünk (14. ábra).

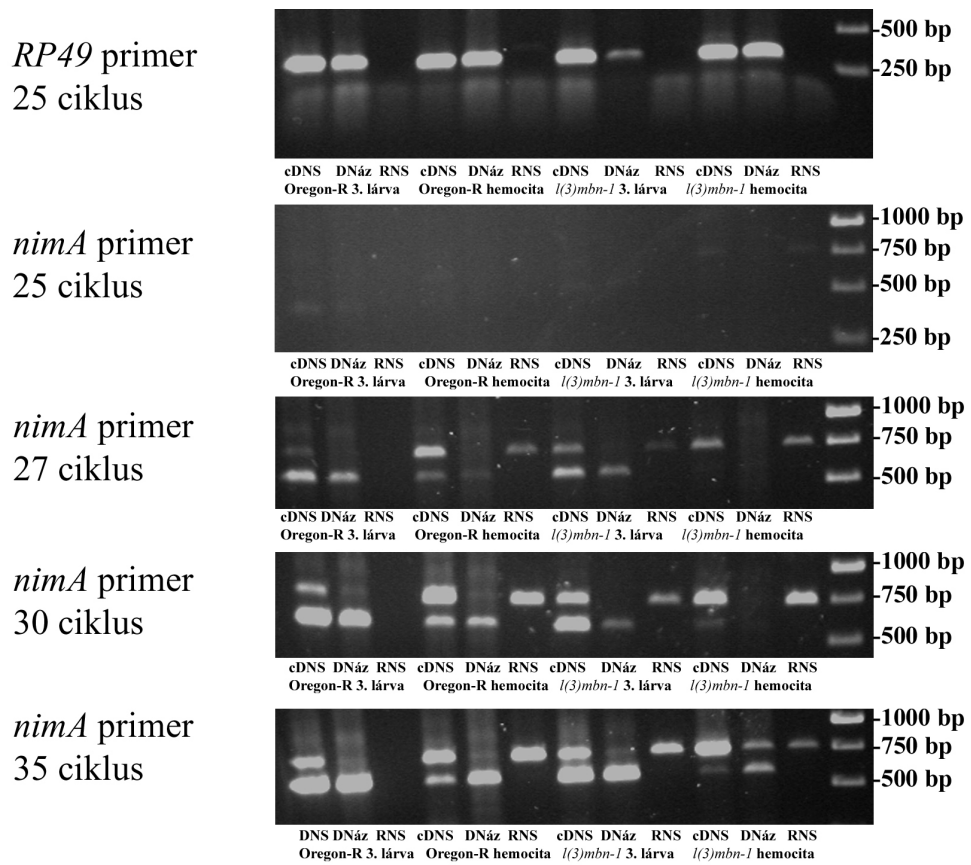

\section{reakciókból}

14. ábra: A NimA primerpár használatával kapott termékek különbözö ciklusszámú PCR

A testi sejtekben általánosan, nagy mennyiségben megtalálható RP49 transzkript már huszonöt PCR ciklus után kimutatható mennyiségü terméket eredményez, míg a nimA messenger RNS csak huszonhét ciklus után hoz létre látható mennyiségü terméket. A vad típusú és az l(3)mbn-1 mutáns teljes lárvákból származó mintákban nagyobb mennyiségü nimA transzkript mutatható ki, mint az izolált hemocita mintákban és az l(3)mbn-1 hemocita mintában kevesebb nimA transzkript mutatható ki, mint a vad típusú, Oregon-R hemocitákból származó mintákban.

Ezekből az eredményekből arra következtettünk, hogy az egyes templátokban eltérő mennyiségű nimA cDNS található. Az Oregon-R és az l(3)mbn-1 egész lárvákból készült mintákban viszonylag nagy mennyiségü nimA cDNS található, a reakció során a cDNS-ből származó jel erősebb, mint a genomi DNS-ből származó jel (13. ábra). Az Oregon-R és l(3)mbn-1 harmadik stádiumú lárvák izolált hemocitáiból származó cDNS mintákban jelentősen kevesebb nimA cDNS található, mint az egész lárvákból származó mintákban ám a vad típusú, Oregon-R hemocitákból készült minta több nimA cDNS-t tartalmaz, mint az l(3)mbn-1 hemocitákból készült minta. A kapott eredményeket azzal magyaráztuk, hogy a $\operatorname{nim} A$ gén nem fejeződik ki hemocitákban, az izolált hemocitákból kapott gyenge jel az állatok kivéreztetésekor a mintát szennyező egyéb szövetdarabokból származik. Mivel a hemocita mintákat a sejtszámra és az RNS mennyiségére is 
normalizáltuk, így ugyanannyi hemocita izolálásához a vad típusú egyedekből körülbelül egy nagyságrenddel többet véreztettünk ki, mint a hemocita túltermelő l(3)mbn-1 mutáns egyedekből, így a vad típusú lárvákból származó mintában az egyéb szöveti szennyezés is több.

Összefoglalva elmondhatjuk, hogy egy kivételével a nimród géncsalád összes vizsgált tagja kifejeződik a vizsgált mintákban (3. táblázat). A kivétel a nimA gén, amely izolált hemocitákban nem mutat transzkripciós aktivitást, de a lárva valamely másik szövetében kifejeződik.

\subsection{A NimC1 szerepe a fagocitózisban}

Meg kívántuk vizsgálni, hogy a $D$. melanogaster fagocita sejtjein megnyilvánuló NimC1 fehérje szerepet játszik -e a fagocitózis folyamatában? A NimC1 fehérje immunválaszban betöltött szerepének funkcióvesztéses vizsgálatához a kettősszálú RNS interferenciával géncsendesített Hemese-Gal4xUAS-nim C1-IR törzsből hemocitákat izoláltunk. Az élő hemocitákat hővel elölt, fluoreszcensen zölden jelölt $S$. aureus baktériumsejtekkel inkubáltuk, majd a hemociták által bekebelezett baktériumok fluoreszcenciáját a FITC emissziós tartományában áramlási citometriával megmértük. A Hemese-Gal4xUAS-nimC1-IR törzs hemocitáin az RNS inhibíció hatására a szülői törzsekhez képest lecsökken a sejtek felszínén kimutatható NimC1 fehérje mennyisége és ezzel párhuzamosan a sejtek $S$. aureus fagocitáló képessége is csökken (15. ábra). Ebből arra következtettünk, hogy az RNS interferenciával előállított NimC1 funkcióvesztéses mutánsában a fagocitózis hatékonysága a NimC1 fehérje sejtfelszíni megnyilvánulásának mértékétől függ.
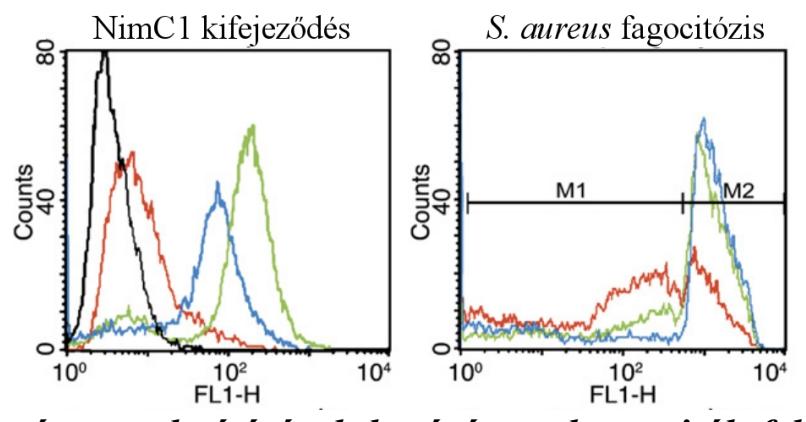

15. ábra: A nimC1 gén csendesítésének hatására a hemociták felszínén csökken a NimC1 fehérje mennyisége és a sejtek $S$. aureus fagocitáló képesség

A nimC1 géncsendesitett Hemese-Gal4xUAS-nimC1-IR törzs hemocitáit (piros hisztogram) illetve a szülői Hemese-Gal4 (zöld), és UAS-nimC1-IR (kék) törzsekböl izolált hemocitákat Pla és $P 1 b$ elsödleges, majd biotinált anti-egér Streptavidin-Cy3 másodlagos ellenanyaggal festve, áramlási citometriával mérve azt tapasztaltuk, hogy Hemese-Gal4xUAS-nimC1-IR törzs hemocitái (piros) kevesebb NimCl fehérjét fejeznek ki és kevesebb S. aureus baktériumot fagocitálnak mint a kontrollként használt szülöi törzsek. Negativ kontrollként indifferens ellenanyaggal festett HemeseGal4xUAS-nimC1-IR hemocitákat (fekete) használtunk. 
A NimC1 fehérje fagocitózisban betöltött szerepének funkciónyeréses vizsgálatához a NimC1 molekulát a Drosophila Schneider-2 sejtvonalban rekombináns fehérjeként fejeztettük ki. A pMT/V5-HIS-nimC1 plazmidot Schneider-2 sejtekbe transzfektáltuk, majd a NimC1 fehérje kifejeződését réz-szulfáttal indukáltuk. A NimC1 fehérjét kifejező Schneider-2 sejteket FITC-cel jelölt baktériummal inkubáltuk, majd áramlási citometriával megmértük a fluoreszcencia intenzitásukat. Negatív kontrollként a pMT/V5-HIS-nimC1 plazmidot hordozó, nem indukált Schneider-2 sejtek szolgáltak, amelyek nem fejezik ki sem az endogén, sem a rekombináns NimC1 fehérjét. A nem fagocitált jelölt baktériumok háttérfluoreszcenciáját tripánkék hozzáadásával küszöböltük ki, amely megakadályozza a FITC molekula emisszióját, így ebben a kísérletben csak a sejtek fagoszómáiban található baktériumok fluoreszkáltak. Azt tapasztaltuk, hogy a rekombináns NimC1 fehérjét kifejező Schneider-2 sejtek fluoreszcencia intenzitása magasabb, mint a kontrollként használt sejteké, ebből arra következtettük, hogy a NimC1 fehérje kifejeződése megnöveli mind az E. coli mind a $S$. aureus baktériumok fagocitózisának hatékonyságát (16. ábra).

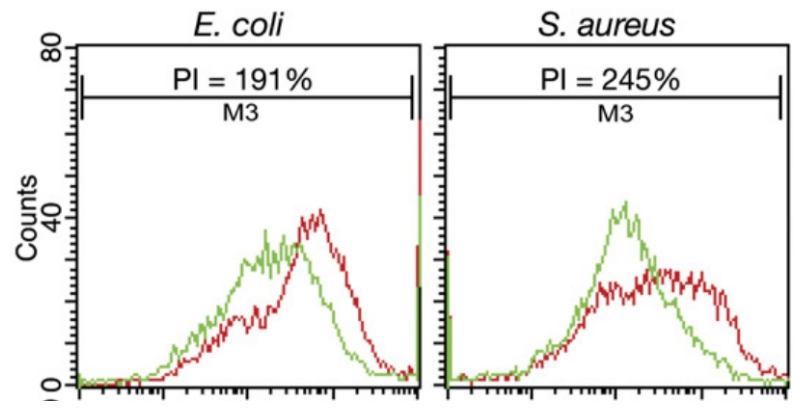

16. ábra: A NimC1 fehérje kifejeztetése növeli a Schneider-2 sejtek fagocitáló képességét

A Schneider-2 sejtek nem fejezik ki a NimC1 fehérjét. A nimC1 gén Schneider-2 sejtekben, egy indukálható vektor (pMTV5-His) segitségével kifejeztetve fokozza a NimC1 fehérjét kifejezö sejtek E.coli és $S$. aureus fagocitáló képességét, (piros) az indukálatlan kontrollhoz képest (zöld).

\subsection{A natív, hemocitákból izolált NimC1 fehérje baktériumkötése}

Az előző fejezetben bemutatott kísérletekből nyilvánvalóvá vált, hogy a NimC1 fehérje a fagocitózis folyamatában játszik valamilyen szerepet. Meg kívántuk vizsgálni, hogy a NimC1 hozzájárul-e a fagocitózis első lépéséhez, a mikróbák felismeréséhez és megkötéséhez. A NimC1 fehérje baktériumkötésének vizsgálatához a hemocita túltermelő l(3)mbn-1 harmadik stádiumú lárvákból hemocitákat izoláltunk, majd ezeket nemionos detergenst (NP-40) tartalmazó lízispufferben szonikálva, majd folyékony nitrogénben fagyasztva NimC1 és a fagocitózis szempontjából indifferens, a tokképző lamellocitákon megnyilvánuló Attila fehérjét (Kurucz és mtsai., 2007b, Honti és mtsai., 2009) is tartalmazó lizátumot állítottunk elő. Ezzel a lizátummal hővel inaktivált, zöld fluoreszcens festékkel (FITC) jelölt baktériumsejteket kezeltünk, majd a 
baktériumsejteket megmostuk és a NimC1 fehérjét felismerö P1a és P1b monoklonális ellenanyag (mAb) keverékkel, valamint negatív kontrollként az Atilla fehérjét felismerő L1a, L1b mAb keverékkel festettük. Az egér mAb ellenanyagok jelenlétét a baktériumokon távoli vörös fluoreszcens festékkel (Alexa 633) jelölt poliklonális anti-egér ellenanyaggal mutattuk ki. A mintákat áramlási citometriával mértük, a baktériumsejteket zöld fluoreszcenciájuk alapján azonosítottuk, majd a zölden fluoreszkáló részecskék távoli vörös fluoreszcenciáját határoztuk meg. Amennyiben a hemocita lizátumban található NimC1 fehérje kötődik a baktériumsejtekhez, a zölden fluoreszkáló részecskék távoli vörös fluoreszcenciája megemelkedik.

Elsőként a NimC1 fehérje Gram-negatív E. coli és Gram-pozitív S. epidermidis kötését vizsgáltuk. A baktériumkötés mértékének meghatározására a NimC1 specifikus ellenanyagokkal festett minta fluoreszcencia-intenzitásának számtani közepének (MFI) és az Atilla specifikus ellenanyagokkal festett negatív kontroll fluoreszcencia-intenzitásainak számtani közepének hányadosát választottuk és ezt neveztük relatív fluoreszcencia intenzitásnak (RMFI). A kapott MFI értékeket statisztikai elemzésnek vetettük alá, azokat a kölcsönhatásokat neveztük baktériumkötésnek, ahol a Student $t$-teszt eredménye öt századnál alacsonyabb, azaz a NimC1 ellenanyaggal festett minták MFI értékei szignifikánsan különböznek a kontroll MFI értékektől. Azt tapasztaltuk, hogy a hemocita lizátummal kezelt, NimC1 ellenanyaggal festett E. coli baktériumok fluoreszcencia intenzitása a kontrollhoz képest több mint kétszeresére emelkedett és a NimC1 ellenanyaggal festett minták fluoreszcencia intenzitása szignifikánsan különbözött a kontroll fluoreszcencia intenzitásától (RMFI=2,26 $\pm 0,17$; $=0,002 ; n=5)$. Ebből arra következtettünk, hogy a hemocita lizátumban található NimC1 fehérje a Gram-negatív E. coli baktériumsejtek felszínéhez kötődik (17. ábra). A NimC1 fehérje S. epidermidis kötését vizsgálva azt tapasztaltuk, hogy a baktériumsejtek fluoreszcencia intenzitása nem különbözik szignifikánsan a negatív kontrollétól (RMFI=0,97 $\pm 0,09 ; p=0,397 ; n=5$ ), ebböl arra következtettünk, hogy a NimC1 nem kötödik Grampozitív S. epidermidis sejtekhez (17. ábra). 

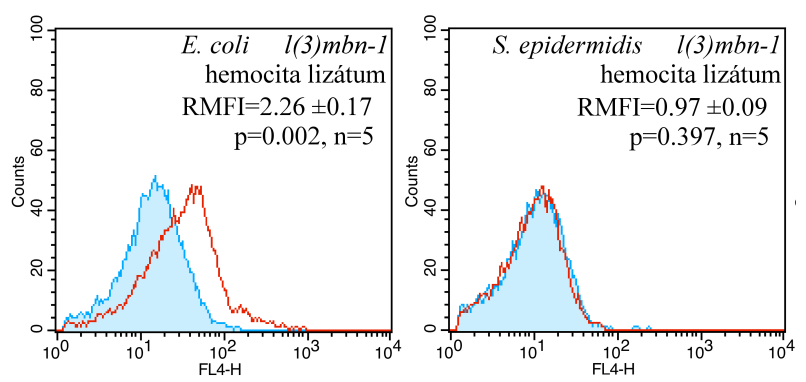

\section{7. ábra: A nimC1 fehérje kötödése E. coli és S. epidermidis baktériumokhoz}

A hemocita lizátummal kezelt, NimCl elsödleges és távoli vörös tartományban fluoreszcensen jelölt anti-egér másodlagos ellenanyaggal festett E. coli távoli vörös tartományban mért fluoreszcencia intenzitása magasabb az Atilla elsödleges ellenanyaggal festett negatív kontrollénál, jelezve, hogy a NimC1 fehérje kötödik az E. coli baktériumsejtekhez, míg az Atilla fehérje nem. A hemocita lizátummal kezelt S. epidermidis MFI értéke közel azonos mindkét ellenanyaggal festve, jelezve, hogy egyik fehérje sem kötödik az S. epidermidis sejtekhez.

A NimC1 baktériumkötésének optimális beállításához harminc, hatvan, száznyolcvan percen, valamint egy éjszakán át inkubáltunk $E$. coli sejteket $l(3) m b n-1$ hemociták lizátumában, majd az így kezelt mintákat az NimC1 fehérjét felismerő elsődleges ellenanyaggal festettük. Eredményeink szerint a NimC1 festett minta MFI értéke az inkubációs idő növekedése során eljut a telítésig (18. ábra). A továbbiakban minden kísérletben éjszakán át inkubálást alkalmaztunk.

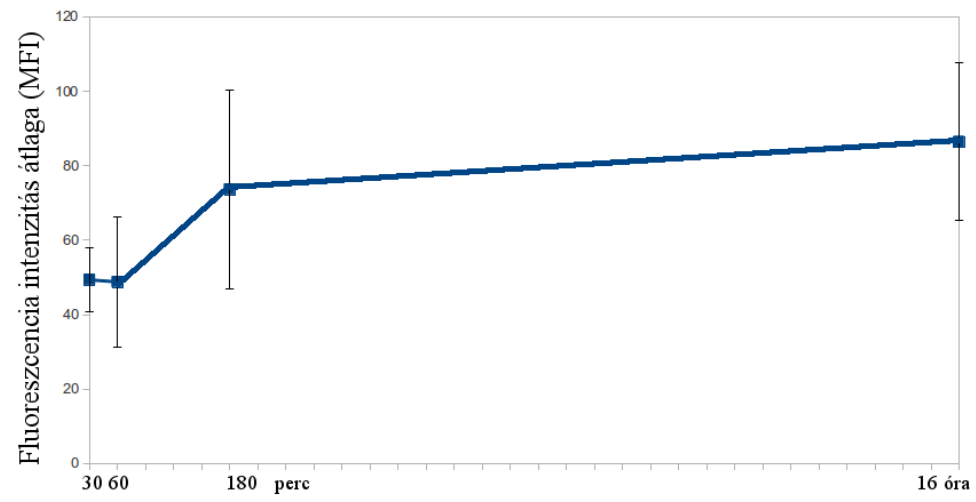

18. ábra: A NimC1 baktériumkötésének idöfüggése

Hövel elölt, FITC-jelölt E. coli baktériumokat inkubáltunk 30, 60, 180 percen és egy éjszakán át hemocita lizátumban. Az ábrán az egyes minták MFI értékét ábrázoltuk.

A NimC1 baktériumkötés negatív kontrolljaként a Hml-Gal4.4, 2XUAS-EGFP; l(3)mbn-1 lárvákból származó hemociták lizátumát használtuk. A Hml-Gal4.4, 2XUAS-EGFP; l(3)mbn-1 törzs a második kromoszómáján egy spontán keletkezett háttérmutációt hordoz, amelynek hatására hemocitái felületén a P1a és P1b ellenanyagainkkal nem mutatható ki a NimC1 fehérje jelenléte (19. ábra). A Hml-Gal4.4, 2XUAS-EGFP; l(3)mbn-1 hemociták lizátumával kezelt, NimC1 ellenanyaggal festett minta fluoreszcencia intenzitása hasonló az Atilla kontrolléhoz (RMFI=0,89 $\pm 0,17 ; \mathrm{p}=0,112 ; \mathrm{n}=4)$ (20. ábra). Hasonlóan nem mutattunk ki baktérium kötődést abban az estben, 
amikor a baktériumokat hemocita lizátum helyett pufferrel kezeltük (RMFI $=0,96 \pm 0,14 ; p=0,343$; $\mathrm{n}=5)$ (20. ábra).
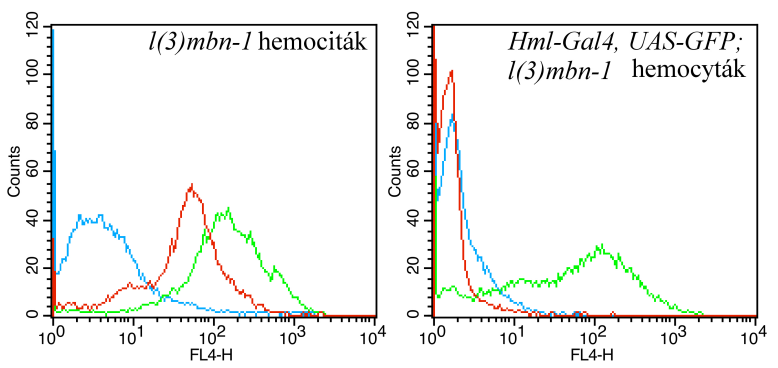

19. ábra: A Hml-Gal4.4, 2XUAS-EGFP; l(3)mbn-1 hemociták nem fejezik ki a NimC1 fehérjét

Harmadik stádiumú lárvákból izoláltunk élő hemocitákat l(3)mbn-1 és a Hml-Gal4.4, 2XUAS-EGFP; l(3)mbn-1 homozigóta egyedekböl. A hemocitákat NimC1 ellenanyaggal festettük (piros), negativ kontrollként az emberi CD45 fehérjét felismerő T2/48 ellenanyagot (kék), pozitív kontrollként a D. melanogaster minden hemocitáján kifejezödö Hemese fehérjét felismerö ellenanyagot (zöld) használtuk. Másodlagos ellenanyagként Alexa 633 fluorokrómmal jelölt, távoli vörös tartományban emittáló anti-egér ellenanyagot használtunk. Mindkét törzs hemocitáin kimutatható a Hemese fehérje, a NimC1 azonban kizárólag az l(3)mbn-1 hemocitákon fejezödik ki.
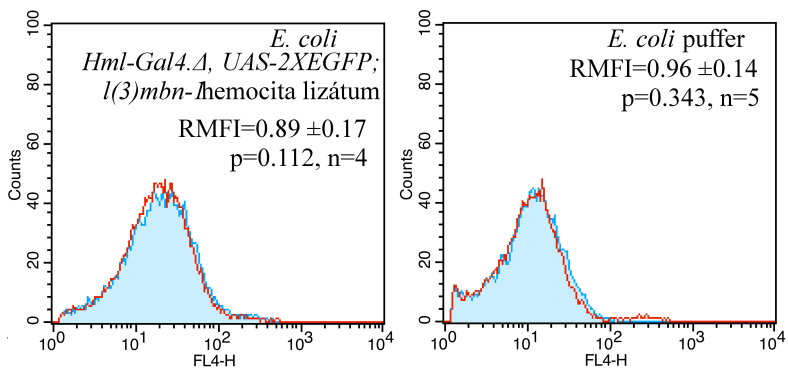

20. ábra: Baktériumkötési negatív kontroll kísérletek

A Hml-Gal4.4, 2XUAS-EGFP; l(3)mbn-1 hemociták lizátumával és pufferrel inkubált E. coli sejteken nem mutatható ki a NimC1 fehérje jelenléte.

Megvizsgáltuk a NimC1 fehérje különböző baktériumtörzsekhez kötődését és azt tapasztaltuk, hogy a NimC1 fehérje az E. coli-hoz hasonlóan kötődik a Gram-negatív $S$. marcescens (RMFI=2,403 $\pm 0,436 ; \mathrm{p}=0,0002 ; \mathrm{n}=4)$, Xanthomonas campestris $(\mathrm{RMFI}=2,053 \pm 0,603 ; \mathrm{p}=0,01$; n=4), Pseudomonas aeruginosa (RMFI=1,867 $\pm 0,206 ; \mathrm{p}=0,003 ; \mathrm{n}=4)$ baktériumtörzsekhez. Az E. coli esetében megfigyeltnél alacsonyabb RMFI értékkel, ám szignifikánsan kötődik a NimC1 molekula a Gram-pozitív B. cereus var. mycoides szervezethez (RMFI=1,463 $\pm 0,161 ; \mathrm{p}=0,028$; n=4). A NimC1 molekula nem kötődik Gram-pozitív M. luteus (RMFI=1,005 $\pm 0,104 ; \mathrm{p}=0,493$; $\mathrm{n}=4$ ) és B. subtilis (RMFI=1,195 $\pm 0,096 ; \mathrm{p}=0,13 ; \mathrm{n}=4)$ baktériumokhoz (21. ábra). 


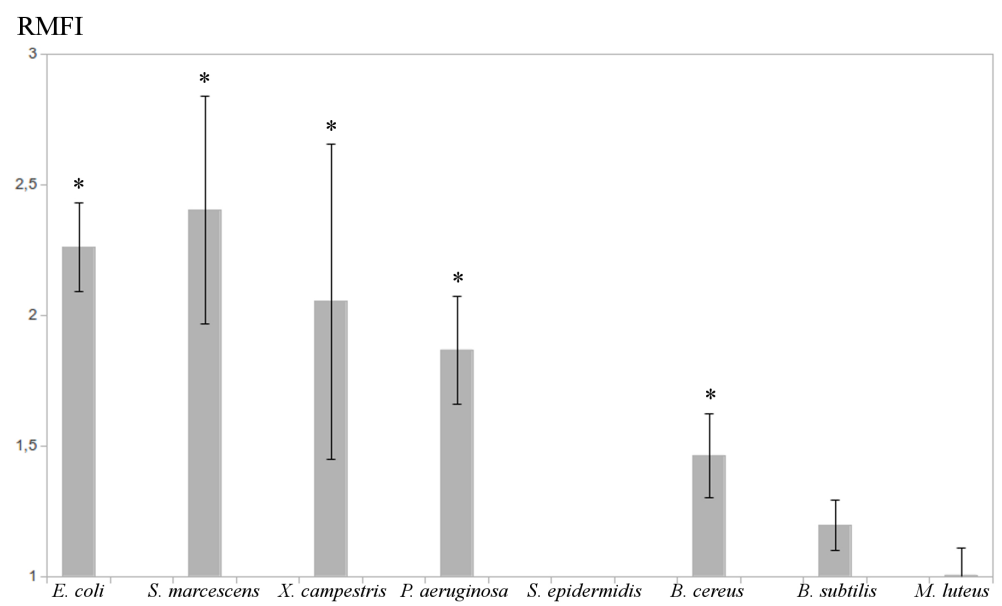

\section{1. ábra: A NimC1 kötődése különbözö baktériumtörzsekhez}

A NimC1 fehérje különbözö baktériumokhoz való kötödését összehasonlitva, a csillaggal jelölt Gram-negativ E. coli, S. marcescens, X. campestris P. aeruginosa és a Gram-pozitív B. cereus mutat szignifikáns NimC1 kötést.

\subsection{A NimC1 fehérje ligandjának vizsgálata}

Miután beláttuk, hogy a NimC1 fehérje kötődik az E. coli baktériumhoz, meg kívántuk vizsgálni, mi az a ligand, amelyet felismer a baktérium felületén. Elsőként E. coli lizátumot készítettünk, amit hemocita lizátummal előinkubálva azt tapasztaltuk, hogy a baktérium lizátum csökkentette a NimC1 kötődését a hővel elölt baktériumsejtekhez, jelezve, hogy az E. coli lizátum valamely alkotóeleme kompetál a NimC1 kötőhelyekért. A NimC1 fehérje ligandjának meghatározásához peptidoglikánnal (PG) és lipopoliszacchariddal (LPS) előinkubált hemocita lizátummal végeztünk kompetíciós baktériumkötési kísérleteket, ám azt tapasztaltuk, hogy sem a PG sem az LPS jelenléte sem csökkenti a NimC1 baktériumkötési kapacitását (22. ábra). Ebböl arra következtettünk, hogy egyik sem ligandja a NimC1-nek, hiszen nem kompetálnak a molekula kötőhelyeiért.
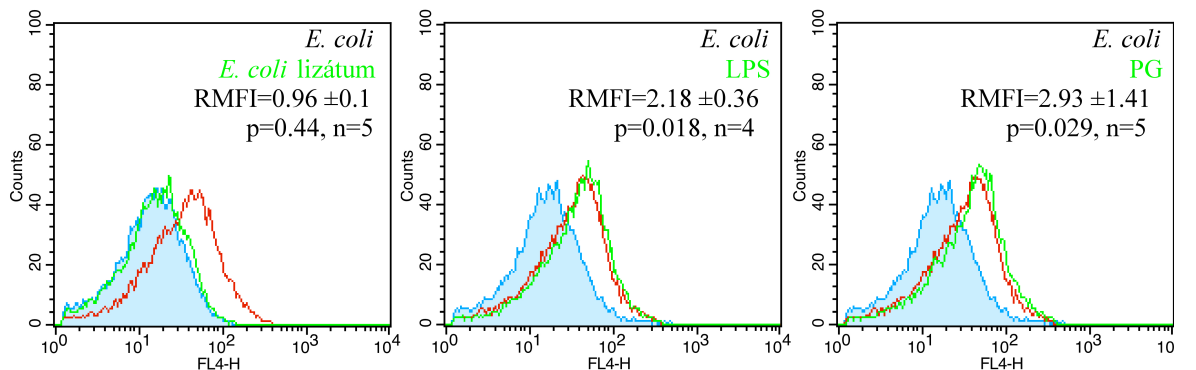

22. ábra: A NimC1 baktériumkötésének kompetíciós vizsgálata E. coli lizátum, lipopoliszaccharid vagy peptidoglikán jelenlétében

Az ábrákon piros hisztogram jelöli a hemocita lizátummal kezelt NimC1 ellenanyaggal festett baktériumsejtek távoli vörös fluoreszcenciáját, a kontrollhoz viszonyítva (kék). E. coli lizátum hozzáadása gátolja a NimC1 baktériumkötését (A, zöld), ám a hemocita lizátumhoz $200 \mu \mathrm{g} / \mathrm{ml}$ LPS 
(B, zöld) vagy $153 \mu \mathrm{g} / \mathrm{ml} P G(C$, zöld) hozzáadása nem csökkenti a NimC1 ellenanyaggal festett E. coli sejtek távoli vörös fluoreszcenciáját.

Az LPS molekulát, mint lehetséges NimC1 ligandot egy másik módszerrel is megvizsgáltuk, mivel nem lehet kizárni, hogy a kereskedelmi forgalomban kapható LPS az izolálás során valamilyen kémiai módosításon esik át, amelynek nyomán már nem képes kötődni hozzá a NimC1 molekula. Az LPS molekula felépítésében központi szerepet játszik a hidrofób Lipid A molekula, amelyhez hidrofil oligoszaccharidok kapcsolódnak kovalens kötésekkel. A cukormolekulák a Lipid A sorozatos, különböző membránkötött glikoziltranszferáz enzimek által katalizált glikozilációjával épülnek föl. Az egyes glikozilációs lépéseket katalizáló enzimek ismertek, funkcióvesztéses mutánsaik hozzáférhetőek. Megvizsgáltuk a NimC1 molekula kötődését a WaaC mutáns E. coli törzshöz, amely a sejtfalában található Lipid A molekulát egyetlen 3-deoxi-D-manno-okt-2uloszonsav glikozilálja, így ez a baktériumtörzs a vad típusúhoz képest csonkolt LPS molekulát épít be a sejtfalába. Mivel a WaaC törzset inszerciós mutagenezissel hozták létre, egy kanamicin rezisztanciagént tartalmazó kazettát építve a vad típusú WaaC gén helyére, szükséges volt az eddig használt vad típusú E. coli törzs mellett egy újabb kontroll alkalmazása. Ahhoz, hogy kiküszöbölhessük a kanamicin rezisztancia esetleges kísérleti eredményt torzító hatásait, negatív kontrollként használtuk az ugyanebből a törzsgyüjteményből származó LacY törzset, amely ugyanezt a kanamicin reziztanciagént hordozza a laktóz-permeáz enzimet kódoló LacY génjében, így vad típusú LPS molekulát épít a sejtfalába (Chen és Coleman, 1993; Heinrichs és mtsai., 1998; Qimron és mtsai., 2006). Eredményeink szerint a nimC1 molekula mindkét E. coli törzshöz hasonlóan kötődik (23. ábra), valószínüsítve, hogy az LPS valóban nem a NimC1 receptor ligandja.

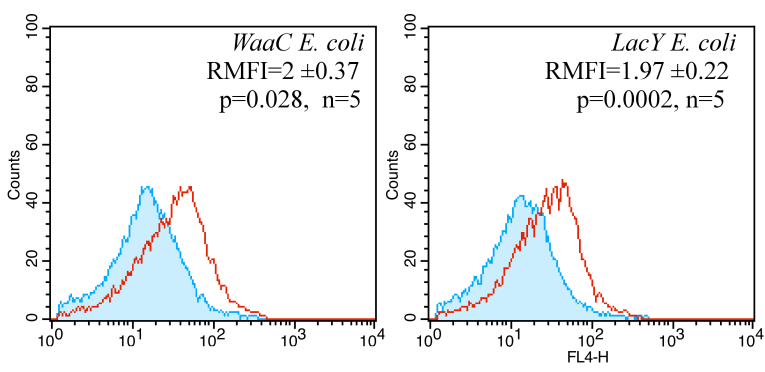

23. ábra: NimC1 kötödése vad típusú, WaaC és LacY mutáns E. coli törzsekhez

A trunkált LPS molekulát kifejezö WaaC baktériumtörzshöz és az azonos módszerrel létrehozott LacY mutánshoz hasonlóan kötödik a NimC1 molekula, valószinüsítve, hogy az LPS nem ligandja a NimC1 receptornak. Piros hisztogrammok jelölik a NimC1, kékek a kontroll ellenanyaggal festett mintákat. 
A NimC1 ligand kémiai természetének meghatározásához fenolprecipitálással és Proteináz K emésztéssel eltávolítottuk a fehérjéket az E. coli lizátumból, majd a fehérjementesített lizátummal gátoltuk a NimC1 baktériumkötését. Azt tapasztaltuk, hogy mind a fenolprecipitált mind a Proteináz K kezelt E. coli lizátum kevésbé gátolja a NimC1 baktériumkötését (24. ábra) mint a kezeletlen, amiböl arra következtettünk, hogy a fenolprecipitálás és a Proteináz K emésztés egyaránt eltávolítja az baktérium lizátumból a NimC1 ligandját, ami a ligand fehérje-természetére utal.
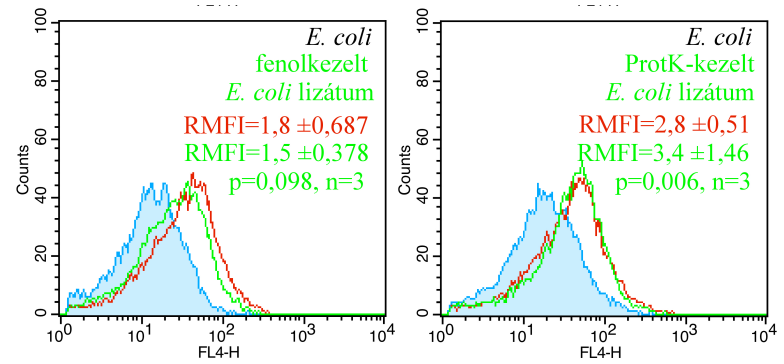

24. ábra: A fehérjék eltávolítása megszünteti az, E. coli lizátum kompetícióját a NimC1 kötőhelyekért

A kezeletlen hemocita lizátumból származó NimC1 molekula baktériumkötése látható a piros hisztogramokon, a negatív kontrollhoz viszonyitva (kék). A fenolprecipitált (zöld) és a Proteináz K enzimmel kezelt (zöld) baktérium lizátum kevéssé gátolja a NimC1 baktériumkötését, jelezve, hogy a NimC1 ligandja fehérjetermészetü.

\subsection{A rekombináns Nimród fehérjék baktériumkötése}

Mivel a Nimród fehérjék közül egyedül a NimC1 fehérjét felismerő ellenanyagokkal rendelkeztük, további Nimród fehérjék baktériumkötésének vizsgálatához a NimC1, NimA, NimB1, NimB2 fehérjék FLAG epitóppal ellátott extracelluláris doménjeit rekombináns fehérjeként termeltettük meg így ezen fehérjék baktériumkötését anti-FLAG ellenanyag segítségével ugyanabban a kísérleti rendszerben vizsgálhattuk, mint a NimC1 fehérjéét. Negatív kontrollként az Atilla fehérje FLAG epitóppal ellátott extracelluláris doménjét fejeztettük ki, pozitív kontrollként pedig a már korábban baktériumkötő fehérjeként leírt Draper fehérje FLAG epitóppal kiegészített extracelluláris doménje szolgált. A fehérjék kifejeztetésére a baculovírus alapú Bac-to-Bac expressziós rendszert választottuk. 
A lepke sejtek lizátumában a rekombináns fehérjék jelenlétét anti-FLAG ellenanyag segítségével western blot analízissel mutattuk ki (25. ábra). Méréseink alapján a rekombináns Nimród fehérjék molekulatömege kissé nagyobbnak bizonyult az aminosav-szekvenciájuk alapján számított molekulatömegnél, amit feltehetőleg poszt-transzlációs módosítások okozhatnak, legvalószínűbben a fehérjék glikozilációja, amire a szekvenciákban található prediktált glikozilációs helyek jelenléte is utal.

A

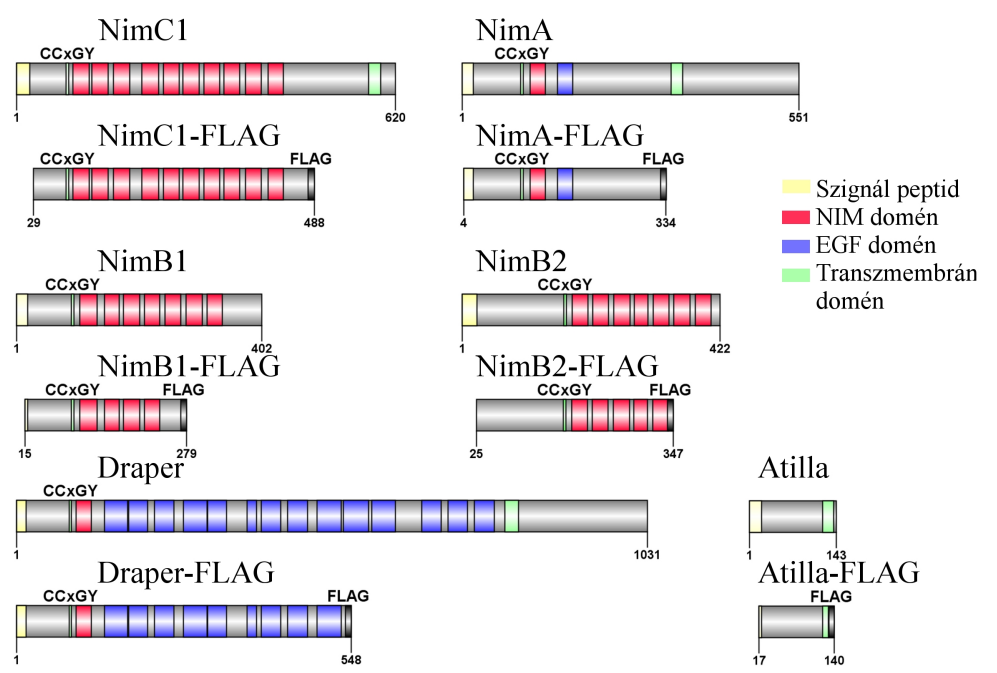

B

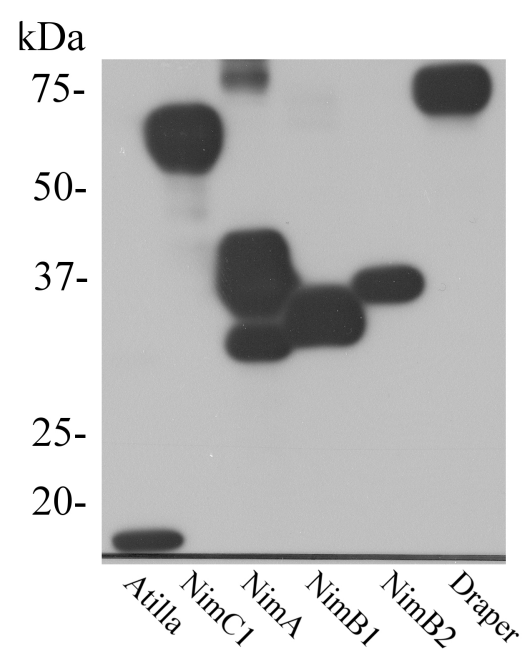

25. ábra: A kifejeztetett fehérjék és western blot elemzésük

Az A oldalon a rekombináns Nimród fehérjék doménszerkezete látható. Sárgával jelöltük a szignál peptideket, pirossal a NIM doméneket, kékkel az EGF doméneket, zölddel a transzmembrán doméneket, feketével a FLAG epitópokat. Az ábra B oldalán a kifejeztetett rekombináns fehérjék Western blot elemzése látható, a rekombináns fehérjék aminósavszekvenciája alapján számitott molekulatömege közel azonos a western blot során mért molekulatömegükkel. Atilla (mért molekulatömeg: $15 \mathrm{kDa}$; számított molekulatömeg: 13,6 kDa); NimC1 (mért molekulatömeg: 52-60 kDa; számított molekulatömeg: 50,4 kDa); NimA (mért molekulatömeg: 32, 35-42, $65 \mathrm{kDa}$; számított molekulatömeg: 36,3 kDa); NimB1 (mért molekulatömeg: 30-39 kDa; számított molekulatömeg: 30,1 kDa); NimB2 (mért molekulatömeg: 34-37 kDa; számított molekulatömeg: 35,3 kDa); Draper (mért molekulatömeg: 60-80 kDa; számított molekulatömeg: 59,5 kDa);

A rekombináns fehérjék baktériumkötő képességét a hemocitákból származó NimC1 fehérjéhez hasonlóan vizsgáltuk. A fehérjéket kifejező lepke sejtek lizátumával hővel elölt, FITCjelölt baktériumsejteket kezeltünk, majd a baktériumokat a FLAG epitópot specifikusan felismerő, egér IgG elsődleges ellenanyaggal és az egér ellenanyagot specifikusan felismerő, a távoli vörös tartományban fluoreszkáló Alexa 633 fluorokrómmal jelölt másodlagos ellananyaggal festettük, majd a baktériumok távoli vörös fluoreszcencia intenzitását áramlási citometriával mértük. A NimA NimB1, NimB2, NimC1 és Draper fehérjéket kifejező $\mathrm{Sf9}$ sejtek lizátumával $E$. coli és $S$. epidermidis baktériumokat kezeltünk, majd az áramlási citometriás méréssel kapott MFI értékekből 
kiszámítottuk az egyes minták RMFI értékeit, az Atilla fehérjét termelő Sf9 sejtlizátummal kezelt baktériumokhoz, mint negatív kontrollhoz viszonyítva.

Az E. coli baktériumsejteket a rekombináns NimC1 fehérjét kifejező Sf9 sejtek lizátumával illetve a rekombináns Atilla fehérjét kifejező Sf9 sejtek lizátumával kezeltünk, majd az Atilla, a NimC1, illetve az anti-FLAG ellenanyaggal festettük. A hat minta összehasonlítása során azt tapasztaltuk, hogy a rekombináns NimC1 fehérjével kezelt baktériumsejtek fluoreszcencia intenzitása mind az anti-NimC1 mind az anti-FLAG ellenanyaggal festve magasabb a kontrollénál, míg a rekombináns Atilla fehérjével kezelt sejtek fluoreszcencia intenzitása az ellenanyagokkal festve alacsony maradt (26. ábra). Ebből arra következtettünk, hogy a rekombináns NimC1 fehérje a hemocitákból származó natív NimC1 fehérjéhez hasonlóan kötődik az E. coli sejtekhez és ez a kötődés mind a NimC1 fehérjét felismerő ellenanyagokkal mind a FLAG-taget felismerő ellenanyaggal kimutatható.
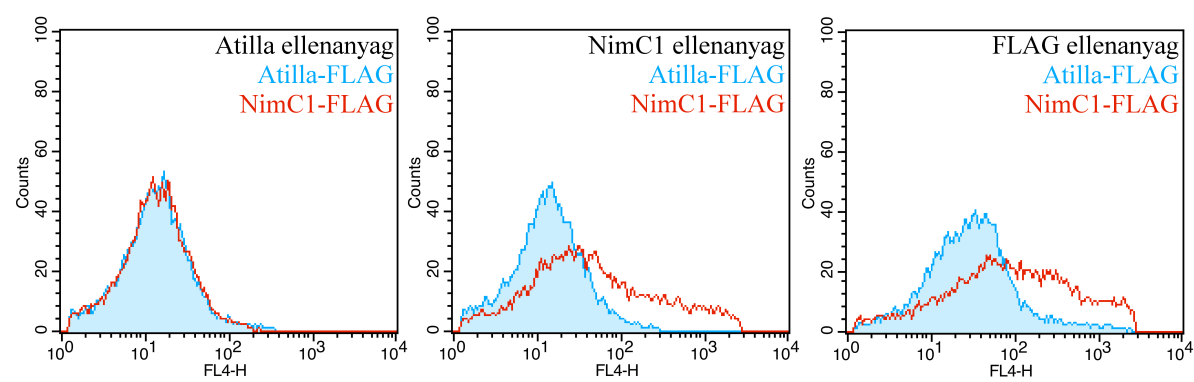

26. ábra: A rekombináns NimC1 fehérje baktériumkötése anti-NimC1 és anti-FLAG ellenanyaggal is kimutatható

A rekombináns NimCl fehérjét kifejezö Sf9 sejtek lizátumával FITC jelölt E. coli baktériumsejteket kezeltünk. A baktériumokat a NimC1 fehérjét felismerö és a FLAG epitópot felismerö ellenanyaggal valamint negativ kontrollként Atilla fehérjét felismerö ellenanyaggal festettük.

A továbbiakban a Draper, NimB1, NimB2, NimA rekombináns fehérjék baktériumkötését is megvizsgáltuk és azt tapasztaltuk, hogy a NimA, NimB1, NimB2 NimC1 és Draper fehérjék szignifikánsan kötődnek az E. coli baktériumokhoz (27. ábra). A NimC1, a Draper és a NimB1 fehérjék esetében magasabb RMFI értékeket mértünk, míg a NimA és a NimB2 esetében alacsonyabbakat. A Gram-pozitív S. epidermidis baktériumsejtekhez a vizsgált rekombináns fehérjék közül egyedül a NimB1 kötődött szignifikánsan. A kísérleteink alapján a rekombináns NimC1 fehérje $(\mathrm{RMFI}=3,539 \pm 1,021 ; \mathrm{p}=0,007 ; \mathrm{n}=5)$ a pozitív kontrollként használt Draperhez $(\mathrm{RMFI}=3,224 \pm 1,61 ; \mathrm{p}=0,024 ; \mathrm{n}=5)$ hasonló komplexet alakít ki $E$. coli baktériumokkal, ám a kötés RMFI értéke magasabb, mint a natív, hemocitákból származó NimC1 fehérjéé (RMFI=2,256 $\pm 0,166 ; p=0,002 ; n=5)$. Ebböl arra következtethetünk, hogy a baktériumkötés hatékonysága nem 
egyenesen arányos a fehérjemolekula NIM doménjeinek a számával, hiszen a rekombináns NimC1 a natív fehérjéhez hasonlóan tíz NIM domént tartalmaz, míg a Draper fehérje számos EGF doménje mellett csupán egyetlen NIM doménnel rendelkezik. Bár a rekombináns NimB1 fehérje négy NIM domént hordoz, mégis a NimC1-hez hasonló RMFI értékkel köti az E. colit (RMFI=2,639 $\pm 0,554$; $\mathrm{p}=0,009 ; \mathrm{n}=5)$ és a vizsgált Nimród fehérjék közül kizárólag a NimB1 köti a $S$. epidermidis baktériumsejteket (RMFI=2,23 $\pm 0,613 ; \mathrm{p}=0,013 ; \mathrm{n}=5$ ). A másik NimB típusú fehérje, az öt NIM doménnel rendelkező NimB2 a legalacsonyabb RMFI értékkel köti az E. coli baktériumokat (RMFI=1,552 $\pm 0,277 ; \mathrm{p}=0,043 ; \mathrm{n}=5)$, a S. epidermidis sejteket pedig egyáltalán nem (RMFI=1,382 $\pm 0,391 ; p=0,165 ; n=5)$. A NimB típusú fehérjék különböző ligandokat is felismerhetnek, ami feltehetően azért van mert a génklaszter kialakulásakor az egyetlen $\operatorname{nim} B$ gén duplikációi során létrejött $\operatorname{nim} B$ gének funkciói is elkülönültek egymástól.
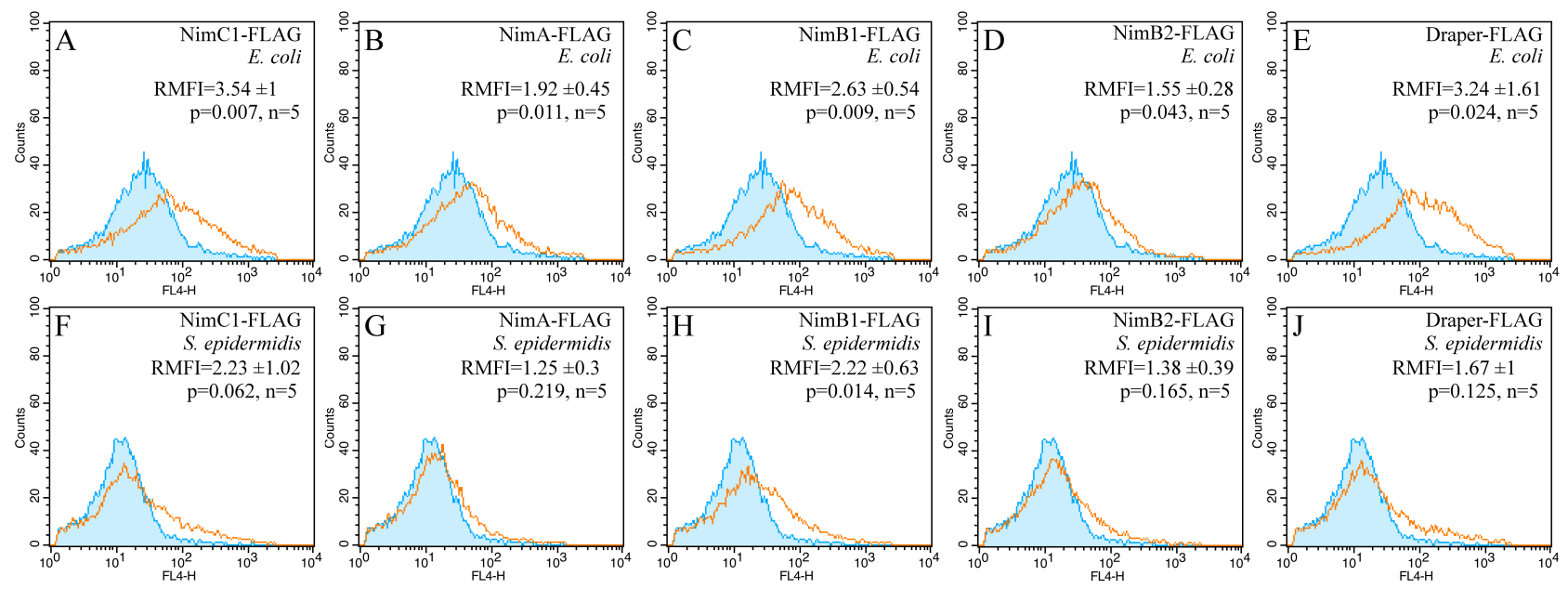

27. ábra: A rekombináns Nimród fehérjék baktériumkötése

A hisztogrammok az egyes rekombináns fehérjéket kifejezö Sf9 sejtlizátumokkal kezelt FITCjelölt E. coli $(A-E)$ és a FITC-jelölt S. epidermidis (F-J) baktériumsejtek fluoreszcencia intenzitását mutatják a távoli vörös tartományban. A rekombináns NimC1 (A, F okkersárga), NimA (B, $G$ okkersárga), NimB1 (C,H okkersárga), NimB2 (D, I okkersárga), Draper (E, J okkersárga) fehérjékhez a FLAG epitóp taggel kiegészitett rekombináns Atilla fehérjét kifejezö Sf9 sejtek lizátuma szolgált negatív kontrollként (A-J kék). 


\section{Az eredmények megbeszélése}

A dolgozatban közölt vizsgálatokkal a munkacsoportunk által azonosított Nimród fehérje- és géncsalád tagjainak a fagocitózisban betöltött szerepét kívántuk megismerni. Megvizsgáltuk a nimród gének kifejeződését az ecetmuslica egyedfejlődése során. Reverz transzkripció kapcsolt polimeráz láncreakcióval mértük az egyes nimród gének kifejeződését. Azt tapasztaltuk, hogy a $\operatorname{nim} A, \operatorname{nim} B$ és $\operatorname{nim} C$ gének az első, második és harmadik lárvastádiumban, valamint az imágókban is kifejeződnek, azonban az izolált hemocitákban kizárólag a nimB és nim $C$ gének mutattak transzkripciós aktivitást, a nimA gén a lárva valamely másik szövetében fejezödik ki, hemocitákban nem nyilvánul meg.

Mivel az ecetmuslica genom öt NimB és négy NimC típusú receptort kódol, valamint a NimC típusú, ám a klaszteren kívül található Eater molekulát, feltételezhető, hogy ezen fehérjék legalább részben átfedő müködésüek ezért, egy-egy NimB vagy NimC fehérje hiánya nem okoz nagy mértékü fenotípusos változást, így a hagyományos funkcióvesztéses mutánsok létrehozásán alapuló genetikai analízis ebben az esetben nem kecsegtetett sikerrel.

Irodalmi adatokból ismert, hogy a fagocitózis receptorok általában jelátviteli folyamatokban is részt vesznek, nagyrészt RNS inhibícióval létrehozott funkcióvesztéses mutánsaik pleiotróp fenotípust mutattak. A Draper fehérjéről, amelyet eredetileg apoptotikus sejtek receptoraként írtak le (Manaka és mtsai., 2004; Kuraishi és mtsai., 2009; MacDonald és mtsai., 2006) később azt is belátták, hogy baktériumok fagocitózisában (Hashimoto és mtsai., 2009; Cuttell és mtsai., 2008), az axonfejlödésben (Awasaki és mtsai., 2006), az autofágiában is szerepet játszik (McPhee és Baehrecke, 2010), azaz egyetlen fehérje hiánya számos különböző folyamatot érinthet. A nimród génklaszter által kódolt fehérjék receptor funkciójának tanulmányozására a fehérjék baktériumokkal létrehozott kölcsönhatásainak in vitro vizsgálata különösen alkalmas, mert egyszerre küszöböli ki az esetleges átfedő müködésű fehérjékből és a funkcióvesztéses mutánsok pleiotróp fenotípusaiból eredő bizonytalanságot. 
Eredményeink szerint a NimC1 fehérje szerepet játszik a fagocitózis folyamatában, hiszen hiányában csökken a hemociták fagocitáló képessége és a NimC1 receptort ki nem fejezö S2 sejtvonalban túltermeltetése növeli a fagocitózis hatékonyságát (Kurucz és mtsai., 2007). Annak megválaszolására, hogy a NimC1 fehérje a fagocitózis folyamatában receptorként funkcionál elsőként a hemociták által kifejezett NimC1 fehérje kölcsönhatását vizsgáltuk különböző Grampozitív és Gram-negatív baktériumokkal. A NimC1 fehérje baktériumsejtekkel kialakított kölcsönhatását indirekt immunfluoreszcenciás festődést követő áramlási citometriával mutattuk ki. Eredményeink szerint a NimC1 fehérje a Gram-negatív E. coli, S. marcescens, $X$. campestris és $P$. aeruginosa, illetve a Gram-pozitív Bacillus cereus var. mycoides baktériumokhoz kötődik, míg a Gram-pozitív S. epidermidis, M. luteus és B. subtilis baktériumokat nem köti. Eredményeink szerint a NimC1 fehérje egyaránt kötődik az erősen patogén $S$. marcescens és a $P$. aeruginosa baktériumokhoz melyek szeptikus sérülés esetén a $D$. melanogaster egyedek túlnyomó többségét egy napon belül elpusztítják (Lemaitre és Hoffmann 2007), és a gazdaszervezet számára veszélytelen E. coli-hoz.

Meglepőnek tünhet, hogy a NimC1 a vizsgált Gram-negatív szervezeteket hasonlóan köti, míg a vizsgált Gram-pozitív szervezeteket különbözőképpen, ám a két mikróbacsoport Gram festés alapján történő elkülönítése nem eredményez homogén csoportokat, nem jelenthető ki egyértelmüen, hogy a minden Gram-pozitív baktérium sejtfala azonos szerkezetü és összetételü. Például ismert, hogy a Gram-negatív szervezetek peptidoglikánjában általában diaminopimelinsavat tartalmazó tetrapeptid keresztköti az N-acetil-glükózaminból és N-acetil-muraminsavból álló cukormolekulákat, míg a Gram-pozitív szervezetekben L-lizin tartalmú tetrapeptidek találhatóak meg. Ám ismert, hogy a B. cereus és a B. subtilis szervezetek, bár a Gram festés alapján Grampozitívnak számítanak, a peptidoglikánjukban diaminopimelinsavat tartalmazó peptidek találhatóak, így ebből a szempontból jobban hasonlítanak a Gram-negatív szervezetekre, mint a Gram-pozitív $S$. epidermidisre (Reith és Mayer 2011).

A NimC1 molekula ligandjának azonosítása érdekében baktériumsejteken kompetíciós kísérleteket végeztünk. Eredményeink szerint a hemocita lizátumhoz adott $E$. coli lizátum gátolja a NimC1 baktériumkötését, ám a baktérium falának két fő komponense, a peptidoglikán és a lipopoliszaccharid nem kompetál a NimC1 kötőhelyével, ami azt mutatja, hogy ezek a molekulák nem ligandjai a NimC1 fehérjének. A fehérjementesített baktérium lizátummal végzett kompetíciós kísérlet során azt tapasztaltuk, hogy az nem gátolja a NimC1 baktériumkötését, amiből arra következtettünk, hogy a NimC1 ligandja fehérjetermészetü. Ez nem meglepő, hiszen a Draper 
molekula egyik ligandja szintén egy fehérjemolekula, a Pretaporter, amely a sejtek felszínén az apoptózis során jelenik meg, míg az életképes sejtek felületén nem nyilvánul meg (Kuraishi és mtsai., 2009). Bár D. melanogasterben nem írtak még le olyan fagocitózis receptort, amely bakteriális fehérjét ismerne fel, gerincesekben több mintázatfelismerő receptort is ismerünk amelyek mikróbákból származó fehérje ligandot ismernek föl. Például az emberi TLR-2 receptor ligandja két, az E. coli sejtfalába integrálódó lipoprotein, a Lip 19 és a Lip12 (Lee és mtsai., 2002). Az emberi TLR-5 ligandja a bakteriális Flagellin (Gewirtz és mtsai., 2001), a TLR-4 fehérje egyik ligandja az E. coli FimH fehérjéje, amely a baktérium fimbriumainak alkotóeleme (Mossmann és mtsai., 2008), míg az emberi TLR-11 és TLR-12 receptorok a Toxoplasma gondii Profilin fehérjéjét ismerik fel (Koblansky és mtsai., 2013; Yarovinsky és mtsai., 2005).

A hemociták által kifejezett NimC1 molekula baktérium kötését a fehérjét specifikusan felismerő két monoklonális ellenanyag keverékével mutattuk ki. Mivel a NimA, NimB1-5 és NimC2-4 fehérjéket felismerő ellenanyagokkal nem rendelkezünk, e fehérjék baktériumkötési képességének vizsgálatához rekombináns fehérjeként fejeztettük ki a NimA, NimB1, NimB2, NimC1 és kontrollként a Draper fehérjék extracelluláris doménjét melyet egy FLAG epitóp taggel egészítettük ki. A FLAG epitópot specifikusan felismerő ellenanyag segítségével határoztuk meg a rekombináns fehérjék baktériumkötő képességét. Elsőként összehasonlítottuk a rekombináns NimC1 baktériumkötő képességét a NimC1 fehérjét felismerő P1a, P1b ellenanyagunk és a FLAG epitópot felismerő ellenanyag alkalmazásával. Azt találtuk, hogy a két rendszerben hasonló a rekombináns NimC1 E. coli baktériumhoz kötése, ezért a rekombináns fehérjék baktériumkötésének FLAG epitóp segítségével történő meghatározása megbízható mérőrendszernek bizonyult. Meghatároztuk a NimA, NimB1, NimB2 és a Draper fehérjék baktériumkötési képességét is, és azt tapasztaltuk, hogy mindegyik vizsgált fehérje kötődik E. coli baktériumokhoz, míg S. epidermidis baktériumsejtekhez kizárólag a NimB1 fehérje kötődött.

Ezekkel a vizsgálatainkkal kibővítettük az eddig ismert Drosophila melanogaster fagocitózis receptorok körét és a harmadik táblázatban újra összefoglaltuk a mikróbák felismerésében szerepet játszó ecetmuslica fehérjéket. 
3. táblázat: Az egyes Drosophila melanogaster fagocitózis receptorok ismert ligandjai (NA=nincs adat)

\begin{tabular}{|c|c|c|c|c|}
\hline Receptor & $\begin{array}{l}\text { Gram-negatív } \\
\text { baktérium }\end{array}$ & $\begin{array}{l}\text { Gram-pozitív } \\
\text { baktérium }\end{array}$ & gomba & apoptotikus sejt \\
\hline dSR-CI & + & + & NA & NA \\
\hline PGRP-LC & + & - & NA & NA \\
\hline MCR/TEP6 & - & NA & + & NA \\
\hline TEPII & + & - & - & NA \\
\hline TEPIII & - & + & - & NA \\
\hline Peste & + & + & NA & NA \\
\hline Croquemort & + & + & NA & + \\
\hline Dscam & + & NA & NA & NA \\
\hline NPC2a, 2e, 2h & $+?$ & $+?$ & NA & NA \\
\hline NimC4/Simu & NA & NA & NA & + \\
\hline Draper & + & + & NA & + \\
\hline Eater & + & + & NA & NA \\
\hline NimA & + & - & NA & NA \\
\hline NimB1 & + & + & NA & NA \\
\hline NimB2 & + & - & NA & NA \\
\hline NimC1 & + & - & NA & NA \\
\hline
\end{tabular}

Rekombináns fehérjék előállításával in vitro körülmények között vizsgáltuk meg a Nimród fehérjecsalád kiválasztott tagjainak baktériumkötési képességét. Eredményeink szerint a Nimród fehérje- és géncsalád tagjai a fagocitózisban receptor funkcióval bírnak. A transzmembrán doménnel rendelkező NimC fehérjék valószínüleg fagocitózis receptorként müködnek, a mikróbák érzékelésében és a sejthez rögzítésében játszanak szerepet. A transzmembrán doménnel nem rendelkező NimB fehérjék a hemolimfában oldott opszoninként müködhetnek, a mikróbák felszínéhez kötődve segítik azok bekebelezését.

Az általunk vizsgált Nimród fehérjék minden bizonnyal kisebb affinitással kötődnek az $E$. coli baktériumokhoz, mint az Eater fehérje, amelynek a baktériumkötéséről részletes adatokkal rendelkezünk (Kocks és Chung 2011). Ennek a magyarázata az lehet, hogy evolúciósan előnyösnek bizonyulhat, ha egy szervezet több alacsony affinitású receptorral ismeri fel a baktériumsejteket, mivel a ligand, ez esetben a baktérium, a gazdaszervezetnél jóval gyorsabban szaporodik. Amennyiben egyetlen receptor felelös a mikróba felismeréséért, könnyebben szaporodnak el olyan mutánsok, amelyek a receptor ligandjának egy eltérő változatát fejezik ki, így könnyen elkerülhetik 
a gazdaszervezet immunválaszát. Amennyiben a mikróbát több különböző, kis affinitású receptorfehérje ismeri fel, egyetlen fehérje ligandjának megváltozása nem juttatja döntő előnyhöz a baktériumot a gazdaszervezettel szemben és ezeknek a mutánsoknak az életképessége kevésbé különbözik a vad típusú egyedekétől, ezért egy ilyen mutáció sokkal nehezebben rögzül a populációban. Ez lehet a magyarázata annak, hogy miért kódol a D. melanogaster genom öt nimB és négy nimC gént, az eater mellett, hiszen könnyen lehetséges, hogy az evolúció folyamán előnyösebb, ha a szervezet a kórokozókat több alacsony affinitású receptorral ismeri fel, mintha egyetlen magas affinitású receptorral szál szembe a gazdaszervezetet veszélyeztető mikroorganizmusokkal. 


\section{Köszönetnyilvánítás}

Köszönettel tartozom témavezetőmnek, Dr. Kurucz Évának, munkacsoportunk vezetőjének Dr. Andó Istvánnak, munkatársaimnak, Dr. Bajusz Izabellának, Pintér Lajosnak, Dr. Márkus Róbertnek, Dr. Lukacsovich Tamásnak, Dr. Cinege Gyöngyinek, Dr. Honti Viktornak, Csordás Gábornak, Váczi Balázsnak, Dr. Laurinyecz Barbarának, Kari Beátának. Köszönöm a munkáját a házivédés opponenseinek Dr. Jankovics Ferencnek és Dr. Vizler Csabának. Tanácsaival, iránymutatásaival rengeteget segített Dr. Udvardy Andor, Dr. Mihály József, Dr. Sipos László, Dr. Gyurkovics Henrik, Dr. Blazsó Péter és a Genetikai Intézet közösségének minden tagja.

Köszönöm a támogatásukat, gondoskodásukat szüleimnek, Dr. Zsámboki Jánosnak és Dr. Fórizs Annának, testvéremnek, Dr. Zsámboki Annának, feleségemnek, Németh Erikának és kisfiamnak, Zsámboki Botondnak. 


\section{Hivatkozott közlemények}

Asha H, Nagy I, Kovács G, Stetson D, Andó I, Dearolf CR (2003) Analysis of Ras-induced overproliferation in Drosophila hemocytes. Genetics 163(1), 203-15.

Awasaki T, Tatsumi R, Takahashi K, Arai K, Nakanishi Y, Ueda R, Ito K (2006) Essential role of the apoptotic cell engulfment genes draper and ced-6 in programmed axon pruning during Drosophila metamorphosis Neuron 50(6), 855-67.

Baba T, Ara T, Hasegawa M, Takai Y, Okumura Y, Baba M, Datsenko KA, Tomita M, Wanner BL, Mori H (2006) Construction of Escherichia coli K-12 in-frame, single-gene knockout mutants: the Keio collection. Mol Syst Biol 2,1-11

Bhutkar, A., Schaeffer, S.W., Russo, S.M., Xu, M., Smith, T.F. and Gelbart, W.M., (2008)

Chromosomal rearrangement inferred from comparisons of 12 Drosophila genomes. Genetics 179, 1657-1680.

Blom, N., Gammeltoft, S., and Brunak, S., 1999. Sequence- and structure-based prediction of eukaryotic protein phosphorylation sites. J. Mol. Biol. 294, 1351-1362.

Callebaut I, Mignotte V, Souchet M, Mornon JP., 2003. EMI domains are widespread and reveal the probable orthologs of the Caenorhabditis elegans CED-1 protein. Biochem Biophys Res Commun. 300:619-623.

Chamaillard M, Hashimoto M, Horie Y, Masumoto J, Qiu S, Saab L, Ogura Y, Kawasaki A, Fukase K, Kusumoto S, Valvano MA, Foster SJ, Mak TW, Nuñez G, Inohara N (2003) An essential role for NOD1 in host recognition of bacterial peptidoglycan containing diaminopimelic acid. Nature Immunology 4(7), 702-7.

Chen L, Coleman WG Jr (1993) Cloning and characterization of the Escherichia coli K-12 rfa-2 (rfaC) gene, a gene required for lipopolysaccharide inner core synthesis. Journal of Bacteriology 175(9), 2534-40.

Chung YA, Kocks C (2011) Recognition of pathogenic microbes by the Drosophila phagocytic pattern recognition receptor Eater. Journal of Biological Chemistry 286(30), 26524-32.

Cuttell, L, Vaughan A, Silva E, Escaron CJ, Lavine M, Van Goethem E, Eid JP, Quirin M, Franc NC (2008) Undertaker, a Drosophila junctophilin, links Draper-mediated phagocytosis and calcium homeostasis. Cell 135:524-534.

Evans CJ, Hartenstein V, Banerjee U (2003) Thicker than blood: conserved mechanisms in Drosophila and vertebrate hematopoiesis. Dev Cell. 5:673-90. 
Gateff E., Malignant neoplasms of the hematopoietic system in three mutants of Drosophila melanogaster. Ann Parasitol Hum Comp. 1977 52:81-3.

Gewirtz AT, Navas TA, Lyons S, Godowski PJ, Madara JL (2001) Cutting Edge: Bacterial Flagellin Activates Basolaterally Expressed TLR5 to Induce Epithelial Proinflammatory Gene Expression. J Immunol 167:1882-1885

Goto, A., Kadowaki, T., Kitagawa, Y., 2003. Drosophila hemolectin gene is expressed in embryonic and larval hemocytes and its knock down causes bleeding defects. Dev. Biol. 264, 582-591. Hamon Y, Trompier D, Ma Z, Venegas V, Pophillat M, et al (2006) Cooperation between Engulfment Receptors: The Case of ABCA1 and

MEGF10. PLoS ONE 1(1): e120. doi:10.1371/journal.pone.0000120

Hashimoto Y, Tabuchi Y, Sakurai K, Kutsuna M, Kurokawa K, Awasaki T, Sekimizu K, Nakanishi Y, Shiratsuchi A (2009) Identification of lipoteichoic acid as a ligand for draper in the phagocytosis of Staphylococcus aureus by Drosophila hemocytes; J Immunol. 183(11), 7451-60 Haskins KA, Russell JF, Gaddis N, Dressman HK, Aballay A (2008) Unfolded protein response genes regulated by CED-1 are required for Caenorhabditis elegans innate immunity. Developmental cell 15(1), 87-97.

Heinrichs DE, Yethon JA, Whitfield C (1998) Molecular basis for structural diversity in the core regions of the lipopolysaccharides of Escherichia coli and Salmonella enterica. Molecular Microbiology 30(2), 221-232

Herboso L., Talamillo A., Pérez C., Barrio R., 2011. Expression of the Scavenger Receptor Class B type I (SR-BI) family in Drosophila melanogaster. Int. J. Dev. Biol. 55: 603-611 Hirschfeld M, Ma Y, Weis JH, Vogel SN, Weis JJ (2000) Cutting edge: repurification of lipopolysaccharide eliminates signaling through both human and murine toll-like receptor 2 . Journal of Immunology 165(2), 618-22.

Honti V, Kurucz E, Csordás G, Laurinyecz B, Márkus R, Andó I (2009) In vivo detection of lamellocytes in Drosophila melanogaster. Immunology Letters 126(1-2), 83-4.

Jin X, Ha TS, Smith DP. 2008. SNMP is a signaling component required for pheromone sensitivity in Drosophila. PNAS 105:10996-1001.

Koblansky AA, Jankovic D, Oh H, Hieny S, Sungnak W, Mathur R, Hayden MS, Akira S, Sher A, Ghosh S (2013) Recognition of profilin by Toll-like receptor 12 is critical for host resistance to Toxoplasma gondii. Immunity. 38:119-30. 
Kocks, C., Cho, J.H., Nehme, N., Ulvila, J., Pearson, A.M., Meister, M., Strom, C., Conto, S.L., Hetru, C., Stuart, L.M., Stehle, T., Hoffmann, J.A., Reichhart, J., Ferrandon, D., Rämet, M., Ezekowitz, R.A.B., 2005. Eater, a transmembrane protein mediating phagocytosis of bacterial pathogens in Drosophila. Cell 123, 335-346.

Konrad, L., Becker, G., Schmidt, A., Klockner, T., Kaufer-Stillger, G., Dreschers, S., Edström, J.E., Gateff, E., 1994. Cloning, structure, cellular localization, and possible function of the tumor suppressor gene lethal(3)malignant blood neoplasm-1 of Drosophila melanogaster. Dev. biol. 163, 98-111.

Kuan S, Rust K, Crouch E (1992) Interactions of Surfactant Protein D with Bacterial Lipopolysaccharides. The Journal of Clinical Investigation 90, 97-106

Kuraishi T, Nakagawa Y, Nagaosa K, Hashimoto Y, Ishimoto T, Moki T, Fujita Y, Nakayama H, Dohmae N, Shiratsuchi A, Yamamoto N, Ueda K, Yamaguchi M, Awasaki T, Nakanishi Y (2009) Pretaporter, a Drosophila protein serving as a ligand for Draper in the phagocytosis of apoptotic cells. EMBO J 28(24), 3868-78.

Kurant E, Axelrod S, Leaman D, Gaul U (2008) Six-microns-under acts upstream of Draper in the glial phagocytosis of apoptotic neurons. Cell 133(3), 498-509.

Kurucz E, Váczi B, Márkus R, Laurinyecz B, Vilmos P, Zsámboki J, Csorba K, Gateff E, Hultmark D, Andó I (2007a) Definition of Drosophila hemocyte subsets by cell-type specific antigens. Acta Biologica Hungarica 58 Suppl, 95-111

Kurucz E, Zettervall CJ, Sinka R, Vilmos P, Pivarcsi A, Ekengren S, Hegedüs Z, Ando I, Hultmark D (2003) Hemese, a hemocyte-specific transmembrane protein, affects the cellular immune response in Drosophila. PNAS 100(5), 2622-7.

Kurucz, E., Márkus, R., Zsámboki, J., Folkl-Medzihradszky, K., Darula, Z., Vilmos, P., Udvardy, A., Krausz, I., Lukacsovich, T., Gateff, E., Zettervall, C.J., Hultmark, D., Andó, I., (2007b) Nimrod, a putative phagocytosis receptor with EGF repeats in Drosophila plasmatocytes. Curr. Biol. 17, 649-54.

Lee HK, Lee J, Tobias PS (2002)Two lipoproteins extracted from Escherichia coli K-12 LCD25 lipopolysaccharide are the major components responsible for Toll-like receptor 2-mediated signaling. J Immunol. 168:4012-4017.

Lemaitre B, Hoffmann J (2007) The host defense of Drosophila melanogaster. Annu Rev Immunol. 25:697-743. 
MacDonald JM, Beach MG, Porpiglia E, Sheehan AE, Watts RJ, Freeman MR (2006) The Drosophila cell corpse engulfment receptor Draper mediates glial clearance of severed axons. Neuron 50(6), 869-81.

Manaka, J., Kuraishi, T., Shiratsuchi, A., Nakai, Y., Higashida, H., Henson, P., Nakanishi, Y., 2004. Draper-mediated and phosphatidylserine-independent phagocytosis of apoptotic cells by Drosophila hemocytes/macrophages. J. Biol. Chem. 279, 48466-48476.

Markovic I, Pulyaeva H, Sokoloff A, Chernomordik LV (1998) Membrane fusion mediated by baculovirus gp64 involves assembly of stable gp64 trimers into multiprotein aggregates. Journal of Cell Biology143(5), 1155-66.

McPhee CK, Baehrecke EH (2010) The engulfment receptor Draper is required for autophagy during cell death. Autophagy.6(8), 1192-3.

Means TK, Mylonakis E, Tampakakis E, Colvin RA, Seung E, Puckett L, Tai MF, Stewart CR, Pukkila-Worley R, Hickman SE, Moore KJ, Calderwood SB, Hacohen N, Luster AD, El Khoury J (2009) Evolutionarily conserved recognition and innate immunity to fungal pathogens by the scavenger receptors SCARF1 and CD36. The Journal of Experimental medicine 206(3), 637-53. Mossman KL, Mian MF, Lauzon NL, Gyles CL, Lichty B, Mackenzie R, Gill N, Ashkar AA (2008) Cutting Edge: FimH Adhesin of Type 1 Fimbriae Is a Novel TLR4 Ligand. J Immunol 181:67026706.

Pak WL, Shino S, Leung HT. 2012. PDA (prolonged depolarizing afterpotential)-defective mutants: the story of nina's and ina's--pinta and santa maria, too. J Neurogenet. 26:216-37.

Pearson A., Lux A., Krieger M., 1995. Expression cloning of dSR-CI, a class C macrophagespecific scavenger receptor from Drosophila melanogaster. PNAS 92: 4056-4060

Peiser L., Mukhopadhyay S., Gordon S., 2002. Scavanger receptors in innate immunity. Curr. Op. Immun. 14, 123-128.

Qimron U, Marintcheva B, Tabor S, Richardson CC (2006) Genomewide screens for Escherichia coli genes affecting growth of T7 bacteriophage. PNAS 103(50), 19039-44.

Reit J, Mayer C (2011) Peptidoglycan turnover and recycling in Gram-positive bacteria. Applied Microbiology and Biotechnology 92:1-11

Ren J, Wen L, Gao X, Jin C, Xue Y, Yao X. 2008. DOG 1.0: Illustrator of Protein Domain Structures. Cell Research 19:271-273. 
Shi, X.Z., Zhong, X., Yu, X.Q., 2012. Drosophila melanogaster NPC2 proteins bind bacterial cell wall components and may function in immune signal pathways. Insect Biochem. Mol. Biol. 42, 545-56.

Somogyi, K, Sipos B, Pénzes Z, Andó I (2010) A conserved gene cluster as a putative functional unit in insect innate immunity. FEBS Letters 584, 4375-4378

Somogyi, K., Sipos, B., Pénzes, Z., Kurucz, E., Zsámboki, J., Hultmark, D., Andó, I., 2008.

Evolution of genes and repeats in the Nimrod superfamily. Molecular Biology and Evolution 25, 2337-2347.

Stroschein-Stevenson, S.L., Foley, E., O’Farrell, P.H., Johnson, A.D., 2006. Identification of Drosophila gene products required for phagocytosis of Candida albicans. PLoS Biol. 4, e4 Stuart, L.M., Deng, J., Silver, J.M., Takahashi, K., Tseng, A.A., Hennessy, E.J., Ezekowitz, R.A., Moore, K.J., 2005a. Response to Staphylococcus aureus requires CD36-mediated phagocytosis triggered by the COOH-terminal cytoplasmic domain. J. Cell Biol. 170, 477-485.

Stuart, L.M., Ezekowitz, R.A., 2005b. Phagocytosis: Elegant complexity. Immunity 22, 539-550. Stuart, L.M., Ezekowitz, R.A., 2008. Phagocytosis and comparative innate immunity: learning on the fly. Nat Rev Immunol. 2, 131-141.

Voolstra O, Kiefer C, Hoehne M, Welsch R, Vogt K, von Lintig J. 2006. The Drosophila class B scavenger receptor NinaD-I is a cell surface receptor mediating carotenoid transport for visual chromophore synthesis. Biochemistry. 45:13429-37.

Watson, F.L., Püttmann-Holgado, R., Thomas, F., Lamar, D.L., Hughes, M., Kondo, M., Rebel, V.I., Schmucker, D., 2005. Extensive diversity of Ig-superfamily proteins in the immune system of insects. Science 309, 1874-1878.

Werner T, Liu G, Kang L, Ekengren S, Steiner H, Hultmark D (2000) A family of peptidoglycan recognition proteins in the fruit fly Drosophila melanogaster. PNAS 97: 13772-13777 Williams MJ (2007) Drosophila hemopoiesis and cellular immunity. J Immunol. 178:4711-6. Wu HH, Bellmunt E, Scheib JL, Venegas V, Burkert C, Reichardt LF, Zhou Z, Fariñas I, Carter BD (2009) Glial precursors clear sensory neuron corpses during development via Jedi-1, an engulfment receptor. Nature Neuroscience 12(12), 1534-41

Wu HH, Bellmunt E, Scheib JL, Venegas V, Burkert C, Reichardt LF, Zhou Z, Fariñas I, Carter BD. Glial precursors clear sensory neuron corpses during development via Jedi-1, an engulfment receptor. Nat Neurosci. 2009 12:1534-41. 
Yarovinsky F, Zhang D, Andersen JF, Bannenberg GL, Serhan CN, Hayden MS, Hieny S, Sutterwala FS, Flavell RA, Ghosh S, Sher A (2005) TLR11 activation of dendritic cells by a protozoan profilin-like protein. Science. 308:1626-9.

Yu X, Lu N, Zhou Z (2008) Phagocytic receptor CED-1 initiates a signaling pathway for degrading engulfed apoptotic cells. PLOS biology 6(3), e61

Zettervall CJ, Anderl I, Williams MJ, Palmer R, Kurucz É, Andó I, Hultmark D (2004) A directed screen for genes involved in Drosophila blood cell activation. Proc. Natl. Acad. Sci. USA 101, 14192-14197.

Zhou Z, Hartwieg E, Horvitz HR (2001) CED-1 is a transmembrane receptor that mediates cell corpse engulfment in C. elegans. Cell 104(1), 43-56. 


\section{Magyar nyelvü összefoglaló}

A fagocitózis folyamata a törzsfejlődés során már az egysejtüekben kialakult, ahol a táplálkozást szolgálja, többsejtü szervezetekben az egyedfejlődés során történő szöveti átrendeződésekben, valamint a kórokozó mikroorganizmusok elleni védekezésben játszik kulcsszerepet. A fagociták, a veleszületett immunválasz végrehajtó sejtjei, sejtfelszíni receptoraik segítségével érzékelik a környezetükben megjelenő testidegen, illetve megváltozott saját struktúrákat. A receptorok ligand-kötése a fagocita sejtekben olyan jelátviteli utakat aktivál, melynek során az aktin sejtváz átrendeződésével a mikroorganizmusokat körülölelő pszeudopódiumok képződnek, majd az így bekebelezett részecskéket a fagoszómákban a hidrolitikus enzimek lebontják.

A fagocitózis molekuláris folyamatainak vizsgálatához a Drosophila melanogaster-t választottuk modellszervezetnek, mivel az ecetmuslica kizárólag a veleszületett immunitás folyamataival biztosítja szervezete homeosztázisát. A Drosophila fagocita sejtjei, a plazmatociták az egyedfejlődés során már az embrióban kialakulnak, itt elsősorban az apoptózissal elpusztuló sejtek eltávolításában, ezen keresztül az idegrendszer fejlődésében játszanak szerepet. A plazmatociták a lárvális és a felnőtt egyedekben az immunvédekezést szolgálva, a szervezetbe jutó testidegen mikroorganizmusok felismerését és bekebelezését végzik.

Korábban a Drosophila melanogaster fagocita sejtjein egy transzmembrán fehérjét azonosítottunk, melynek kódoló génjét nimród-nak (nimC1) neveztük el. A nimC1 gén szekvenciája alapján prediktált fehérje a transzmembrán fehérjékre jellemző szerkezetü, szingál peptiddel, extracelluláris, transzmembrán és intracelluláris régiókkal rendelkezik. A NimC1 fehérje extracelluláris régiójában egy új típusú EGF-receptor domént azonosítottunk, mely az állatvilágban általánosan elterjedt EGF-receptor doménhez képest szigorúbb konszenzusszekvenciával írható le (CxPxCxxxCxNGxCxxPxxCxCxxGY). Ezt az új típusú domént NIM doménnek neveztük el.

A NimC1 fehérje funkciójának vizsgálatát funkcióvesztéses és funkciónyeréses genetikai tesztekben végeztük el. A funkcióvesztéses vizsgálatokban RNS inhibíció módszerrel csökkentettük a NimC1 fehérje kifejeződését, és ezzel együtt a hemociták Staphylococcus aureus baktérium fagocitózisának jelentős csökkenését tapasztaltuk. A funkciónyerési vizsgálathoz a NimC1 fehérjét a NimC1 fehérjét nem expresszáló a Drosophila melanogaster eredetü Schneider-2 sejtvonalban túltermeltettük. A NimC1 molekulának a Schneider-2 sejtek plazmamembránjában történő 
megjelenésével egyidejüleg azt tapasztaltuk, hogy a $S$. aureus és $E$. coli baktériumokat fagocitáló képességük is megnövekedett.

A Drosophila melanogaster genomjában további tizenegy olyan gént azonosítottunk, amelyek a NimC1 fehérjéhez hasonló szerkezetü fehérjéket kódolnak. A NimC1 szerkezeti homológok mindegyike tartalmaz legalább egy NIM domént, valamint az N-terminális NIM domént megelőző CCxGY motívumot. A NimC1 homológokat kódoló gének a Drosophila melanogaster második kromoszómáján, a nimC1 gén közvetlen genomi környezetében, géncsaládot (nimród géncsalád) alkotva helyezkednek el. A nimród géncsalád által kódolt fehérjéket szerkezetük alapján három kategóriába soroltuk. A NimA fehérje egyetlen NIM domént tartalmazó transzmembrán molekula. A NimB típusú fehérjék transzmembrán régióval nem rendelkező, 1-7 NIM domént tartalmazó molekulák, a NimC típusú fehérjék 2-16 NIM domént tartalmazó transzmembrán fehérjék.

Az ecetmuslica genom további NIM doménnel rendelkező fehérjéket is kódol: Az embrionális makrofágok apoptózisában szerepet játszó Draper fehérjét, valamint a fagocita sejtek baktérium kötésében résztvevő Eater molekulát.

A nimród géncsalád kifejeződését reverz transzkripcióhoz kapcsolt polimeráz láncreakcióval vizsgáltuk. Megállapítottuk, hogy, a $\operatorname{nim} A, \operatorname{nim} B 1, \operatorname{nimB2}, \operatorname{nim} B 3, \operatorname{nim} B 4, \operatorname{nim} B 5, \operatorname{nim} C 1, \operatorname{nim} C 2$, nimC3 és nimC4 génekről mindhárom lárva stádiumban az imágókban, valamint a harmadik stádiumú lárvák vérsejtjeiben szintetizálódik RNS molekula, a nimA gén kivételével, amely a harmadik stádiumú lárvák hemocitáiban nem fejeződik ki.

A NimC1 fehérje funkcióját baktériumkötési kísérletekkel vizsgáltuk. Hővel elölt baktériumsejteket fluorescein isothiocyanate-tal (FITC) jelöltük, majd a NimC1 fehérjét kifejező hemociták lizátumával kezeltük. A FITC-el jelzett baktériumokhoz kötődő NimC1 molekulát indirekt immunfluoreszcencia módszerrel távoli vörös tartományban emittáló fluoreszcens festékkel megjelöltük és áramlási citometriával vizsgáltuk. Eredményeink szerint a NimC1 specifikus ellenanyaggal festett Escherichia coli baktériumok fluoreszcencia intenzitása a távoli vörös tartományban több mint kétszeresére emelkedett a kontrolként használt immunglobulin izotípus kontroll ellenanyaggal festett baktériumsejtekéhez képest, ami azt jelenti, hogy a NimC1 fehérje kötődik az E. coli baktériumsejtekhez. Vizsgálataink szerint a NimC1 fehérje az E. coli baktériumon kívül kötődik még a Serratia marcescens, Xanthomonas campestris, Pseudomonas aeruginosa Gram-negatív és a Bacillus cereus var. mycoides Gram-pozitív baktériumokhoz, viszont a Grampozitív Staphylococcus epidermidis, Micrococcus luteus és Bacillus subtilis baktériumokat nem köti. 
Az E. coli baktériumsejteken a NimC1 fehérjét kötő molekulát kompetíciós kísérletekkel kívántuk azonosítani. A NimC1 molekulát kifejező hemociták lizátumához adott lipopoliszaccharid és peptidoglikán nem befolyásolja a NimC1 fehérjének az E. coli baktériumhoz történő kötődését, így ezek a molekulák nem lehetnek a NimC1 receptor ligandjai.

További vizsgálataink során azt tapasztaltuk, hogy az E. coli sejtekből készült lizátum valamely komponense erősen gátolja a NimC1 molekulának az E. coli sejtekhez történő kötődését. Mivel a fenolprecipitálással illetve Proteináz K enzimkezeléssel fehérjementesített E. coli lizátum már nem gátolta a NimC1 baktériumkötését, ebből a kísérletből arra következtettünk, hogy az $E$. coli sejteken megnyilvánuló, NimC1-t kötő molekula fehérje természetü.

A nimród géncsalád által kódolt fehérjék közül a NimA, NimB1, NimB2 és NimC1 fehérjék extracelluláris doménjét FLAG epitóppal ellátott rekombináns fehérjeként fejeztettük ki baculovírus expressziós rendszerben. A rekombináns fehérjéket termelő Sf9 lepke sejtvonal lizátumával baktériumkötési kísérletet végeztünk, elsődleges ellenanyagként a FLAG epitópot felismerő monoklonális ellenanyagot használtunk, majd a baktériumsejtek fluoreszcenciájának intenzitását áramlási citometriával határoztuk meg. Pozitív kontrollként a D. melanogaster Draper molekulát, negatív kontrollként egy, a hemocitákon kifejeződő, NIM domént nem tartalmazó fehérjét, az Atilla molekulát fejeztettük ki. Eredményeink szerint a rekombináns NimA, NimB1, NimB2, NimC1, és Draper molekulák kötődtek E. coli baktériumokhoz, azonban a S. epidermidis baktériumsejtekhez kizárólag a NimB1 kötődött. 


\section{Summary}

The process of phagocytosis has evolved early in life, in unicellular eukaryotic organisms, where it is utilized for feeding. In multicellular organisms the main immune function of phagocytosis is the defence against pathogenic microbes and the elimination of apoptotic cells during histological reorganizations through ontogenesis. Professional phagocytes, the effector cells of the innate immune response sense the foreign or altered self particles appearing in their environment by their cell surface receptors. The ligand binding of these receptors induces signal transduction pathways which reorganize the actin cytoskeleton, and the cell grows pseudopodia, to engulf the target particle, which is lysed in the hydrolytic enzymes of the phagosome.

We chose Drosophila melanogaster to study the molecular processes of phagocytosis, because the fruit fly relies only on innate immune processes to maintain its homeostasis. The phagocytes of Drosophila, the plasmatocytes differentiate early in ontogenesis, in the embryo, where their main function is the elimination of apoptotic cells in the developing nervous system. Plasmatocytes recognize and engulf foreign particles in the larva and in the adult.

Previously we have identified a transmembrane protein on the plasmatocytes of $D$. melanogaster, which we named Nimród and its coding gene nimród (nimC1). Inferring from the sequence of the gene the predicted $\mathrm{NimC1}$ protein shows a domain structure typical of a transmembrane protein, harboring a signal peptide, extracellular, transmembrane and intracellular regions. In the extracellular domain of $\mathrm{NimC} 1$ we identified a new subclass of the EGF-receptor domain, which can be characterized with the consensus sequence

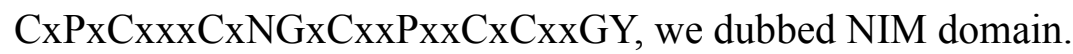

We studied the function of the NimC1 protein in loss-of-function and gain-of-function genetic tests. In the loss-of-function studies we inhibited the expression of NimC1 by RNAi, and by decreasing the amount of $\mathrm{NimC1}$ on the surface of hemocytes, their Staphylococcus aureus phagocytic capacity also decreased. For the gain-of-function studies we expressed the NimC1 protein in the Schneider-2 cell line which does not express NimC1. The occurrence of NimC1 in the membrane of Schneider-2 cells the $S$. aureus and Escherichia coli phagocytic capacity of the cells increased.

We identified eleven genes in the D. melanogaster genome coding proteins with similar domain structure. All eleven proteins harbor at least one NIM domain, and a CCxGY motif preceding the first NIM domain. Nine from these eleven genes are located in the direct genomic 
vicinity of the nimCl gene, constituting the nimród gene family located on the second chromosome. The proteins encoded by the nimród gene family can be divided into three different types. The NimA protein harbors a single NIM domain and a transmembrane domain. The NimB-type proteins harbor 1-7 NIM domains, but lack a transmembrane domain, and the NimC-type proteins harbor 216 NIM domains and a transmembrane domain. The fruit fly genome encodes two NIM domain containing proteins, the Draper which plays a role in the phagocytosis of apoptotic cells and the Eater protein involved in bacterium binding.

We studied the expression of the nimród gene family by reverse transcription coulpled polymerase chain reaction. We found that the $\operatorname{nim} A, \operatorname{nim} B 1, \operatorname{nim} B 2, \operatorname{nim} B 3, \operatorname{nim} B 4, \operatorname{nim} B 5, \operatorname{nim} C 1$, $\operatorname{nim} C 2$, nim $C 3$ and nim $C 4$ genes are transcribed in all three larval stages and in the imago. In the isolated hemocytes of third instar larvae $\operatorname{nim} B 1, \operatorname{nim} B 2, \operatorname{nim} B 3, \operatorname{nim} B 4, \operatorname{nim} B 5, \operatorname{nim} C 1, \operatorname{nim} C 2$, nim $C 3$ and nim $C 4$ genes show transcriptional activity, while nimA is not expressed.

To study the function of the NimC1 protein we conducted bacterium binding experiments . Heat inactivated, fluorescein isothiocyanate (FITC) labeled bacterial cells were incubated in the lysate of hemocytes expressing NimC1. The NimC1 molecule forming a complex with the labelled bacterial cells were stained by indirect immunfluorescence in the far-red spectrum and measured by flow cytometry. According to our results the far-red fluorescence of the E. coli cells treated with hemocyte lysate and stained with NimC1-specific antibodies increased more than twofold compared to the controll particles stained with isotype specific control antibodies, showing that the NimC1 proteind binds E. coli bacteria. The NimC1 protein binds Serratia marcescens, Xanthomonas campestris, Pseudomonas aeruginosa Gram-negative and the Bacillus cereus var. mycoides Grampositive bacteria, while does not show binding to Gram-positive Staphylococcus epidermidis, Micrococcus luteus and Bacillus subtilis.

We intended to identify the ligand of $\mathrm{NimC} 1$ on bacterial cells by competition experiments. We supplemented the lysate of NimC1 expressing hemocytes with lipopolisaccharide and peptidoglican, neither of wich competed for NimC1 binding, showing that neither of them serves as the ligand of $\mathrm{NimC} 1$.

In our experiments we found that the lysate of E. coli cells effectively inhibits NimC1 binding. As the phenol precipitated and Proteinase $\mathrm{K}$ degraded protein-free E. coli lysates do not inhibit NimC1 binding, we concluded that the ligand of $\mathrm{NimC} 1$ is a protein.

We expressed the extraellular domains of NimA, NimB1, NimB2 and NimC1 in a baculovirus-based eukaryotic expression system as recombinant proteins with a FLAG epitope tag. 
We conducted bacterium binding experiments with the lysate of the lepidopteran Sf9 cell line expressing the recombinant proteins, using the monoclonal antibody recognising the FLAG epitope as the primary antibody, and measured the fluorescence intensity of the bacteria with flow cytometry. As a positive control, we expressed the Draper protein, as a negative control, we expressed the Atilla protein, which is expressed on the non-phagocytic lamellocytes and does not contain NIM domains. According to our results the recombinant NimA, NimB1, NimB2, NimC1, and Draper bind E. coli bacteria, while only NimB1 bound S. epidermidis.

65. oldal 